Fernanda Marcello de Oliveira

\title{
Changes in the South Atlantic Subtropical Gyre circulation from the 20th into the 21st century
}

\begin{abstract}
Master thesis submitted to Instituto Oceanográfico of Universidade de São Paulo in partial fulfillment of the requirements for the degree of Master of Science in Oceanography, with emphasis in Physical Oceanography.
\end{abstract}

Advisor:

Prof. ${ }^{a}$ Dr. ${ }^{a}$ llana Wainer

São Paulo 
Whatever discipline you are in...

Do what only you can do best.

Make good art.

$\sim$ Neil Gaiman 


\section{Contents}

Acknowledgements

Abstract viii

Resumo ix

List of Figures $\quad$ x

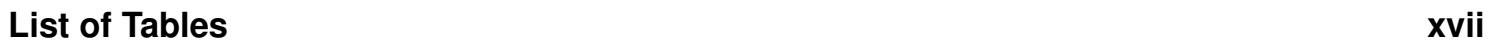

List of Abbreviations $\quad$ xviii

1 Introduction 1

1.1 Subtropical gyres and climate variability $\ldots \ldots \ldots \ldots$

1.2 The South Atlantic Subtropical Gyre and the sSEC Bifurcation . . . . . . . . 2

1.3 Scientific Hypothesis . . . . . . . . . . . . . . . . . . . . 5

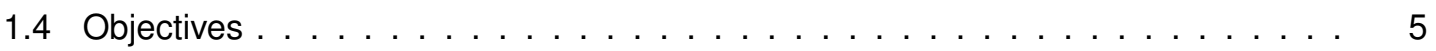

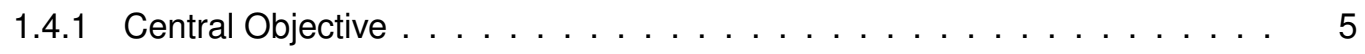

1.4 .2 Explicit Objectives . . . . . . . . . . . . . . . . . 6

2 Methods $\quad 7$

2.1 Data . . . . . . . . . . . . . . . . . . . 7

2.1.1 The Community Earth System Model . . . . . . . . . . . . . . . 7

2.1 .2 CESM-OCN . . . . . . . . . . . . . . . . . . . . . 8

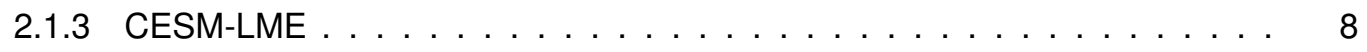

2.1 .4 Ocean Reanalysis Products . . . . . . . . . . . . . . . . . 8

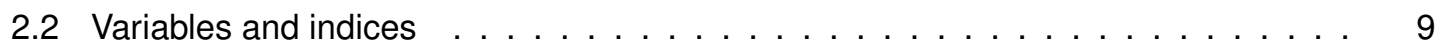

2.2 .1 SBL definition . . . . . . . . . . . . . . . . . . . . 9

2.2.2 SASG dynamical indices $\ldots \ldots \ldots \ldots \ldots . \ldots \ldots$

2.3 Volume transports . . . . . . . . . . . . . . . . . . . . . . . . . . . . . 12

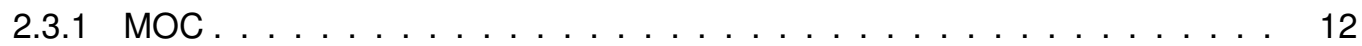

2.4 Low-pass filtering . . . . . . . . . . . . . . . . . . . . . . 13

2.5 Linear trends, Significance Testing and Correlations . . . . . . . . . . . . . 13

3 Results $\quad 14$

3.1 Validation and Characterization . . . . . . . . . . . . . . . . . . . 14

3.2 Long-term change of the SBL . . . . . . . . . . . . . . . . . . . . 19

3.3 Long-term change of SASG dynamics . . . . . . . . . . . . . . . . . . . . . 24

3.4 Long-term change of SAO currents transport . . . . . . . . . . . . . 36

3.4 .1 Total Transports . . . . . . . . . . . . . . . . . . . . . 36

3.4 .2 Barotropic Transports . . . . . . . . . . . . . . . . . . . . . 42 
3.4.3 Linkage between SBL variability and currents' transports . . . . . . . . . 45

3.5 Last Millennium change perspective . . . . . . . . . . . . . . . . . . 47

4 Conclusions and Discussion $\quad 52$

$\begin{array}{ll}\text { References } & 54\end{array}$

$\begin{array}{lc}\text { Appendix I } & 63\end{array}$ 


\section{Agradecimentos}

Já que não havia um número específico de páginas para a seção de agradecimentos, me senti na liberdade de agradecer propriamente todas as pessoas que contribuíram de certa forma para a conclusão deste trabalho, diretamente ou simplesmente se importando e sendo gentil demais comigo para que eu pudesse esquecer. Tomei a liberdade também, de tentar exprimir um pouquinho do propósito que me conduziu ao longo do trabalho e que representa grande parte da minha evolução pessoal durante este período.

Como diz minha orientadora, Ilana Wainer, eu tenho tendência a fazer um mind dump e, portanto, aqui não poderia ser diferente. Então, primeiro, Ilana, eu gostaria de agradecer você. Não só por me proporcionar todo o recurso, suporte e confiança; mas o mais importante de tudo: por ser meu combustível de motivação. Não consigo mensurar a importância do seu incentivo para minha inspiração - é a medida que eu tenho de que estou no caminho certo nos momentos de dúvida. Muito obrigada por tudo e por persistir em me ensinar a pensar como você.

Naturalmente, não tenho como deixar de agradecer minha ex-orientadora, Regina $\mathrm{R}$. Rodrigues - cuja fonte de combustível motivacional eu já explorei bastante - mas sinto dizer que sempre vou precisar de mais (e sei que é inesgotável!). Obrigada por ter me guiado até aqui.

Um agradecimento ao órgão de fomento que financiou o meu mestrado, a Coordenação de Aperfeiçoamento de Pessoal de Nível Superior (CAPES), e ao Instituto Oceanográfico da Universidade de São Paulo (IO-USP) e todos os professores e funcionários de lá que contribuíram para minha formação de certa forma.

Aos membros do lab $\mathrm{OC}^{2}$, vocês são incríveis e eu adoro que façam parte dos meus dias, fazem com que eu sinta que realmente estou no lugar certo. Zé, Mineiro, Bruno, Martim, Marina, Laura e Daniel (que precisa vir nos visitar!), muito obrigado por me aguentarem, por ouvirem todas as minhas ideias malucas e por tirarem as minhas dúvidas. Admiro cada um de vocês.

Aos que enfrentaram a árdua jornada de disciplinas comigo no primeiro ano, me aceitando dentro do grupinho de meninos e ainda sendo sempre muito pacientes e atenciosos ao tentar compartilhar comigo suas teorias de dinâmica. Matheus, lury, Hélio, Dante, muito obrigada!

Sobretudo, meu 'núcleo familiar' - pai, mãe (Roberto, Vânia) e Nathalia: vocês são a base de tudo que eu sou hoje, os que me remetem às minhas verdadeiras raízes. Mesmo cada um em um canto diferente, a coisa mais importante sempre é saber que eu tenho vocês! Pai e mãe obrigada por tudo, por todo o apoio, compreensão e amor incondicional; vocês sempre vão ser os meus maiores exemplos de caráter e bondade. Nathy, minha sis, minha companheira, minha 'cópia' (só que não), obrigada não só por ser quem você é, mas também por ter se prontificado para me ajudar com os gráficos sem medir esforços. É muito legal de repente perceber que sua irmã mais nova pode ajudar no seu trabalho!

Agora, dizem que nós somos uma média das 5 pessoas com quem mais convivemos. Tio Sérgio e Suzete, com certeza hoje eu posso dizer que sou um pouquinho de vocês; e que 
vocês são responsáveis por grande parte do meu crescimento pessoal nesses 2 anos. E toda a gratidão que eu possa expressar aqui através de palavras nunca será suficiente. Obrigada por me acolherem e por me incentivarem tanto! Vocês são extraordinários (mesmo) — ninguém acredita quando falo de vocês. Por outro lado, posso culpá-los por permitir e inclusive estimular e impulsionar o fluxo desenfreado de ideias malucas e reflexões que surgem na minha cabeça. Até giz de cera para escrever no azulejo do box no banho eu ganho; já era esperado que isso não poderia dar muito certo.

Sérgio Júnior, Gustavo, Fernando, Eileen e Mike: também não tenho palavras para agradecer vocês! Que também acompanharam de perto toda a minha jornada do mestrado. Vocês também são demais, sempre de prontidão para me ajudar ou me animar, ou até jogar a Enciclopédia da Oceanografia Física! (Tio e Su inclusos. Eu adorei.) Obrigada por tudo. Cida e Dona Nenê também! Muito queridas, sempre se preocupando e fazendo de tudo por mim.

Vó Cecília, vô Abel, vó Tela, vô Fernando, Marie, Carô (especialista em Convecção nos Oceanos pela Feira de Ciências do colégio Salesiano), tio Wal, Rosana, Lautaro, Rocio, tio Célo, Bete, Marcelli, Gaby — todos também parte de um pouquinho do que sou hoje. E muito especiais para mim.

Minha outra família de coração que me adotou: Letícia, Gustavo, Gui, Malu. Os meIhores in laws possíveis, que não medem esforços para me agradar e também representam exemplos de caráter e bondade para mim. De verdade, todos vocês. Também não tenho como agradecer tudo o que já fizeram e fazem por mim e a maneira como me acolhem.

E por fim, "ao ombro mais chorado da história", meu cúmplice, meu melhor amigo, meu namorado: Gabriel. Lindo, a conquista dessa etapa é sua também, que sempre fez e faz de tudo para incentivar que eu corra atrás dos meus sonhos e busque o melhor de mim. Obrigada por estar ao meu lado e por persistentemente me fazer sentir que sou capaz.

Eu tenho a sorte de ter pessoas muito especiais na minha vida. E quero agradecer todos que contribuíram para o meu crescimento de certa forma, cada qual me somando um pouquinho - me emprestando suas visões e exercitando minha capacidade de empatia, colaboração e criatividade mútua. Que afinal, é o que importa de verdade.

São tantos amigos queridos que sempre demonstram interesse e se importam com o que eu faço... Mais alguns nomes por trás disso são: Lu, Bru Gregs, Bru Queiroz, Ju Gil, Duda, Bibs, Zé, Caio, Ni, Thoff, Devegili, Letícia, Fefi, Diego, Sya... E ainda tem muito mais. Eu sou muito grata por todos vocês terem cruzado o meu caminho!

Eu quero que todos aqui saibam que podem sempre contar comigo e que eu nunca vou medir esforços para ver vocês felizes! Mesmo que já estejam cansados de me ouvir tentando convencê-los a meditar, fazer exercícios e se alimentar mais naturalmente (como diz meu priminho Fê me imitando: "blá-blá-blá, isso faz bem pra saúde"), mas eu juro que é porque eu só quero muito o bem de todos vocês!

Fico feliz em poder dizer que minha evolução pessoal ao longo desses 2 anos de mestrado não se limita somente ao conteúdo estampado nas páginas a seguir, do 'produto final'. 
Acho que quando decidimos entrar num questionamento profundo sobre o que realmente importa, chegamos à conclusão de que o propósito mais puro e nobre é sempre agregar valor, de alguma forma. Então quando entendemos isso, paramos de ter tanto medo.

Este trabalho é novamente só um começo, de eu tentando ser um pouquinho melhor na minha busca por algo significativo. Estou e estarei em constante fase de aperfeiçoamento, e acredito que devemos sempre ser humildes para reconhecer e admitir que nada sabemos perto do universo de conhecimento que nos espera. O importante mesmo é despertar para a curiosidade. Eu sempre sonhei em 'ser cientista' e hoje posso dizer que o meu objetivo é conseguir comunicar ciência para o mundo, de alguma forma, através da minha pesquisa. Acho também que se cada um buscar deixar sua marca em algo específico, por menor que seja, mas que seja verdadeiro e significativo, o mundo vai ser um lugar melhor.

E por isso eu gostaria de passar uma mensagem para todos lendo os meus Agradecimentos até aqui, pois também é uma forma que tenho de agradecê-los ${ }^{1}$. É parte (um pouco adaptada por mim) do capítulo What's Important to You? do livro "Ego Is the Enemy" de Ryan Holiday:

De acordo com Seneca, a palavra grega eutimia é uma sobre a qual deveríamos pensar com mais frequência. É o senso do nosso caminho, como segui-lo sem ser distraído. É sobre ser quem você é, e ser o meIhor possível nisso. Sem sucumbir à todas as coisas que possivelmente te distanciam disso. É sobre ir para onde você determinou que ia. Sobre realizar o melhor que você é capaz, e realizar o que você escolheu. (Ser a melhor versão de você mesmo.)

Por outro lado, eutimia significa perfeita tranquilidade ou serenidade de espírito, sereno contentamento. É hora de sentar e pensar sobre o que é realmente importante para você. E então dar um passo atrás para abandonar todo o resto. Sem isso, o sucesso não será prazeroso, ou sequer tão completo como poderia ser. Ou pior, não irá durar.

Quando você não sabe do quanto você precisa, o padrão facilmente se torna 'mais'.

Então, sem pensar, energia crítica é desviada em função disso. Quando se combina insegurança com ambição, se adquire uma inabilidade em dizer não às coisas.

O ego nos faz querer tudo e, eventualmente, estamos dizendo sim demais. Por razões que nem sequer compreendemos. Mas você precisa saber. Você precisa saber o que você não quer e o que as suas escolhas vão impedir. Porque as estratégias são em geral mutualmente exclusivas; a vida requer trocas, mas o ego não permite.

Por que você faz o que faz?

Essa é a pergunta que você precisa responder.

Encare ela até não poder mais. Só então você vai entender o que importa e o que não. E só então você pode dizer não; você pode optar por abandonar competições estúpidas que não fazem sentido ou nem mesmo existem.

Quanto mais você tem e faz, mais difícil será manter fidelidade ao seu propósito, mas o mais criticamente você precisará. Todos caem no mito de que, se ao menos tivessem 'aquilo' — geralmente o que outra pessoa tem — seriam felizes. Talvez seja preciso "se queimar" algumas vezes para perceber o vazio dessa ilusão.

Todos nós ocasionalmente nos vemos em meio a um projeto ou obrigação e não conseguimos entender porque estamos lá. Será preciso coragem e fé para se auto-impedir.

Descubra por que você está atrás do que está atrás. Ignore aqueles que confundem seu caminho. Deixe que eles cobicem o que você tem, e não o contrário. Porque isso é independência.

\footnotetext{
${ }^{1}$ Também como uma forma de agradecimento à toda a minha família e amigos, que frequentemente me perguntam sobre o que eu estou estudando, elaborei um simples Resumo Informal para esses leitores de fora da área de Oceanografia Física que estão folhando o meu trabalho. Está apresentado como Apêndice I, ao final do documento.
} 


\section{Abstract}

Through analysis of large-scale ocean gyre dynamics from simulation results of the ocean component of the Community Earth System Model version 1 - the Parallel Ocean Program version 2 (CESM1-POP2) - this study builds upon existing research suggesting recent changes in the circulation of global subtropical gyres with respect to the South Atlantic Ocean. Results all point to an increase in the total counterclockwise circulation and a southward displacement of the subtropical gyre system. The northern boundary of the South Atlantic Subtropical Gyre (SASG) is represented by the bifurcation of the southern branch of the South Equatorial Current (SSEC) into the North Brazil Undercurrent/Current (NBUC/NBC) to the north and the Brazil Current (BC) to the south. The SSEC Bifurcation Latitude (SBL) dictates the partition between waters flowing poleward and those flowing equatorward. Although a northward migration of the SBL would be expected with the gyre spin up and associated poleward transport increase, the SBL migrates southwards at a rate of $0.051^{\circ} / \mathrm{yr}$, in conjunction to a substantial increase in the equatorward advection of waters within the SSEC-SBL-NBUC system, which is included in the upper-branch of the Atlantic Meridional Overturning Circulation.

Keywords: South Atlantic Ocean. Subtropical gyre circulation. sSEC Bifurcation Latitude. Southward migration. 


\section{Resumo}

Através de análises da dinâmica de grande-escala do giro oceânico, proveniente dos resultados de simulação da componente oceânica do Community Earth System Model versão 1 - o Parallel Ocean Program versão 2 (CESM1-POP2) - este estudo se baseia em estudos prévios sugerindo mudanças recentes na circulação dos giros subtropicais globais, com respeito ao oceano Atlântico Sul. Os resultados apontam para uma intensificação da circulação anti-horária e um deslocamento para sul de todo o sistema do giro subtropical. A borda norte do Giro Subtropical do Atlântico Sul (GSAS) é representada pela bifurcação do ramo sul da Corrente Sul Equatorial (CSEs) em Subcorrente/Corrente Norte do Brasil (SCNB/CNB) para norte e Corrente do Brasil (CB) para sul. A Latitude da Bifurcação da CSEs (LBC) determina a partição entre as águas fluindo em direção ao pólo e aquelas fluindo em direção ao equador. Embora seja esperada uma migração para norte da LBC com a aceleração da circulação do giro e consequente aumento do transporte em direção ao pólo, a LBC migra para sul a uma taxa de $0.051 \%$ ano. Esta migração ocorre em conjunto à um aumento substancial na advecção de águas em direção ao equador com o sistema CSEs-LBC-SCNB, o qual está incluso no ramo superior da Circulação de Revolvimento Meridional do Atlântico.

Palavras-chave: Oceano Atlântico Sul. Circulação de giro subtropical. Latitude da Bifurcação da CSEs. Migração para sul. 


\section{List of Figures}

1 Schematic representation of upper South Atlantic circulation. | Shown are the major wind-driven currents (black arrows) and mean Wind Stress Curl (N.m ${ }^{-3}$, background colors). Abbreviations are used for the South Atlantic Subtropical Gyre (SASG), Brazil Current (BC), South Atlantic Current (SAC), Benguela Current $(\mathrm{BeC})$, southern branch of the South Equatorial Current (sSEC), sSEC Bifurcation Latitude (SBL), North Brazil Undercurrent (NBUC), Equatorial Undercurrent (EUC), Antarctic Circumpolar Current (ACC) and Malvinas Current (MC). Adapted from Pontes et al. (2016) [Figure 1 from their Supplementary Information]. . . . . . | Large-scale SAO dynamical fields. | Climatological (a) WSC, (b) SSH, (c) BSF and (d) SST. Contours are every (a) $2.5 \times 10^{-8} \mathrm{~N} \cdot \mathrm{m}^{-3}$, (b) $5 \mathrm{~cm}$, (c) $5 \mathrm{~Sv}$ and (d) $1^{\circ} \mathrm{C}$. Zero contours which delimitate positive (negative) WSC/SSH (BSF) fields are indicated by black solid lines. Also highlighted by black dashed lines are the (a) $5 \times 10^{-8} \mathrm{~N} \cdot \mathrm{m}^{-3}$, (b) $15 \mathrm{~cm}$, (c) $-10 \mathrm{~Sv}$ and (d) $10^{\circ} \mathrm{C}, 15^{\circ} \mathrm{C}, 20^{\circ} \mathrm{C}, 25^{\circ} \mathrm{C}$ contours; used as parameters to perform index calculations.

SSEC bifurcation vertical profile from the reanalysis products and model results. Mean meridional velocity $\left(\mathrm{m} . \mathrm{s}^{-1}\right.$ ) averaged over the western boundary layer ( $<4^{\circ}$ from the coast) from ocean reanalysis products (a-e) and from model results (f-g). Positive (negative) values indicate northward (southward) flow associated with the NBUC (BC), and the contour of zero velocity represents the bifurcation of the SSEC. SSEC bifurcation vertical profile, extracted from Rodrigues et al. (2007). Annual mean (a) geostrophic meridional velocity from observations and (b) total meridional velocity from model results. The velocities $\left(\mathrm{m} . \mathrm{s}^{-1}\right)$ are averaged within a $2^{\circ}$ longitude band off the South American coast.

Depth-integrated flow over the upper $50 \mathrm{~m}$ (blue vectors). | Derived from ocean reanalysis products: (a) ORAS4, (b) GFDL, (c) SODA216, (d) GODAS, (e) CFSR; and from model results: (f) CESM-OCN and (g) CESM-LME. The dark dots indicate the mean position of the SBL, and the red lines indicate the zero contour of the wind stress curl integrated from east to west. . . . . . . . . . . . . 
6 | Long-term change of the SBL. | (a) Low-pass-filtered (15-month multi-running mean) SBL time series. The blue (green) dots indicate the linear trend for the CESM-OCN (ORAS4) during 1948-2015 (1960-2010). Both linear trends are subtracted by $5^{\circ}$ for clarity. Solid (dashed) vertical lines indicate the period of northerly (southerly) SSBL used to average the SSEC bifurcation vertical profile in $6 \mathrm{~b}$ and annual cycle in $6 \mathrm{~d}$. (b) Vertical profile of the SSEC bifurcation (i.e., contour of zero meridional velocity averaged within a $4^{\circ}$ longitude band off the South American coast) averaged during years of northerly SSBL (1965-1980 - solid line) and southerly SSBL (2000-2015 - dashed line), according to the time series in 6a. Blue (light blue) asterisks indicate the level used to derive the SSBL time series in $6 \mathrm{a}$ (the SBL time series at $100 \mathrm{~m}$ in Fig. 7). (c) SSBL monthly anomalies (i.e., annual cycle was removed). Yellow solid line indicates the linear trend for 1970-2015. (d) Climatological SSBL for years of northerly (solid line) and southerly (dashed line) bifurcation position, also according to the time series in $6 \mathrm{a}$. For clarity, the monthly values are plotted for a 2 -year time period. . . . . . . . . . . . . . . . . 20

7 | Time series of the SBL anomalies at $\mathbf{1 0 0 ~} \mathrm{m}$. | Monthly means (light gray) overlaid by low-passed, 15-month multi-running means (light blue). The light blue dots indicate the linear trend for the period of $1980-2015$, which is subtracted by $5^{\circ}$ for clarity. The position used to derive the time series (100 $\mathrm{m}$ depth) is indicated by the light blue asterisk in Figure $6 \mathrm{~b} . \ldots \ldots \ldots \ldots$

SBL Seasonal Variability. | (a) Full-depth (0-600 m) SSEC Bifurcation annual march, denoting the vertical profile for months of northernmost position (NP) and southernmost position (SP), as well as months in between. (b) Climatological sSBL derived from CESM-OCN (solid black, 1948-2015 base period), ORAS4 (dashed gray, 1960-2010 base period) and CFSR (dashed orange, 1960-2010 base period), where red (blue) asterisk indicates the NP (SP) for CESM-OCN. (c) Time series of the monthly SSBL (blue) and seasonal amplitude (brown). (d) SBL time series only for months of NP (red) and SP (blue) in each year. (e) Respective months of NP (red) and SP (blue) in each year. Straight lines represent the climatological months of NP and SP (December and July, respectively). (f) Difference in the SSEC bifurcation vertical profile between 1965-1980 and 2000-2015 (as in Fig. 6b), except that averaged only for the months of SSBL NP. (g) Same as 8f, but for the 
Background colors show the mean WSC field (contour interval: $0.5 \mathrm{~N} . \mathrm{m}^{-3}$ ), where positive values within the gyre are bounded by thin black dotted lines (WSC0 contour). Thick gray dashed lines demarcate the contour of $\mathrm{SSH} 0$, while gray zonal labels indicate the widths used to derive the time series of the position of maximum zonally averaged $\mathrm{SSH}\left(35^{\circ}-25^{\circ} \mathrm{W}\right.$, center) and of the $\mathrm{SSH} 0$ at a western $\left(40^{\circ}-20^{\circ} \mathrm{W}\right)$ and an eastern portion of the basin $\left(10^{\circ} \mathrm{W}-10^{\circ} \mathrm{E}\right)$. Thick white dashed lines demarcate the contour of BSF0. (Bottom) Same as top panel but with mean SVT field as background colors (contour interval: $5 \mathrm{~Sv}$ ), where positive values within the gyre are bounded by the thick solid black line. The black dot centered at $36^{\circ} \mathrm{W}$ shows the location used to derive the SVTO time series at the northern boundary. White labels denote the widths and location used to derive the time series of the position of maximum zonally averaged $|\mathrm{BSF}|\left(45^{\circ}-25^{\circ} \mathrm{W}\right.$, center) and of the BSF0 at a western $\left(50^{\circ}-20^{\circ} \mathrm{W}\right)$ and an eastern portion of the basin $\left(10^{\circ} \mathrm{E}\right) . . \ldots \ldots$. . . . .

10 | Transition of South Atlantic zonally averaged fields. | (a) Wind Stress Curl (black curve) and Zonal Wind Stress (TAUX, gray curve); (b) Sverdrup Transport; (c) Sea Surface Height, from the western boundary up to $10^{\circ} \mathrm{W}$ (recall Fig. 2b); (d) Barotropic Stream Function; (e) Sea Surface Temperature; and (f) Meridional Velocity, from the South American coast (i.e., the western boundary) up to $4^{\circ}$ Iongitude eastwards. The velocities are also vertically averaged within the top $200 \mathrm{~m}$ layer. Solid (dashed) lines represent the period ranging 1948-1979 (1980-2015). The WSC, TAUX, SVT, BSF and SST are zonally averaged along the entire basin.

11 | Low frequency SASG variability. | Low-passed anomalies of mean (a) WSC, (c) SSH and (e) BSF horizontally averaged inside their zero contour within the SASG (gray); of the corresponding area enclosed by the respective zero contour (light blue) and resulting time series of mean WSC/SSH/BSF per area (i.e., the gray divided by the blue line - in thick black lines). (b) (d) (f) Same as (a)/(c)/(e) but averaged inside the (b) $5 \times 10^{-8} \mathrm{~N} \cdot \mathrm{m}^{-3}$ WSC line, (d) $15 \mathrm{~cm} \mathrm{SSH}$ line, and (f) -10 Sv BSF line (recall Figure 2 from Section 2.2.2 for reference, where these specific contours are shown) . . . . . . . . . . . . . . . . . . . . . .

12 Highlights of the 21st century intensification of SASG circulation. | Climatological mean (a) WSC, (b) SSH and (c) BSF fields with their respective zero contours indicated for reference. (d) Low-passed (35-month multi-running mean), normalized (by standard deviation) anomalies of mean WSC (dark blue), SSH (green) and BSF (lilac) per area, within the zero contours (same time series as in Figure 11a, c, e; save for the differentiated statistical treatment). 
13 | Intensity and latitude of maximum zonally averaged fields. | Low-passed time series of (a) maximum WSC and (b) respective latitude of maximum WSC, averaged over $70^{\circ} \mathrm{W}-20^{\circ} \mathrm{E}$; (c) maximum SSH and (d) respective latitude of maximum $\mathrm{SSH}$, averaged over $35^{\circ}-25^{\circ} \mathrm{W}$; (e) maximum $|\mathrm{BSF}|$ and (f) respective latitude of maximum $|\mathrm{BSF}|$, averaged over $45^{\circ}-25^{\circ} \mathrm{W}$. The zonal bands used for averaging the SSH and BSF are displayed as gray and white labels in Fig. 9. Total linear trends (1948-2015, red solid lines) are subtracted by: (a) $2 \times 10^{-8} \mathrm{~N} \cdot \mathrm{m}^{-3}$, (b) $2^{\circ}$, (c) 3.5 $\mathrm{cm}$, (d) $4.5^{\circ}$, (e) $6 \mathrm{~Sv}$ and (f) $1^{\circ}$, for clarity. Dashed red lines denote linear trends for separate periods: (a, e) 1948-1979 / 1980-2015; (d) 1975-2015. All the linear trends displayed (both total and separated periods) are statistically significant at

| Featuring the SASG poleward displacement and core intensification. | Climatological contours for the periods: 1948-1979 (solid lines) and 1980-2015 (dashed lines). Shown are the: (a) SVT, (b) SSH, (c) BSF and (d) SST fields. . . . . . . . .

15 Monitoring the position of SASG dynamical boundaries. | Low-pass-filtered time series of the latitude of zero contour indices derived from regions of high gradient: (a) Latitude of the SVTO at the northern edge (SVTOn) in the $1^{\text {st }}$ grid point off the South American coast, i.e., the position of zero zonally integrated WSC line; (b) Latitude of the SSHO at the southern edge (SSHOs) in two portions along the basin: a western band ranging $40^{\circ}-20^{\circ} \mathrm{W}$ (solid line) and an eastern one, $10^{\circ} \mathrm{W}$ $10^{\circ} \mathrm{E}$ (dashed line); (c) Latitude of the BSF0 at the southern edge (BSF0s) in two portions along the basin as well: a western band ranging $50^{\circ}-20^{\circ} \mathrm{W}$ (solid line) and an eastern section at $10^{\circ} \mathrm{E}$ (dashed line). (d) Latitude of SST contours in two portions along the basin - the $25^{\circ} \mathrm{C}$ isotherm at $30^{\circ} \mathrm{W}$ (red solid line) and the $20^{\circ} \mathrm{C}$, $15^{\circ} \mathrm{C}$ and $10^{\circ} \mathrm{C}$ (in light red, light blue and blue solid lines, respectively) isotherms at $30^{\circ} \mathrm{W}$ and $0^{\circ}$ longitude (in solid and dashed lines, respectively).

16 | Climatological flow field (1948-2015). | Depth integrated horizontal velocities in which positive velocities (northward, eastward) are in red, while negative velocities (southward, westward) are in blue. The zero-velocity line is marked in black-bold and the $|0.02| \mathrm{m} . \mathrm{s}^{-1}$ contour, used for reference, is marked by the black-dashed lines. The vertical black line along $30^{\circ} \mathrm{W}$ at the right panel $(\mathrm{b})$ indicates whereupon the spatial domain transcends that of the left panel (a). (a) 0-200 m mean meridional velocities. Positive (negative) values denote northward (southward) flow. Yellow dot centered at $19^{\circ} \mathrm{S}$ represents the 0-200 m mean SBL $\left(<4^{\circ}\right.$ longitude off the coast) and solid yellow lines at $6.5^{\circ} \mathrm{S}$ from $35^{\circ}-32^{\circ} \mathrm{W}$ and at $28.5^{\circ} \mathrm{S}$ from $48^{\circ}-44^{\circ} \mathrm{W}$ represent transects for the calculation of NBUC and BC transports, respectively. (b) 0-200 m mean zonal velocities. Negative (positive) values denote westward (eastward) flow. Solid yellow line at $30^{\circ} \mathrm{W}$ from $6^{\circ}-22^{\circ} \mathrm{S}$ represent the transect for the calculation of the SSEC transport. 

mean vertical profile across $30^{\circ} \mathrm{W}$ represented by the $1948-2015$ average zonal velocity field along $0^{\circ}-30^{\circ} \mathrm{S}$ latitude and up to $980 \mathrm{~m}$ depth. The westward flow is indicated by the negative values in blue. The eastward core (positive values, in red) centered in the equator above $200 \mathrm{~m}$ represents the SECC. The zero-velocity line is marked in bold and the $|0.02| \mathrm{m} . \mathrm{s}^{-1}$ contour used for reference as in Fig. 16 is indicated by the dashed lines. (b) Low-passed time series of the respective westward transport fluctuations at $30^{\circ} \mathrm{W}$ (along $6^{\circ}-22^{\circ} \mathrm{S}$ and above $200 \mathrm{~m}$ ) about its mean volume of $12.95 \mathrm{~Sv} . \ldots \ldots \ldots \ldots$

BC vertical profile characterization and transport time series. | (a) BC mean vertical profile across $28.5^{\circ} \mathrm{S}$ represented by the 1948-2015 average meridional velocity field along $49^{\circ}-44^{\circ} \mathrm{W}$ longitude and up to $980 \mathrm{~m}$ depth. The southward flow is indicated by the negative values in blue. The zero-velocity line is marked in bold and the $|0.02| \mathrm{m} . \mathrm{s}^{-1}$ contour used for reference as in Fig. 16 is indicated by the dashed lines. (b) Low-passed time series of the respective southward transport fluctuations at $28.5^{\circ} \mathrm{S}$ (along $48^{\circ}-44^{\circ} \mathrm{W}$ and above $200 \mathrm{~m}$ ) about its mean volume

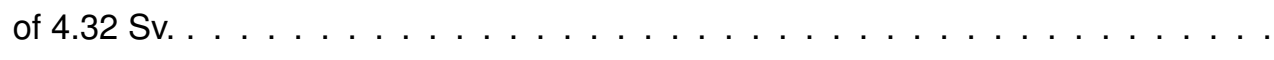

NBUC vertical profile characterization and transport time series. | (a) NBUC mean vertical profile across $6.5^{\circ} \mathrm{S}$ represented by the 1948-2015 average meridional velocity field along $36^{\circ}-31^{\circ} \mathrm{W}$ longitude and up to $980 \mathrm{~m}$ depth. The northward flow is indicated by the positive values in red. The zero-velocity line is marked in bold and the $|0.02| \mathrm{m}^{-1} \mathrm{~s}^{-1}$ contour used for reference as in Fig. 16 is indicated by the dashed lines. (b) Low-passed time series of the respective northward transport fluctuations at $6.5^{\circ} \mathrm{S}$ (along $35^{\circ}-32^{\circ} \mathrm{W}$ and above $200 \mathrm{~m}$ ) about its mean volume of $12.47 \mathrm{~Sv}$.

| Highlights of the synchrony between SSEC and NBUC transport anomalies.

Comparison of the (standardized, low-passed) time series of the SSEC (blue, same as in Fig. 17) with the NBUC anomalies (red, same as in Fig. 19). The value on top of the plot indicates the correlation coefficient between the series.

21 Attribution of NBUC transport increase to MOC intensification. | Comparison of the (low-pass-filtered) time series of the NBUC anomalies (red) at $6.5^{\circ} \mathrm{S}$ with the corresponding MOC anomalies at this latitude (light gray) and the MOC anomalies at $26.5^{\circ} \mathrm{N}$ (black). Both MOC streamfunctions are vertically integrated above 1000-m depth; their time series are scaled by a factor of $10^{-6}$. The dashed lines indicate the respective linear trends for the period 1970-2015, which are all statistically significant at the $95 \%$ confidence level. Values on top of the plot indicate the correlation coefficient between the normalized, detrended time series: the NBUC transport and the MOC at $6.5^{\circ} \mathrm{S}$ (cc1); the NBUC transport and the MOC at $26.5^{\circ} \mathrm{N}$ (cc2); and between the MOC at $6.5^{\circ} \mathrm{S}$ and the MOC at $26.5^{\circ} \mathrm{N}$ (cc3). . . . . . . . . 
Climatological BSF field (1948-2015). | Solid yellow (gray) lines represent transects used to derive the barotropic transport time series of SASG boundary currents (of SAO currents outside the subtropical gyre). Contours are every $5 \mathrm{~Sv}$. . .

23 | SAO barotropic transport variation. | Low-passed anomalies of the barotropic transport of SAO currents at the locations indicated in Figure $22 \ldots \ldots$. . . . . . . 43

24 | SSBL relationship with SSEC, NBUC and BC transports. | Low-passed (35month), standardized time series of the SSBL (in light blue, for all panels) and the total (solid lines) and barotropic (dashed lines) transports of (a) the SSEC across $30^{\circ} \mathrm{W}$, (b) the NBUC across $6.5^{\circ} \mathrm{S}$ and (c) the BC across $28.5^{\circ} \mathrm{S}$. Values on top of the plot indicate the correlation coefficient between the series: cc1 (cc2) quantifies the relation between the SBL and the total (barotropic) transports.

25 | SBL time series for the Last Millennium. | Low-passed (30-yr) time series of the SBL at the surface (the SSBL - a, b) and at $100 \mathrm{~m}(\mathbf{c}, \mathbf{d})$. Subplots $(\mathrm{a}, \mathrm{c})$ show the time series for the 10 ensemble members of the CESM-LME (in gray) plus the control-run (CTRL, yellow) - which is not subject to external forcings. Solid black-bold lines denote the average of the 10 ensembles members (the Ensembles' mean). Vertical dashed green (light blue) line indicates the year of 1850 (1980). Subplots (b, d) show the Ensembles' mean anomaly time series with the spread (red) and spread times -1 (blue).

26 Late NBUC transport increase and MOC intensification relative to the Last Millennium. | Low-passed (30-yr) anomalies of the NBUC transport (red) at $6.5^{\circ} \mathrm{S}$ and the corresponding MOC streamfunction at this latitude (light gray). As in Figure 21 , the MOC streamfunction is vertically integrated above 1000-m depth and its time series is scaled by a factor of $10^{-6}$. The correlation coefficient between the standardized time series is indicated by cc1. Vertical dashed green (light blue) line indicates the year of 1850 (1980).

27 | Recent transition in South Atlantic zonally averaged fields. | (a) Wind Stress Curl, along $30^{\circ}-10^{\circ} \mathrm{W}$; (b) Sea Surface Temperature, along $40^{\circ}-20^{\circ} \mathrm{W}$; (c) Sea Surface Height, along $35^{\circ}-25^{\circ} \mathrm{W}$ and (d) Barotropic Stream Function, along $50^{\circ}-20^{\circ} \mathrm{W}$. The gray line represents the Last Millennium climatology (850-1850), blue line represents roughly the 20th century climatology (1850-2005) and red line the climatology from the last 25 years of the CESM-LME record (1980-2005).

28 | Southward shift of the SASG system relative to the Last Millennium. | Lowpassed latitudes of: (a) maximum WSC, (c) SSH and (e) BSF; and of SASG dynamical boundaries - (b) SVTO at northern limb, (d) SSHO and (f) BSFO at southern limbs. Vertical dashed green (light blue) line indicates the year of 1850 (1980). . . 
29 | Representação esquemática do Atlântico Sul e da região equatorial. | Contornos em preto representam as correntes superficiais e cores de fundo, a Temperatura da Superfície do Mar (Sea Surface Temperature). O giro subtropical do AS é formado por parte do sistema de correntes da Benguela na borda leste (Benguela Current System), o ramo sul da Corrente Sul Equatorial (CSEs) na borda nordeste/norte (southern South Equatorial Current), a Corrente do Brasil (CB) na borda oeste fluindo para sul (Brazil Current) e a Corrente do Atlântico Sul fluindo para leste no limite inferior (South Atlantic Current). Extraído de Cabos et al. (2016). . . . . . . . . . . . . . . . . . . . . . . 


\section{List of Tables}

1 Time period, horizontal resolution and number of vertical layers above $1000 \mathrm{~m}$ of

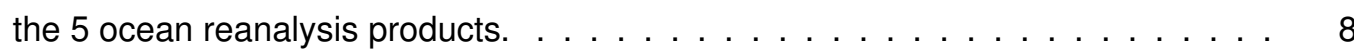

2 SBL values obtained by R2007 from hydrographic observations; derived from ocean reanalysis products and obtained from the CESM-models results. . . . . . . . . . 17

3 Magnitude of the seasonal amplitude of worldwide bifurcations, in comparison to the $\mathrm{SBL}$ in the SAO. . . . . . . . . . . . . . . . . . . . . . . . 23

4 Comparison of the southward shift of the SAO SBL in this study with Pacific NBL and SBL, from Chen and Wu (2012) and Zhai et al. (2014), respectively. . . . . . . 24

5 Total period mean value and increase corresponding to the 1980-2015 period of the time series of mean WSC, SSH and BSF within contours (displayed as gray lines in Figure 11). The mean values refer to the corresponding raw time series (since the anomalies in Fig. 11 are with respect to their annual cycles). . . . . . . . . . 29

6 Linear trends from the time series in Fig. 13. The separate period ranging 19481979 (1975/1980-2015) is marked in brown (red), for reference. . . . . . . . . . . . 32

7 Total shift depicted by different periods in the time series from Figure 15. Shown are only the shifts corresponding to statistically significant linear trends, at the $95 \%$ confidence level. The 1970-2015 separate period is marked in red, for reference. . 35

8 Total increase in barotropic transports corresponding to linear trends from the time series in Fig. 23. The linear trends are all statistically significant at the $95 \%$ confidence level. 


\section{List of Abbreviations}

ACC Antarctic Circumpolar Current

AMOC Atlantic Meridional Overturning Circulation

BC Brazil Current

BeC Benguela Current

BMC Brazil-Malvinas Confluence

BSF Barotropic Stream Function

BSF0 Zero BSF Line

BSF0s BSF0 at southern edge

CESM Community Earth System Model

CFSR Climate Forecast System Reanalysis

ECMWF European Center for Medium-Range Weather Forecasts

ENSO El Niño - Southern Oscillation

GFDL Geophysical Fluid Dynamics Laboratory

GODAS Global Ocean Data Assimilation Systemgulf

MC Malvinas Current

MOC Meridional Overturning Circulation

NAO North Atlantic Oscillation

NBC North Brazil Current

NBUC North Brazil Undercurrent

NCEP National Centers for Environmental Prediction

NEC North Equatorial Current

NP Northernmost Position

NPO North Pacific Ocean

ORAS4 Ocean Reanalysis System 4

PDO Pacific Decadal Oscillation

POP Parallel Ocean Program

SAO South Atlantic Ocean

SAC South Atlantic Current 
SASG South Atlantic Subtropical Gyre

SBL SSEC Bifurcation Latitude

sSBL SSEC Bifurcation Latitude at the surface

SEC South Equatorial Current

cSEC central branch of the South Equatorial Current

eSEC equatorial branch of the South Equatorial Current

nSEC northern branch of the South Equatorial Current

SSEC southern branch of the South Equatorial Current

SECC South Equatorial Countercurrent

SEUC South Equatorial Undercurrent

SH Southern Hemisphere

SIO South Indian Ocean

SODA216 Simple Ocean Data Assimilation version 2.1.6

SP Southernmost Position

SPO South Pacific Ocean

SSH Sea Surface Height

SSHO Zero SSH Line

SSHOs SSHO at southern edge

SST Sea Surface Temperature

SVT Sverdrup Transport

SVTO Zero SVT Line

SVTOn SVTO at northern edge

WBC Western Boundary Current

WSC Wind Stress Curl

wsco Zero WSC Line 


\section{Introduction}

\subsection{Subtropical gyres and climate variability}

Anticyclonic subtropical gyres dominate the circulation at midlatitudes in each of the five ocean basins, providing a major pathway for water in the subtropics to be transported to the equator and high latitudes, which is believed to play a key role in modulating the world's climate system. Subtropical gyres circulation is, therefore, closely related to global climate variability.

The South Atlantic Ocean (SAO), for instance, is characterized by substantial variability from intraseasonal to interdecadal and longer time scales, which have significant impacts on neighbouring South America and southern Africa, as well as further afield (Wainer and Venegas, 2002). Although the mechanisms associated with this variability remain poorly understood, modulations of the South Atlantic anticyclone and the subtropical gyre seem to play a central role (International CLIVAR Project Office, 2007; Lübbecke et al., 2014; Cabos et al., 2016).

Furthermore, interactions between physical and biological processes within the subtropical gyres are also critical in determining the magnitude and variability of the carbon exported from the surface to the deep ocean. Ecosystem indicators which are present in subtropical gyres respond to climate variability (Karl et al., 2001; Andreas Oschlies, 2001), since physical-biological coupling between climate cycles (such as the EI Nino-Southern Oscillation (ENSO), the Pacific Decadal Oscillation (PDO), the North Atlantic Oscillation (NAO) and so on) and ecosystem dynamics is a consequence of altered nutrient flux pathways that result from changes in the stratification and circulation of the subtropical gyres (McClain et al., 2002).

Over the past century, there has been direct and indirect evidence supporting changes having occurred in the subtropical gyres (Hu et al., 2015). These changes include an intensification (Li et al., 2012, 2013) and poleward expansion (Saenko et al., 2005; Zhang et al., 2013) of these oceanic gyres in both hemispheres, featuring a southward shift of the position of zero wind stress curl in the mid-latitudes of the Southern Hemisphere $(\mathrm{SH})$ and a spin-up of the Southern Ocean super-gyre (Alory et al., 2007; Beal et al., 2011; Biastoch et al., 2009; Cai et al., 2005; Cai, 2006; Roemmich et al., 2007; Roemmich, 2007; Saenko et al., 2005) associated with changes in ozone and $\mathrm{CO}_{2}$ forcing (Cai and Cowan, 2007; Arblaster et al., 2011; Polvani et al., 2011) which project onto the Southern Annular Mode (SAM). The SAM is the dominant mode of the SH extratropical circulation (e.g., Thompson and Solomon, 2002; Marshall, 2003).

Moreover, in conjunction with a systematic change in winds over both hemispheres, it is found an accelerated surface ocean warming along the path of global subtropical western boundary currents (WBCs) in association with a synchronous poleward shift of their mid-latitude extensions and/or an intensification in their strength (Wu et al., 2012).

The aforementioned studies are rather focused on other individual ocean basins or take a more global perspective. Relative to the South Atlantic Subtropical Gyre (hereafter, SASG) circulation, however, little is known about its basin-scale climate variability and long-term changes. 
Except for the numerical coupled model analysis from Wainer et al. (2004), who suggested an increased barotropic transport associated with the intensification of the SASG and the ACC under a global warming scenario; and for the recent study by Pontes et al. (2016), based on 19 models from the Coupled Model Intercomparison Project phase 5, which show projections of changes in large-scale features of the SAO circulation under increasing greenhouse gases; previous studies have mainly addressed features located further south, especially the Brazil-Malvinas Confluence (BMC), which is documented to be drifting southwards (Goni et al., 2011; Lumpkin and Garzoli, 2011; Combes and Matano, 2014; Pontes et al., 2016).

It is particularly important, though, to better investigate the SAO circulation variability as a whole, considering it takes place in the only basin which is in direct contact with all the other major oceans and therefore in a rather unique position to influence their inter-basin exchanges (International CLIVAR Project Office, 2007).

The pattern of gyre-scale flow in the SAO is strongly influenced by these interocean connections, which play an important role in the thermohaline circulation (Reid, 1994). These interocean exchanges permit the thermohaline regimes of neighboring oceans to interact on a variety of timescales. In this process, external forcings may induce variability in the South Atlantic boundary currents, which may, in turn, impact the whole of the SASG. Studies of the gyre-scale circulation and of low-frequency variability in the boundary current regimes may, therefore, provide insight to variations of the thermohaline circulation (Witter and Gordon, 1999).

\subsection{The South Atlantic Subtropical Gyre and the sSEC Bifur- cation}

Transfer of heat and salt of the northward return limb of the Atlantic Meridional Overturning Circulation $(A M O C)$ takes place in the upper Atlantic Ocean where the Agulhas Leakage plays a significant role according to recent studies (e.g., Donners and Drijfhout, 2004; Gordon et al., 1992; Gordon, 1985, 1986; Holfort and Siedler, 2001; Rodrigues et al., 2010; Weijer et al., 2001; Weijer and Ruijter, 2002). Therefore, the SAO circulation is remarkable in at least two major ways: this intermittent supply of heat and salt received from the South Indian Ocean (e.g., Beal et al., 2011; Richardson, 2007; de Ruijter et al., 1999) and the anomalous net northward heat transport occurring in the low and midlatitudes (e.g., Vellinga and Wu, 2004). With the SAO being the critical crossroad for the meridional circulation, the underlying cause-response relations between its wind-driven features and the overturning components are undeniable.

The SASG encompasses a system of wind driven surface currents (e.g., Peterson and Stramma, 1991; Stramma and England, 1999) (Figure 1). It is comprised by the southward western boundary Brazil Current $(B C)$, flowing along the South American coast until it meets the northeastward extension of the ACC into the Atlantic, the MC, characterizing the BMC (Garzoli, 1993; Gordon, 1985, 1989). From there on, an eastward meandering flow is formed, originating the South Atlantic Current (SAC) (Stramma and Peterson, 1990), which is the southern limb of the 
subtropical gyre. The SAC partially feeds the eastern boundary Benguela Current $(\mathrm{BeC})$, recirculating within the subtropical gyre. The $\mathrm{BeC}$ then heads northwestward turning into the southern branch of the South Equatorial Current (SSEC), which is the one that forms the northern edge of the subtropical gyre (Stramma, 1991; Goni et al., 2011). The broad, westward flowing sSEC carries these subtropical waters towards the Brazilian shelf region, where it bifurcates around $15^{\circ} \mathrm{S}$, closing the subtropical gyre by flowing into the southward BC (Reid, 1994; Rodrigues et al., 2007; Stramma et al., 1990).

The bifurcation of the SSEC also gives rise to an equatorward low-latitude WBC - the North Brazil Undercurrent (NBUC), besides the subtropical BC. As the SSEC splits into two branches, the SSEC Bifurcation Latitude (hereafter, SBL) becomes an important indicator of the partition of the SSEC mass, heat and salt between its northward and southward components. The SBL is indicative of how much subtropical water bends equatorward to flow into the tropical/equatorial region via the NBUC and how much turns poleward recirculating in the subtropical gyre via the BC; given that as the SSEC bifurcation moves southward (northward) the NBUC transport increases (decreases) and the BC transport decreases (increases) (Rodrigues et al., 2007 - hereinafter referred to as R2007).

Many studies have been developed for the long-term variation of equatorial currents' bifurcation in other ocean basins, which suggest that there has been a synchronous southward shift of the Pacific North and South Equatorial Current (NEC and SEC) bifurcations over the past 60 years (Chen and Wu, 2012 and Zhai et al., 2014, respectively; summarized in Fig. 4 from Hu et al., 2015). As for the SAO, however, previous studies have only described the SSEC bifurcation mean position (Boebel et al., 1999; Harper, 2000; Malanotte-Rizzoli et al., 2000; Stramma and England, 1999; Wienders et al., 2000) or even investigated its seasonal variability and mechanisms involved (R2007).

The SSEC bifurcation in the SAO can have important consequences for climate variability. Besides setting the northern limit of the SASG, it involves other two important scenarios regarding the large-scale SAO circulation: the SSEC-SBL-NBUC system is the main conduit for upper-ocean return flow of the Meridional Overturning Circulation (MOC) (Talley, 2003; Ganachaud, 2003; Lumpkin and Speer, 2003) and for the subtropical-tropical mass exchange (McCreary and Lu, 1994; Malanotte-Rizzoli et al., 2000; Zhang et al., 2003).

It is worth mentioning that, in the Atlantic Ocean, nearly $2 / 3$ of the water encountered in the equatorial thermocline comes from the South Atlantic and not from the North Atlantic (Metcalf and Stalcup, 1967; Wilson et al., 1994; Schott et al., 1995; Harper, 2000; Zhang et al., 2003). The presence of the northward upper limb of the MOC in the SAO increases the flow of the equatorward western boundary current (the NBUC), diminishing the poleward BC transport.

The path along the warm route of the AMOC depicts a northward advection through the BeC-sSEC-NBUC-NBC crossing the equator and joining the Gulf Stream in the northern hemisphere, followed by complex pathways from the subtropics to the subpolar gyre and Nordic Seas. The participation of the SSEC bifurcation in this scenario illustrates an external forcing mechanism 


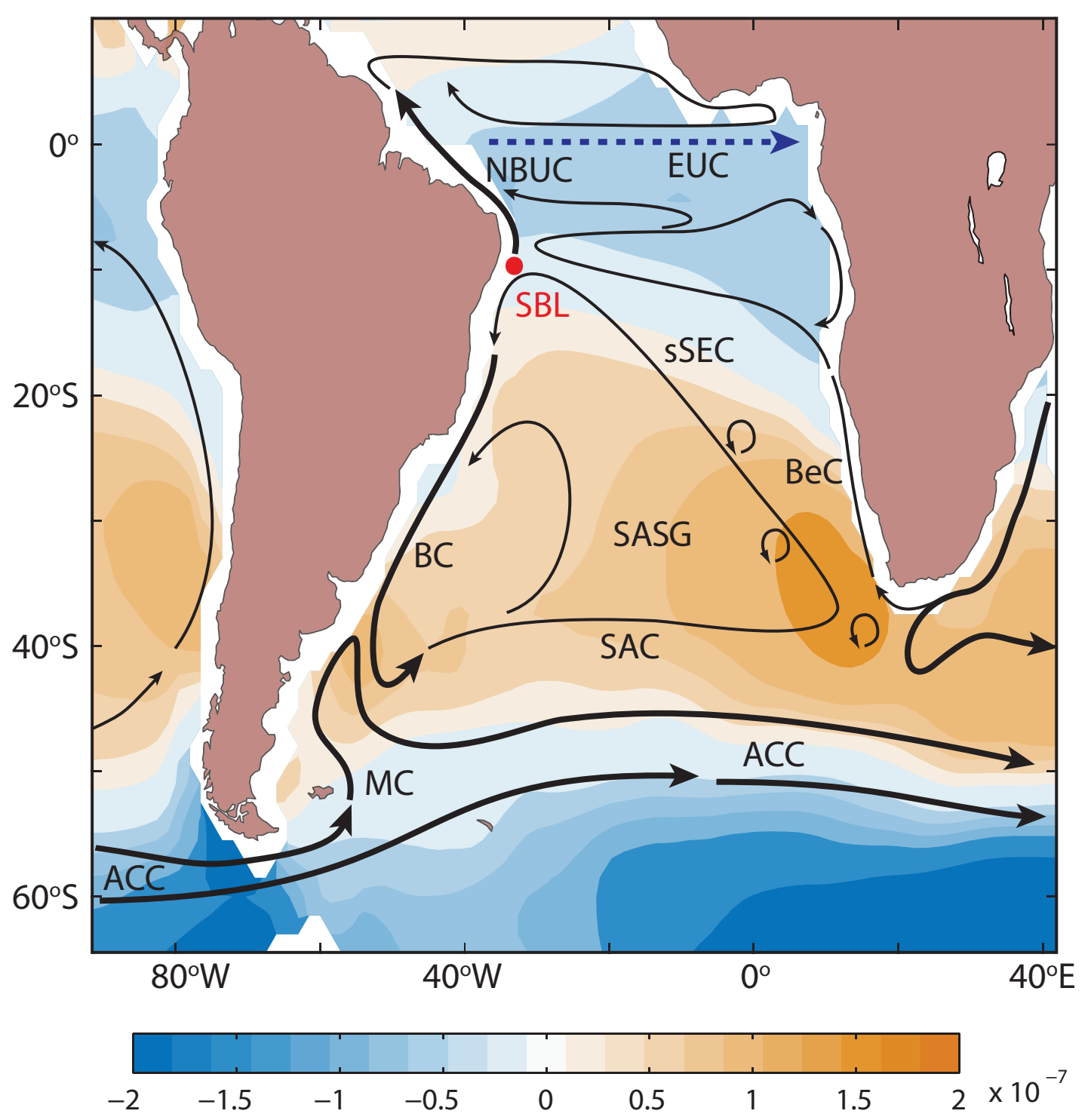

Figure 1 | Schematic representation of upper South Atlantic circulation. | Shown are the major wind-driven currents (black arrows) and mean Wind Stress Curl (N.m ${ }^{-3}$, background colors). Abbreviations are used for the South Atlantic Subtropical Gyre (SASG), Brazil Current (BC), South Atlantic Current (SAC), Benguela Current $(\mathrm{BeC})$, southern branch of the South Equatorial Current (SSEC), sSEC Bifurcation Latitude (SBL), North Brazil Undercurrent (NBUC), Equatorial Undercurrent (EUC), Antarctic Circumpolar Current (ACC) and Malvinas Current (MC). Adapted from Pontes et al. (2016) [Figure 1 from their Supplementary Information].

that can influence the SBL, which is also controlled by subsurface, thermohaline induced fluxes apart from the wind-forcing.

For this reason, besides investigating the SASG structure, this work attempts to elucidate the relative behaviour of its northern boundary, represented by the SBL, amidst ongoing 
global climate changes.

This work is organized as follows: Section 2 briefly describes the models and methods used. Section 3.1 presents a validation of the model results with reanalysis product data together with a characterization of the SSEC bifurcation. Section 3.2 addresses the main goal of this study, so that, initially, the long-term change of the SBL is assessed, then a general description of its annual cycle is provided. Section 3.3 and 3.4 show the results concerning the SASG basin-wide dynamics and the transport of the SAO currents, respectively, in which Section 3.4.3 relates the change in the SBL with the change in the transport of currents. Section 3.5 describes observed recent changes relative to a longer record, comprised by the Last Millennium (850-2005). And Section 4 provides a summary of the main conclusions.

\subsection{Scientific Hypothesis}

It has been suggested that mid-latitude gyres in all of the oceans have been affected by variability in the atmospheric forcing (Section 1.1 and references therein). The present study investigates this hypothesis for the SAO, by examining its basin-wide dynamics.

Furthermore, the long-term change of the SASG northern boundary, represented by the SSEC bifurcation, is addressed. Because it is included in the AMOC upper branch return flow, variations in the SBL may be attributable both to variations in the wind driven subtropical circulation and to altered thermohaline induced fluxes.

Therefore, in order to obtain a comprehensive picture of the possible changes in the upper SAO circulation, exploring only its gyre scale dynamics might not be sufficient. The SBL must be investigated apart, which includes considering both its subtropical southward component (the $\mathrm{BC}$ ) and the low-latitude northward NBUC.

Our hypothesis is that the SASG circulation is undergoing substantial changes along with worldwide subtropical gyres. The relative behaviour of the SBL amongst this scenario is still unknown. Our primary goal consists in elucidating this question.

\subsection{Objectives}

\subsubsection{Central Objective}

The central objective of this study is to answer two principal questions:

1) Is the SASG circulation changing, as inferred by the literature that signals in other ocean basins are likely to have a global expression (Roemmich et al., 2007) and/or manifest as a intensifying, southward shifting Southern Ocean super-gyre circulation (Cai, 2006)?

2) Does the SBL manifest a long-term trend and, if so, what is the mechanism primarily controlling it? 


\subsubsection{Explicit Objectives}

The explicit objectives are:

- Using simulation results from the ocean component of the Community Earth System Model (CESM) for the 1948-2015 period:

1) To first assess the SBL time series, derived from meridional velocity data, in order to identify significant linear trends;

2) To assess the SASG dynamics through signals in WSC, SSH, BSF and SST fields in order to detect variations in its counter-clockwise circulation strength and/or position plus spatial distribution along the basin;

3) To investigate the long-term change of the transport of the currents involved in the process of the SSEC bifurcation and how they relate to the previous results obtained.

- And using simulation results from the Last Millennium Ensemble experiment of the CESM for the 850-2005 period:

4) To provide a wider temporal perspective of the observed changes. 


\section{Methods}

\subsection{Data}

This study examines the simulation results of the ocean component of the Community Earth Sytem Model, version 1 (CESM1.0): the Parallel Ocean Program version 2 (POP2), which is hereafter referred to as CESM-OCN. The CESM-OCN data set is used to investigate changes which have occurred along the late 20th century into the beginning of the 21 st century.

Simulation results from the Last Millennium Ensemble experiment of the CESM (hereafter, CESM-LME), are also analyzed in order to provide a perspective from a longer record of climate variability, which represents an opportunity to understand how the climate system varied under "natural" conditions, before anthropogenic forcing became significant.

To validate the model results, a set of five ocean reanalysis products is used to compare the mean circulation fields and to access the accuracy in reproducing the main feature addressed by this study - the SSEC bifurcation.

More details concerning each data set mentioned above is provided in the following subsections.

\subsubsection{The Community Earth System Model}

The Community Earth System Model (CESM) (Hurrell et al., 2013) is a coupled global climate model that provides state-of-the-art computer simulations of the Earth's past, present, and future climate states. It is composed of four separate models simultaneously simulating the earth's atmosphere, ocean, land surface and sea-ice, and one central coupler component.

The coupled components include an atmospheric model (e.g., the Community Atmosphere Model, version 5 - Neale et al., 2010), a land-surface model (e.g., the Community Land Model, version 4 - Lawrence et al., 2009), an ocean model (the Parallel Ocean Program, version 2 - Smith et al., 2010), and a sea ice model (e.g., the Community Ice CodE - Hunke et al., 2015).

The central coupler coordinates the models and passes information between them. During the course of a CESM run, the model components integrate forward in time, periodically stopping to exchange information with the coupler. The coupler meanwhile receives fields from the component models, computes, maps, and merges this information, then sends the fields back to the component models. The coupler brokers this sequence of communication interchanges and manages the overall time progression of the coupled system.

In this study, CESM-OCN refers exclusively to the CESM ocean component; while CESM-LME refers to simulation results from the Last Millennium Ensemble, which employs version 1 of CESM with the configuration of individual model components given as the above examples. 


\subsubsection{CESM-OCN}

The CESM ocean component is a level-coordinate ocean general circulation model that solves the three-dimensional primitive equations for ocean dynamics. The version used is based on the POP version 2.1 of the Los Alamos National Laboratory. The ocean model has a $1^{\circ}$ horizontal resolution and 60 vertical levels. For the details of the numerical methods and discretization used, the reader is referred to "The POP Reference Manual" (Smith et al., 2010).

\subsubsection{CESM-LME}

The CESM Paleoclimate Working Group at NCAR conducted a series of Last Millennium community experiments, referred to as the Last Millennium Ensemble (LME). The experiment includes a set of simulations forced with the transient evolution of solar intensity, volcanic emissions, greenhouse gases, aerosols, land use conditions, and orbital parameters, both together and individually; for the period 850-2005. It employs version 1.1 of CESM with the CAM version 5 [CESM1(CAM5); Hurrell et al., 2013]. The CESM-LME uses 2-degree resolution in the atmosphere and land components and 1-degree resolution in the ocean and sea ice components. Please refer to the overview paper of the Last Millennium Ensemble Project (Otto-Bliesner et al., 2016) for more details.

To investigate the long-term change in the SBL and in the SASG dynamics, the present study examines the ensemble average of 10 simulations with the full-set of external forcings.

\subsubsection{Ocean Reanalysis Products}

In order to validate the CESM data-set, we used five ocean reanalysis products for comparison: the European Center for Medium-Range Weather Forecasts (ECMWF) ocean analysis/reanalysis system 4 (ORAS4), the Geophysical Fluid Dynamics Laboratory (GFDL), the Simple Ocean Data Assimilation version 2.1.6 (SODA216), the Global Ocean Data Assimilation System (GODAS) and the Climate Forecast System Reanalysis (CFSR) from the National Centers for Environmental Prediction (NCEP) (Table 1).

Table 1: Time period, horizontal resolution and number of vertical layers above $1000 \mathrm{~m}$ of the 5 ocean reanalysis products.

\begin{tabular}{cccc}
\hline Product & Period & Horiz. Resolution & Vertical Layers $\mathbf{1 0 0 0 ~ \mathbf { ~ }}$ \\
\hline ORAS4 & $1960-2010$ & $1^{\circ} \times 1^{\circ}$ & 26 \\
GFDL & $1961-2010$ & $1^{\circ} \mathrm{X}-$ & 34 \\
SODA216 & $1960-2008$ & $0.5^{\circ} \times 0.5^{\circ}$ & 22 \\
GODAS & $1980-2010$ & $1^{\circ} \times 1 / 3^{\circ}$ & 31 \\
CFSR & $1980-2010$ & $0.5^{\circ} \times 0.5^{\circ}$ & 31
\end{tabular}

${ }^{*}$ The latitudinal resolution of the GFDL reanalysis varies between approximately $0.33^{\circ}$ near the equator to $1^{\circ}$ near $30^{\circ} \mathrm{S}$. 


\subsection{Variables and indices}

This study covers a domain ranging from $55^{\circ} \mathrm{S}$ to the equator, between South America and Africa $\left(70^{\circ} \mathrm{W}-20^{\circ} \mathrm{E}\right)$. The analysis are based on the data-sets of zonal and meridional total velocities (UVEL, VVEL), zonal and meridional wind stress (TAUX, TAUY), Sea Surface Height (SSH), Barotropic Stream Function (BSF) and Sea Surface Temperature (SST).

The Wind Stress Curl (WSC) field, was derived from TAUX and TAUY data; and finally, the Sverdrup Transport (hereafter, SVT) field was derived by zonally integrating the WSC field from the eastern to the western basin (e.g., Stewart, 2008).

\subsubsection{SBL definition}

The SBL index was obtained by first zonally averaging the meridional velocities within a $4^{\circ}$ longitude band off the South American coast and finding, at each time step, the latitude of transition from negative (southward) to positive (northward) velocities, i.e., the zero meridional velocity, in each level of interest of the linearly interpolated vertical profile (at $25 \mathrm{~m}$ intervals).

Since the focus of this study is the surface layer, which is in direct contact with the major forcings of upper ocean circulation, only the SBL time series at $25 \mathrm{~m}$ and at $100 \mathrm{~m}$ are displayed. We construct monthly time series for these individual upper levels, instead of averaging the bifurcation latitude over a whole vertical layer. The poleward shift with depth of the SSEC bifurcation in the SAO is more pronounced than that of the bifurcations from the North Pacific, South Pacific and South Indian oceans (hereafter, NPO, SPO and SIO). Our results show that the SBL poleward tilting for the top $400 \mathrm{~m}$ is at least of $10^{\circ} \mathrm{S}$ (Section 3.1), while (Chen et al., 2014) find a corresponding shift of only $1.5^{\circ} \mathrm{S}$ for the SBL off Madagascar, in the SIO. Likewise, R2007 find a shift of approximately $14^{\circ}$ of latitude in the top $1000 \mathrm{~m}$, in contrast to the shift of the NBL in the NPO, which does not exceed $8^{\circ}$ of latitude (compare Fig. 3 in R2007 with Fig. 11 in Qu and Lukas, 2003); consequently, the SBL varies a great deal within vertical layers.

As argued by Chen and Wu (2012) with regard to the Pacific NBL, the bifurcation latitude defined by meridional velocity is not sensitive to different averaging longitudes. A band of $4^{\circ}$ longitude was adopted in order to favour WBCs representation in conjunction with the SSEC bifurcation vertical profile in Section 3.1. A $2^{\circ}$ longitude band, for instance (as used by R2007) yielded virtually the same results.

\subsubsection{SASG dynamical indices}

Changes in the SASG dynamics were inferred from variations in WSC, SSH, BSF and SST fields (Figure 2). However, alternative approaches were applied to the WSC, SSH and BSF fields, whose spatial distributions are given through enclosed contours within the South Atlantic basin, rather than meridionally varying ones, as is the case of the SST field.

The SVT field was used as an auxiliary tool, when suitable, in order to consistently 
capture the relevant changes in WSC field, once the zonal integration removes small scale zonal variability, retaining the large-scale signal in which we are truly interested in. The SVT field is shown as background colors in Figure 9, at Section 3.3.

Thus, the aforementioned fields were analyzed in terms of their intensity (magnitude) and spatial fluctuations. More specifically, we aimed to keep track of the temporal evolution 1) of their varying strength inside the dynamical rims given by the zero contours (Figure 2); plus, 2) of the varying position of the gyre boundaries given by the zero contours.
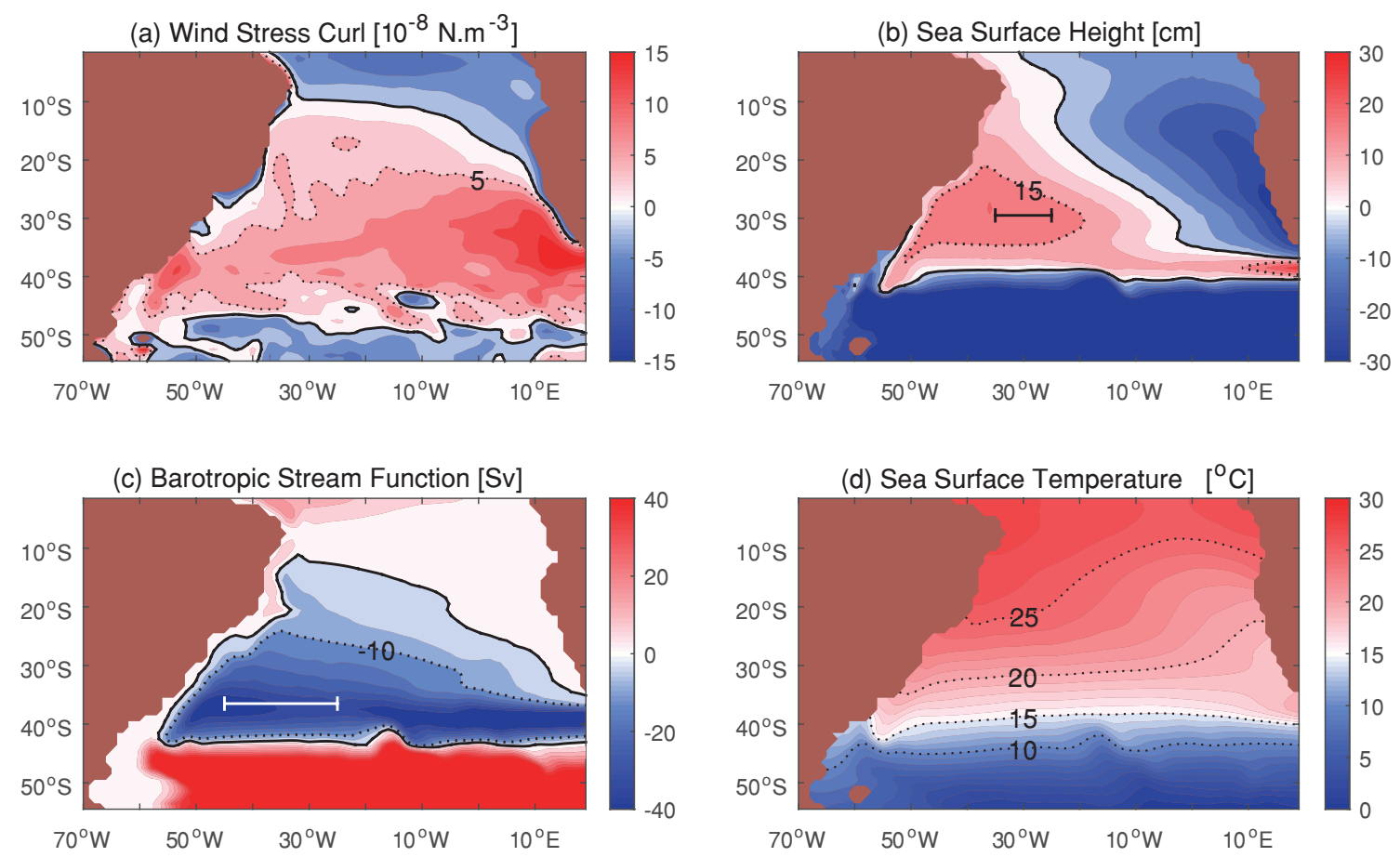

Figure 2 | Large-scale SAO dynamical fields. | Climatological (a) WSC, (b) SSH, (c) BSF and (d) SST. Contours are every (a) $2.5 \times 10^{-8} \mathrm{~N} \cdot \mathrm{m}^{-3}$, (b) $5 \mathrm{~cm}$, (c) $5 \mathrm{~Sv}$ and (d) $1^{\circ} \mathrm{C}$. Zero contours which delimitate positive (negative) WSC/SSH (BSF) fields are indicated by black solid lines. Also highlighted by black dashed lines are the (a) $5 \times 10^{-8} \mathrm{~N} \cdot \mathrm{m}^{-3}$, (b) $15 \mathrm{~cm}$, (c) $-10 \mathrm{~Sv}$ and (d) $10^{\circ} \mathrm{C}$, $15^{\circ} \mathrm{C}, 20^{\circ} \mathrm{C}, 25^{\circ} \mathrm{C}$ contours; used as parameters to perform index calculations.

\section{Intensity indices:}

The indices to monitor the varying intensity of the large-scale WSC, SSH and BSF fields within a) the zero contour, plus b) the isocontours of $>\left(5 \times 10^{-8} \mathrm{~N} \cdot \mathrm{m}^{-3}\right),>(15 \mathrm{~cm})$ and $<(-10 \mathrm{~Sv})$, indicated in Figure $2 \mathrm{a}, 2 \mathrm{~b}$ and $2 \mathrm{c}$, respectively, were calculated as follows:

- VARavg $(t)=$ time series of mean WSC/SSH/BSF within the zero contour ${ }^{2}$ inside the South Atlantic domain (as in Fig. 2);

- Area $(t)=$ time series of the corresponding area within the zero contour of each field - which can vary, by contraction or expansion depending on the evolving dynamics.

\footnotetext{
${ }^{2}$ One should note that, consequently, only positive (negative) values of WSC and SSH (BSF) were considered for these calculations.
} 
- VARavg/Area(t) $=$ resulting time series of the mean value of the respective variable within the contour, divided by the corresponding area surrounded by the contour.

The same calculation was conducted for the $>\left(5 \times 10^{-8} \mathrm{~N}^{-3} \mathrm{~m}^{-3}\right),>(15 \mathrm{~cm})$ and $<(-10 \mathrm{~Sv})$ contours (in the case of the WSC, SSH and BSF fields, respectively), which are all placed inside the zero contour of each dynamical field.

With regard to accuracy, the VARavg/Area(t) index consists of a more reliable measure of the varying strength of enclosed WSC, SSH and BSF which modulates the gyre circulation. It considers the variables' magnitude (mean value within the contour) relative to its corresponding area in each time step. The anomalies (with respect to the annual cycle) are presented in Figure 11 from Section 3.3.

\section{Displacement indices:}

The meridional displacement of the dynamical fields was also monitored. Time series of their boundaries were derived exclusively in regions where there were considerably high meridional gradients on both northern and southern limits of the zero contour. In view of that, indices of the latitudinal position of the zero contour were generated for:

(a) the SVT, at the northern boundary and at the first grid point off the South American coast (i.e., the zero zonally integrated WSC line);

(b) the $\mathrm{SSH}$, at the southern boundary and both at a western $\left(40^{\circ}-20^{\circ} \mathrm{W}\right)$ and an eastern $\left(10^{\circ} \mathrm{W}-10^{\circ} \mathrm{E}\right)$ portion of the basin; and

(c) the BSF, at the southern boundary and both at a western $\left(50^{\circ}-20^{\circ} \mathrm{W}\right)$ and an eastern $\left(10^{\circ} \mathrm{E}\right)$ portion of the basin, as well (the variability at $10^{\circ} \mathrm{W}$ and $0^{\circ}$ is highly restricted by the meridional gradient south of the zero line).

These time series are presented in Figure 15. Hereinafter, the zero contours in general are referred to as WSCO, SVTO, SSHO and BSFO.

\section{Core indices:}

Time series of the maximum zonally averaged WSC/SSH/|BSF and of the corresponding latitude of the maximum were also derived - in order to represent a measure of the dynamical central cores of the gyre.

The maximum WSC was estimated for the whole basin extent $\left(70^{\circ} \mathrm{W}-20^{\circ} \mathrm{E}\right)$, while the zonal bands used to derive maximum SSH and BSF are indicated in Figure $2 \mathrm{~b}$ and $2 \mathrm{c}$, respectively. These time series are presented in Figure 13 from Section 3.3. 


\subsection{Volume transports}

The total transport of the ocean currents (the SSEC at $30^{\circ} \mathrm{W}$, the $\mathrm{BC}$ at $28.5^{\circ} \mathrm{S}$ and the NBUC at $6.5^{\circ} \mathrm{S}$ ) was derived by horizontally and vertically integrating the zonal (SSEC) and meridional $(B C, N B U C)$ velocities ${ }^{3}$, following Equation 1 , where $d x$ and $d z$ are the horizontal and vertical dimensions of the model cell. For the NBUC and the BC, the zonal length of the section was based on the climatological width of the currents. In the case of the westward flowing SSEC, which is broader, the latitude band of $6^{\circ}-22^{\circ} \mathrm{S}$ was adopted, following R2007.

$$
\mathrm{T}_{\mathrm{Sv}}(\mathrm{x}, \mathrm{t})=\iint_{-H}^{0} \mathrm{v}(\mathrm{x}, \mathrm{t}) \mathrm{dz} \mathrm{dx}
$$

The barotropic transports time series were derived from the two-dimensional BSF field (at the same locations as total transports plus additional locations specified in Section 3.4.2).

\subsubsection{MOC}

The time series of the MOC streamfunction were computed for the latitudes of $6.5^{\circ} \mathrm{S}$ and $26.5^{\circ} \mathrm{N}$. The MOC represents the large-scale motion of the oceans, including thermohaline induced fluxes as well as wind-driven circulation, and can be defined as vertically and zonally integrated meridional velocity in an east-west section across an ocean basin, at a given latitude (e.g., Cunningham and Marsh, 2010):

$$
\Psi \operatorname{MOC}(y, z, t)=\int_{x_{e}, y}^{x_{w}, y} \int_{-H}^{z} v(x, y, z, t) d z d x
$$

where $\mathbf{v}(\mathbf{x}, \mathbf{y}, \mathbf{z}, \mathbf{t})$ is the meridional velocity at longitude $\mathbf{x}$, depth $\mathbf{z}$, time $\mathbf{t}$ and latitude $\mathbf{y} ;-\mathbf{H}$ and $\mathbf{z}$ are the vertical limits of integration (from a given depth to the surface) and $\mathbf{x}_{e}, \mathbf{y}$ and $\mathbf{x}_{w}, \mathbf{y}$ are the eastern and western boundaries at a given latitude.

At $6.5^{\circ} \mathrm{S}$, the MOC was calculated so that it could be compared with the western boundary NBUC transport, at the same latitude; and the latitude of $26.5^{\circ} \mathrm{N}$ is chosen for being the location where there is a continuous observing system since 2004 (the RAPID-MOC - McCarthy et al., 2015), which measures the main flux components that represent the AMOC strength (e.g., Rayner et al., 2011). For both latitudes, the MOC streamfunction is vertically integrated above 1000-m.

\footnotetext{
${ }^{3}$ Only positive (negative) velocities were used for the NBUC (BC, SSEC) transport calculation.
} 


\subsection{Low-pass filtering}

In order to reduce random noise while retaining a sharp step response of the time series (extracting, therefore, the low-frequency component), a multiple-pass moving average filter was applied, which involves passing the input signal through a moving average filter twice or more times (e.g., Smith, 1997).

The moving average filter (or running-mean) is the most common filter in Digital Signal Processing, used to smooth data by replacing each data point with the average of the neighbouring data points defined within the span.

When not mentioned, all the time series were smoothed 3 times using a 15-month moving average. This procedure compared to the use of regular annual means, for instance, does not change our results. In a few exceptions, a length of 35-month was used instead.

\subsection{Linear trends, Significance Testing and Correlations}

The long-term trends were estimated by least squares fit and their statistical significance were estimated with the Mann-Kendall test (Kendall, 1975; Mann, 1945). This is a non-parametric method less affected by outliers sometimes contained in data (e.g., Tokinaga and Xie, 2011). If the Student's $t$-test is applied for the same data, our conclusions do not change.

To quantify the linear relations between time series, the Pearson's correlation coefficient was used (see Rodgers and Nicewander, 1988, for detailed information). To determine if the correlations are significant a t-test was applied, at the $95 \%$ confidence level. All the correlations mentioned in this study are statistically significant. 


\section{Results}

\subsection{Validation and Characterization}

To investigate how well the models simulate the SSEC bifurcation and the scenario in which it is inserted, their results were compared to those of the ocean reanalysis products described in Section 2.1.4. The comparisons are made based on the periods covered by the reanalysis products, displayed in Table 1; on the full 1948-2015 period for CESM-OCN and on the interval of 1960-2010 for CESM-LME.

The meridional velocity averaged within a $4^{\circ}$ longitude band off the South American coast is compared (Figure 3). As described in Section 2.2.1, the SBL is defined as the point where the zonally averaged meridional velocity is zero, denoted by the thick-black contours. All data sets seem to depict well the depth dependence of the bifurcation latitude, although slightly different configurations of the SSEC bifurcation vertical profile can be noted between them. 
(a) ORAS4

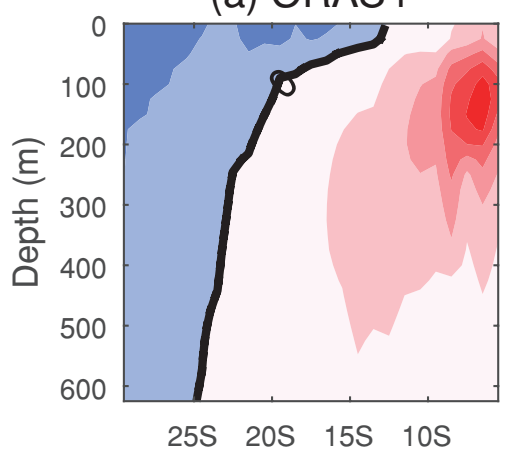

(d) GODAS

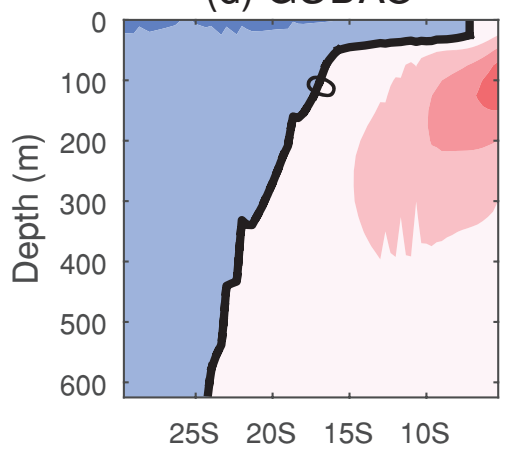

(g) CESM-LME

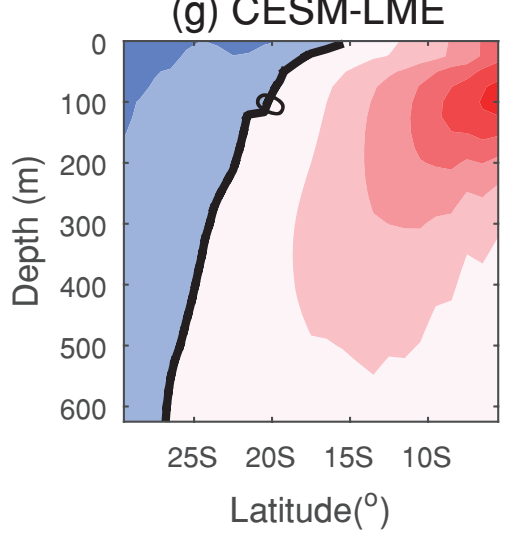

(b) GFDL

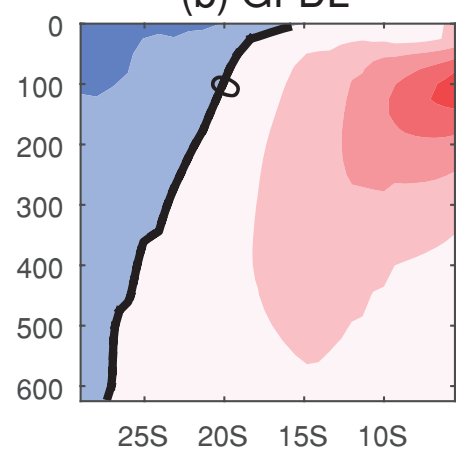

(e) CFSR

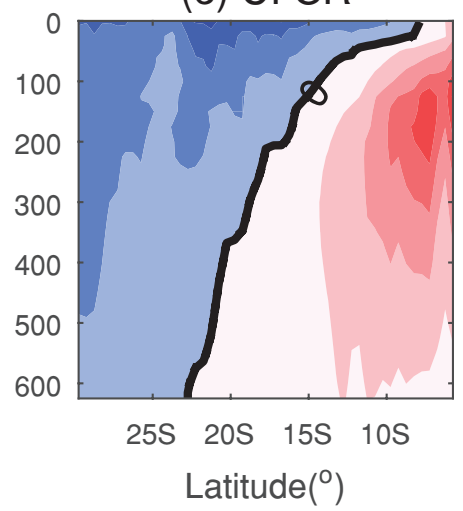

(c) SODA216

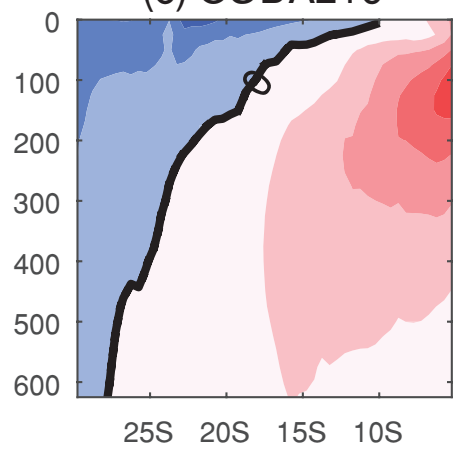

(f) CESM-OCN

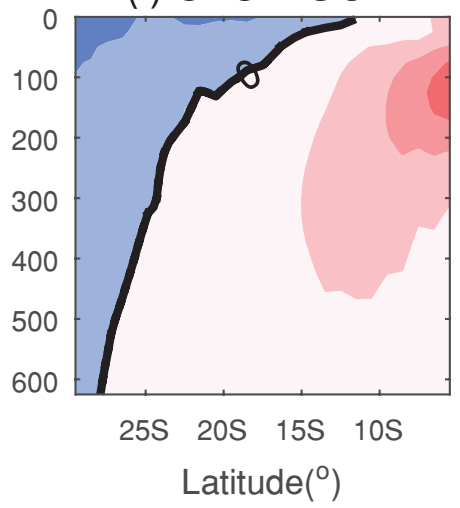

Figure 3 | SSEC bifurcation vertical profile from the reanalysis products and model results. Mean meridional velocity $\left(\mathrm{m} . \mathrm{s}^{-1}\right)$ averaged over the western boundary layer $\left(<4^{\circ}\right.$ from the coast) from ocean reanalysis products (a-e) and from model results (f-g). Positive (negative) values indicate northward (southward) flow associated with the NBUC (BC), and the contour of zero velocity represents the bifurcation of the SSEC.

From hydrographic observations and numerical model results, R2007 characterized the SSEC bifurcation vertical structure at the western boundary, providing a description of its annual mean depth dependence. The authors showed that the bifurcation occurs at about $10^{\circ}-14^{\circ} \mathrm{S}$ in the top $100 \mathrm{~m}$ and shifts poleward with increasing depth, reaching $27^{\circ} \mathrm{S}$ at $1000 \mathrm{~m}$ (Figure 4). 
(a) Observation

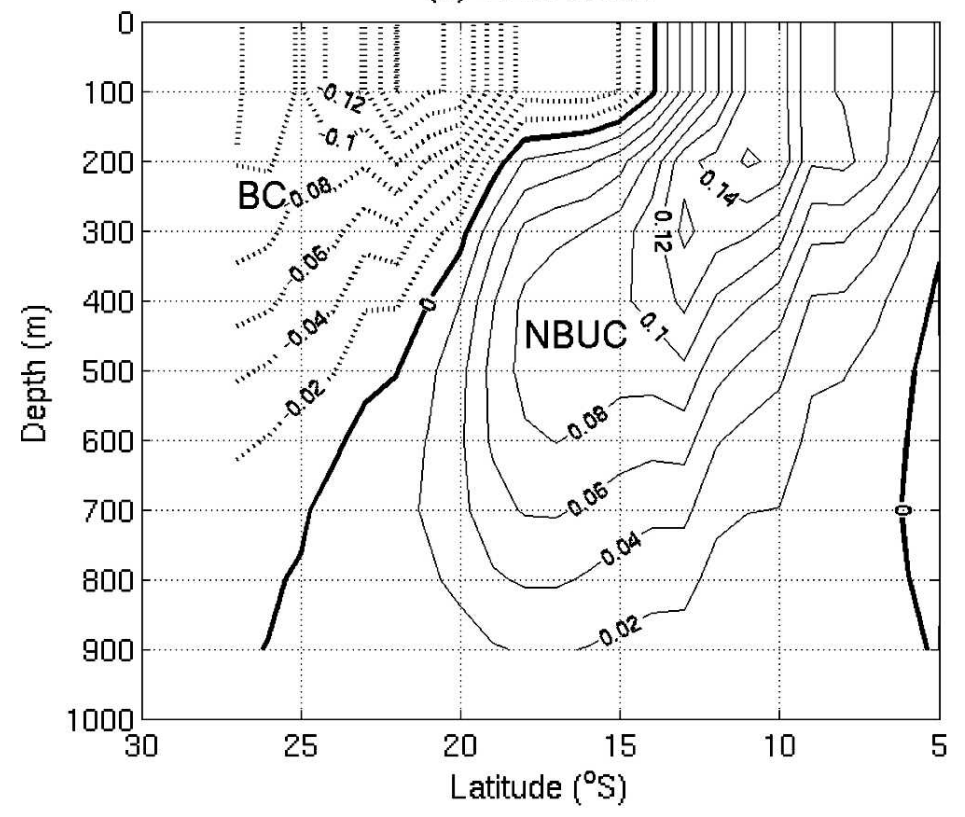

(b) Model

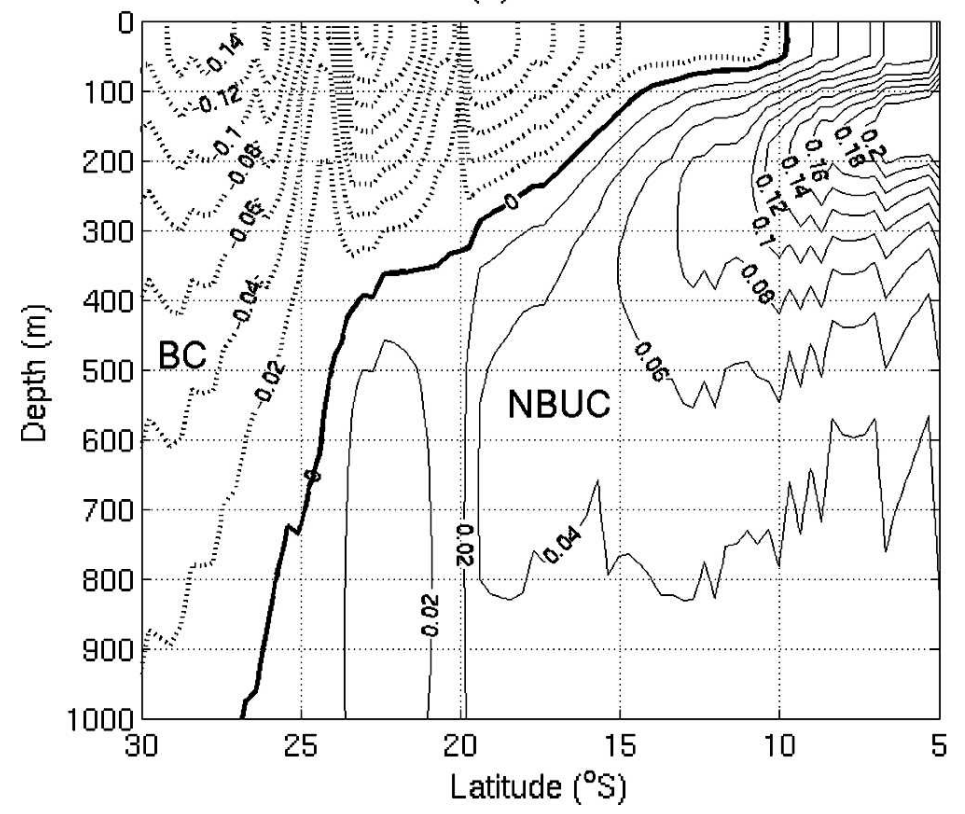

Figure 4 | SSEC bifurcation vertical profile, extracted from Rodrigues et al. (2007). | Annual mean (a) geostrophic meridional velocity from observations and (b) total meridional velocity from model results. The velocities $\left(\mathrm{m}^{-1} \mathrm{~s}^{-1}\right)$ are averaged within a $2^{\circ}$ longitude band off the South American coast.

Among the reanalysis products that were examined, the structure that more closely resembles the contour from R2007 hydrographic observations is the one reproduced by ORAS4. A previous investigation which evaluated the products' performance in terms of the mean circulation field for different levels in comparison to the available observations of R2007 (not shown), also suggested that ORAS4 better captures the dynamics of the SBL.

ORAS4 also captures reasonably well the Pacific SBL interannual variation, as shown by Yamagami and Tozuka (2015). The authors compare the SBL derived from ORAS4 with the 
one calculated from the surface meridional velocity obtained from AVISO derived data ${ }^{4}$.

The mean SBL for individual levels up to $600 \mathrm{~m}$ is listed in Table 2. Despite some small differences, all data-sets reproduce the poleward tilting of the SSEC bifurcation with increasing depth. The total shift up to $600 \mathrm{~m}$ of the R2007 observations and of ORAS4, CESM-OCN and CESM-LME are within the range of $9^{\circ}-13 \cdot 1^{\circ}$.

Table 2: SBL values obtained by R2007 from hydrographic observations; derived from ocean reanalysis products and obtained from the CESM-models results.

\begin{tabular}{ccccccc}
\hline Level & surface & $\mathbf{1 0 0} \mathrm{m}$ & $\mathbf{2 0 0} \mathrm{m}$ & $\mathbf{4 0 0} \mathrm{m}$ & $\mathbf{6 0 0} \mathrm{m}$ & Total shift \\
\hline Obs. & $14^{\circ} \mathrm{S}$ & $14^{\circ} \mathrm{S}$ & $18.6^{\circ} \mathrm{S}$ & $21^{\circ} \mathrm{S}$ & $23.6^{\circ} \mathrm{S}$ & $9.6^{\circ}$ \\
ORAS4 & $13^{\circ} \mathrm{S}$ & $19.6^{\circ} \mathrm{S}$ & $21.3^{\circ} \mathrm{S}$ & $23.3^{\circ} \mathrm{S}$ & $24.7^{\circ} \mathrm{S}$ & $11.7^{\circ}$ \\
GFDL & $18.3^{\circ} \mathrm{S}$ & $20.1^{\circ} \mathrm{S}$ & $21.2^{\circ} \mathrm{S}$ & $25.5^{\circ} \mathrm{S}$ & $27.1^{\circ} \mathrm{S}$ & $8.8^{\circ}$ \\
SODA216 & $13^{\circ} \mathrm{S}$ & $18.1^{\circ} \mathrm{S}$ & $22.1^{\circ} \mathrm{S}$ & $25.1^{\circ} \mathrm{S}$ & $27.6^{\circ} \mathrm{S}$ & $14.6^{\circ}$ \\
GODAS & $7.2^{\circ} \mathrm{S}$ & $16.9^{\circ} \mathrm{S}$ & $19^{\circ} \mathrm{S}$ & $22.2^{\circ} \mathrm{S}$ & $24.1^{\circ} \mathrm{S}$ & $16.9^{\circ}$ \\
CFSR & $8.4^{\circ} \mathrm{S}$ & $14.4^{\circ} \mathrm{S}$ & $16.5^{\circ} \mathrm{S}$ & $20.5^{\circ} \mathrm{S}$ & $22.6^{\circ} \mathrm{S}$ & $14.2^{\circ}$ \\
CESM-OCN & $14.7^{\circ} \mathrm{S}$ & $19^{\circ} \mathrm{S}$ & $23.3^{\circ} \mathrm{S}$ & $25.7^{\circ} \mathrm{S}$ & $27.8^{\circ} \mathrm{S}$ & $13.1^{\circ}$ \\
CESM-LME & $17.8^{\circ} \mathrm{S}$ & $20.3^{\circ} \mathrm{S}$ & $22.3^{\circ} \mathrm{S}$ & $24.9^{\circ} \mathrm{S}$ & $26.8^{\circ} \mathrm{S}$ & $9^{\circ}$ \\
\hline
\end{tabular}

* Hydrographic observations from R2007: geostrophic velocities determined from dynamic heights relative to $1000 \mathrm{dbar}$, calculated with an annual mean climatology of temperature and salinity constructed from observations [quality-controlled CTD and bottle data obtained from HydroBase (Curry 1996)]. The authors' calculations do not include the Ekman current, which would affect the bifurcation latitude near the surface. They clarify that adding the Ekman currents to the geostrophic currents (calculated from observations) moves the bifurcation latitude northward by about $1^{\circ}$ (i.e., the bifurcation occurs at $13^{\circ} \mathrm{S}$ at the surface).

Considering the large scale climatology, a good correspondence between the SBL and the zero zonally integrated WSC line is expected. That is because, according to Sverdrup balance (Pedlosky, 1996), the sSEC should bifurcate along this line - at the latitude where no western boundary current compensates the total interior transport. Figure 5 demonstrates this relation between the bifurcation latitude in the upper ocean and the large scale basin-integrated WSC, showing the mean horizontal flow field, vertically integrated over the top $50 \mathrm{~m}$ as vectors. The ORAS4 product, CESM-OCN and CESM-LME reasonably attain to the Sverdrup relation, as can be seen in Figure $5 \mathrm{a}, \mathrm{f}, \mathrm{g}$.

\footnotetext{
${ }^{4}$ It has been remarked by the authors that, since ORAS4 assimilates observed sea level anomalies, it is not completely independent of the AVISO derived data.
} 
(a) ORAS4

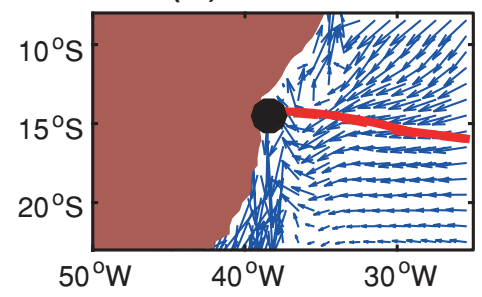

(b) GFDL

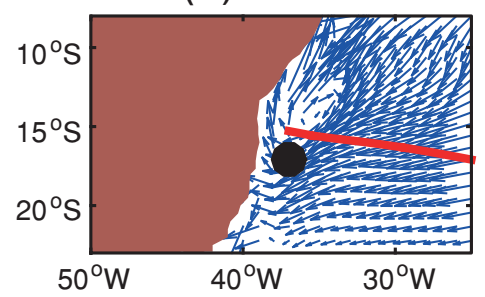

(c) SODA216

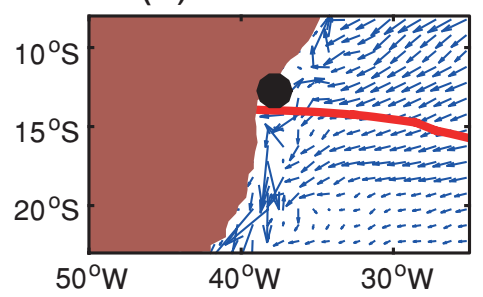

(d) GODAS

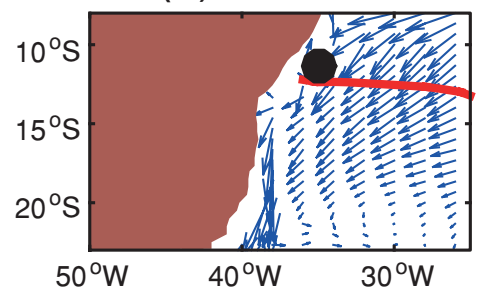

(e) CFSR

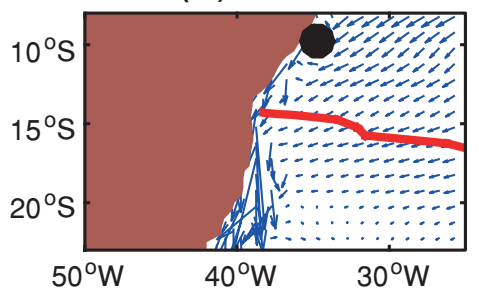

(f) CESM-OCN

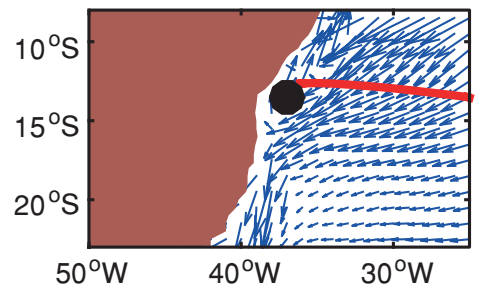

(g) CESM-LME

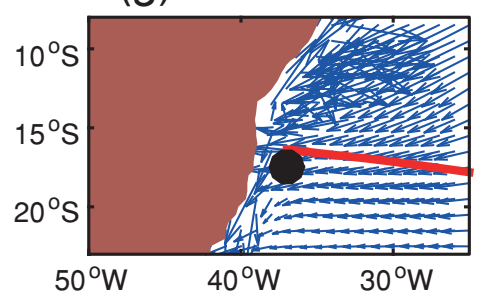

Figure 5 | Depth-integrated flow over the upper 50 m (blue vectors). | Derived from ocean reanalysis products: (a) ORAS4, (b) GFDL, (c) SODA216, (d) GODAS, (e) CFSR; and from model results: (f) CESM-OCN and (g) CESM-LME. The dark dots indicate the mean position of the SBL, and the red lines indicate the zero contour of the wind stress curl integrated from east to west.

Therefore, the simulation results from CESM-OCN and CESM-LME are similar to the results derived from ORAS4 and to R2007 hydrographic observations, proving that the models simulate well the SSEC bifurcation and the region of study.

These results also agree with the available literature. From hydrographic data, Stramma and England (1999) showed that the bifurcation latitude is $16^{\circ} \mathrm{S}$ in the nearsurface layer (top $100 \mathrm{~m}$ ), $20^{\circ} \mathrm{S}$ in the South Atlantic Central Water (SACW) layer (100-500 m), and 26 $\mathrm{S}$ in the intermediate layer (500-1200 m). Using isobaric RAFOS floats, Boebel et al. (1999) showed that the Return Current [analog to the SEC, but within the Antarctic Intermediate Water (AAIW) layer] reaches the South American coast at about $28^{\circ} \mathrm{S}$ (called by the authors the Santos Bifurcation). Using data from the World Ocean Circulation Experiment (WOCE) hydrographic section A17 taken during the austral summer of 1994, Wienders et al. (2000) estimated the transport of the SEC and its bifurcation latitude for several isopycnal layers: the SEC bifurcation latitude is $14^{\circ} \mathrm{S}$ at the surface, $24^{\circ} \mathrm{S}$ in the $26.7-26.9$ layer $(400-500 \mathrm{~m})$, and nearly constant around $26^{\circ}-28^{\circ} \mathrm{S}$ in the 
AAIW and Upper Circumpolar Water (UCPW: 600-1200 m). These results should be interpreted with caution because they are based on a single hydrographic section taken $6^{\circ}-10^{\circ}$ from the western boundary. In the simulations by Harper (2000), the bifurcation point in the near-surface layer at the western boundary of the South Atlantic occurs at $18^{\circ} \mathrm{S}$; and in those by MalanotteRizzoli et al. (2000), at $17^{\circ} \mathrm{S}$. From the results of two high-resolution ocean global circulation models OGCMs (Hybrid Coordinate Ocean Model - HYCOM and Ocean Circulation and Climate Advanced Modeling Project - OCCAM), Pereira et al. (2014) found that the latitude of bifurcation of the zonal flows reaching the coast (analog to the SEC), is $13^{\circ}-15^{\circ} \mathrm{S}$ for the Tropical Water, $22^{\circ} \mathrm{S}$ for the Central Water, $28^{\circ}-30^{\circ} \mathrm{S}$ for the Antarctic Intermediate Water. Cirano et al. (2006), using data from the global circulation model Ocean Circulation and Climate Advanced Modelling Project (OCCAM), found that the bifurcation occurs between $9^{\circ}-15^{\circ} \mathrm{S}$ in the TW $(0-116 \mathrm{~m})$, migrating to $25^{\circ} \mathrm{S}$ in the SACW (116-657 $\mathrm{m}$ ) and between $25^{\circ}-30^{\circ} \mathrm{S}$ in the AAIW (657-1234 $\mathrm{m}$ ).

\subsection{Long-term change of the SBL}

Having validated the main features associated with the SSEC bifurcation, it is possible to explore the temporal evolution of the SBL.

To better establish a linkage between changes in the SBL and changes in surface dynamical fields (i.e., WSC, SSH, SST), we focus on the SBL right below the surface, at $25 \mathrm{~m}$ depth (hereinafter referred to as $S S B L$ ). The smoothed time series reveals well-defined low-frequency variability (Figure 6a).

Still, an apparent feature depicted in Figure $6 \mathrm{a}, \mathrm{c}$ is the long-term trend of the sSBL. From 1948 to 2015 , the mean position of the SSBL has shifted southward from $11.5^{\circ} \mathrm{S}$ to $15^{\circ} \mathrm{S}$, at a rate of $0.051^{\circ} \mathrm{S} \mathrm{yr}^{-1}$. Yet, if one considers the period from $1970 \mathrm{on}$, whereupon the southward migration is more clearly defined, the corresponding values are of $11^{\circ} \mathrm{S}$ to $16^{\circ} \mathrm{S}$, at a rate of $-0.108^{\circ} \mathrm{yr}^{-1}$. This southward shift is further supported by the linear trend derived from ORAS4 reanalysis data (green dots), which is of $-0.019^{\circ} \mathrm{yr}^{-1}$. All trends shown are statistically significant at the $95 \%$ confidence level. Periods between solid (1965-1980) and dotted (2000-2015) vertical lines in Fig. 6a were used to average the SBL vertical profile in Fig. $6 \mathrm{~b}$ - elucidating the poleward displacement at the surface and also giving a spatial perspective of the change with increasing depth. It is observed that below approximately $100 \mathrm{~m}$, the scenario reverts to a slight northward migration along the SBL vertical extent, characterizing a decrease in its poleward shift with depth and thus a smaller depth-dependence of the subtropical gyre circulation.

The sSBL monthly anomalies are shown in Figure 6c, with the aforementioned 19702015 abrupt linear trend highlighted in yellow.

Figure $6 \mathrm{~d}$ gives a clear notion of the difference between the mean annual cycle of the periods marked in between solid/dotted vertical lines in Fig. 6a. Besides a southward displacement of the position of each climatological month, a subtle change in their distribution is also observed: the month of northernmost position switches from November to December. 

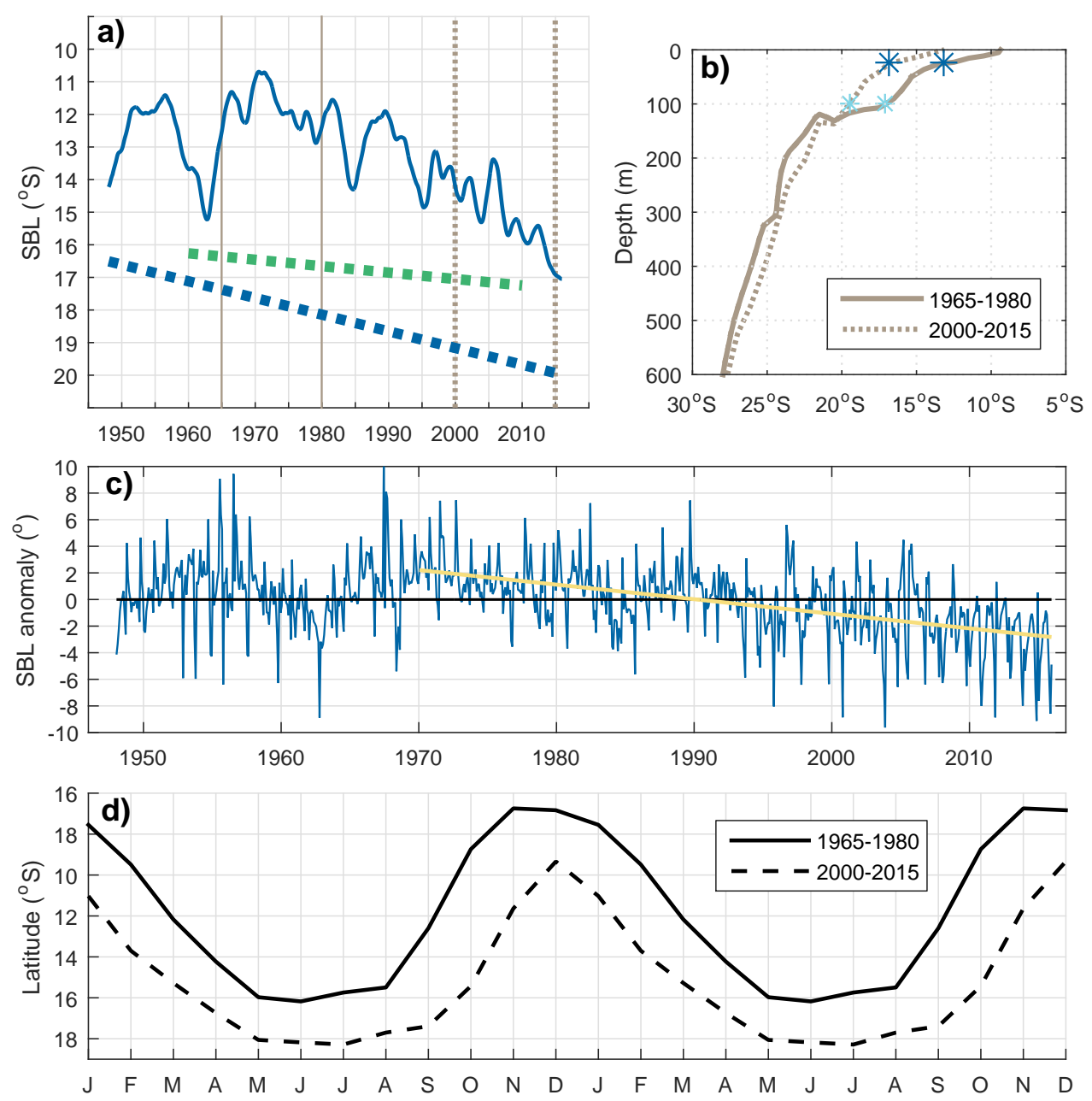

Figure 6 | Long-term change of the SBL. | (a) Low-pass-filtered (15-month multi-running mean) SBL time series. The blue (green) dots indicate the linear trend for the CESM-OCN (ORAS4) during 1948-2015 (1960-2010). Both linear trends are subtracted by $5^{\circ}$ for clarity. Solid (dashed) vertical lines indicate the period of northerly (southerly) SSBL used to average the SSEC bifurcation vertical profile in $6 \mathrm{~b}$ and annual cycle in $6 \mathrm{~d}$. (b) Vertical profile of the sSEC bifurcation (i.e., contour of zero meridional velocity averaged within a $4^{\circ}$ longitude band off the South American coast) averaged during years of northerly SSBL (1965-1980 - solid line) and southerly SSBL (2000-2015 - dashed line), according to the time series in 6a. Blue (light blue) asterisks indicate the level used to derive the SSBL time series in $6 a$ (the SBL time series at $100 \mathrm{~m}$ in Fig. 7). (c) SSBL monthly anomalies (i.e., annual cycle was removed). Yellow solid line indicates the linear trend for 1970-2015. (d) Climatological SSBL for years of northerly (solid line) and southerly (dashed line) bifurcation position, also according to the time series in $6 \mathrm{a}$. For clarity, the monthly values are plotted for a 2-year time period.

The SBL at $100 \mathrm{~m}$ undergoes considerable multidecadal oscillations (Figure 7). Its overall linear trend (not shown) also yields a southward migration $\left(-0.022^{\circ} \mathrm{yr}^{-1}\right)$ albeit smaller than at the surface (recall Fig. 6b). Considering the period after the 80 's, the long-term total shift is of $-1.94^{\circ}$ (or $-0.054^{\circ} \mathrm{yr}^{-1}$, dashed light blue line below the time series - statistically significant at the $95 \%$ confidence level). 


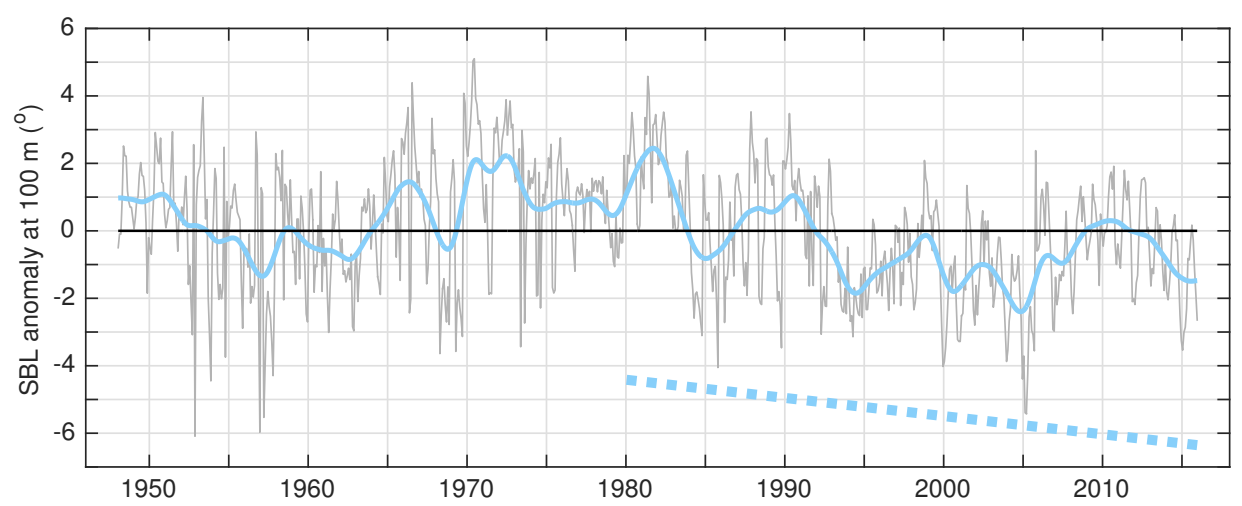

Figure 7 | Time series of the SBL anomalies at $100 \mathrm{~m}$. | Monthly means (light gray) overlaid by low-passed, 15-month multi-running means (light blue). The light blue dots indicate the linear trend for the period of $1980-2015$, which is subtracted by $5^{\circ}$ for clarity. The position used to derive the time series (100 m depth) is indicated by the light blue asterisk in Figure $6 \mathrm{~b}$.

The modulation of the low-frequency change (i.e., long-term change of the mean position of the $\mathrm{SBL}$ ) on high-frequency variability (i.e., seasonal variability of the $\mathrm{SBL}$ ) is shown in Figure 8. This figure provides a more detailed view of the SBL annual cycle and its associated long-term variability; by first characterizing the SSEC bifurcation climatological annual march from its northernmost to southernmost position (hereinafter, NP and SP) along its vertical profile extent (Fig. 8a) and the detailed surface climatology (Fig. 8b). Since ORAS4 seemed to perform better among the six reanalysis products described in Section 2.1.4, its annual cycle is displayed in $8 \mathrm{~b}$ as well, for reference; plus, the annual cycle derived from the CFSR reanalysis product is shown as a parameter to compare differences between model-reanalysis and reanalysis-reanalysis, showing that the discrepancies between CESM-OCN and ORAS4 climatological SSBL are still within an acceptable range.

The climatological SSBL moves to its SP in July (May) and to its NP in December (November) for CESM-OCN and CFSR (for ORAS4), as shown in Fig. 8b. These seasonal variations are in close agreement with the numerical model results from R2007, in which the SBL northernmost (southernmost) position occurs in November (July) in the top $400 \mathrm{~m}$ (which corresponds roughly to the ventilated thermocline and accounts for most of the seasonal variability in the bifurcation latitude, according to the authors).

In Fig. 8c, each annual value of the seasonal amplitude of the SSBL (brown line, hereinafter $\mathrm{Ab}$ ) represents the difference in latitude from the month of NP to the month of SP of the SSBL in that year, i.e., the distance between the annual values of the red and blue time series in Fig. $8 d-$ where the SSBL time series was deconstructed into time series of NP and SP in each year. The corresponding month of the respective extreme bifurcation position in $8 \mathrm{~d}$ can be seen as another time series in 8e, showing that, although climatological months of NP and SP are December and July, respectively, these extremes are revealed to occur in different periods over the years, mainly when it comes to the SPs - where fluctuations reach up to 5 months (blue line 

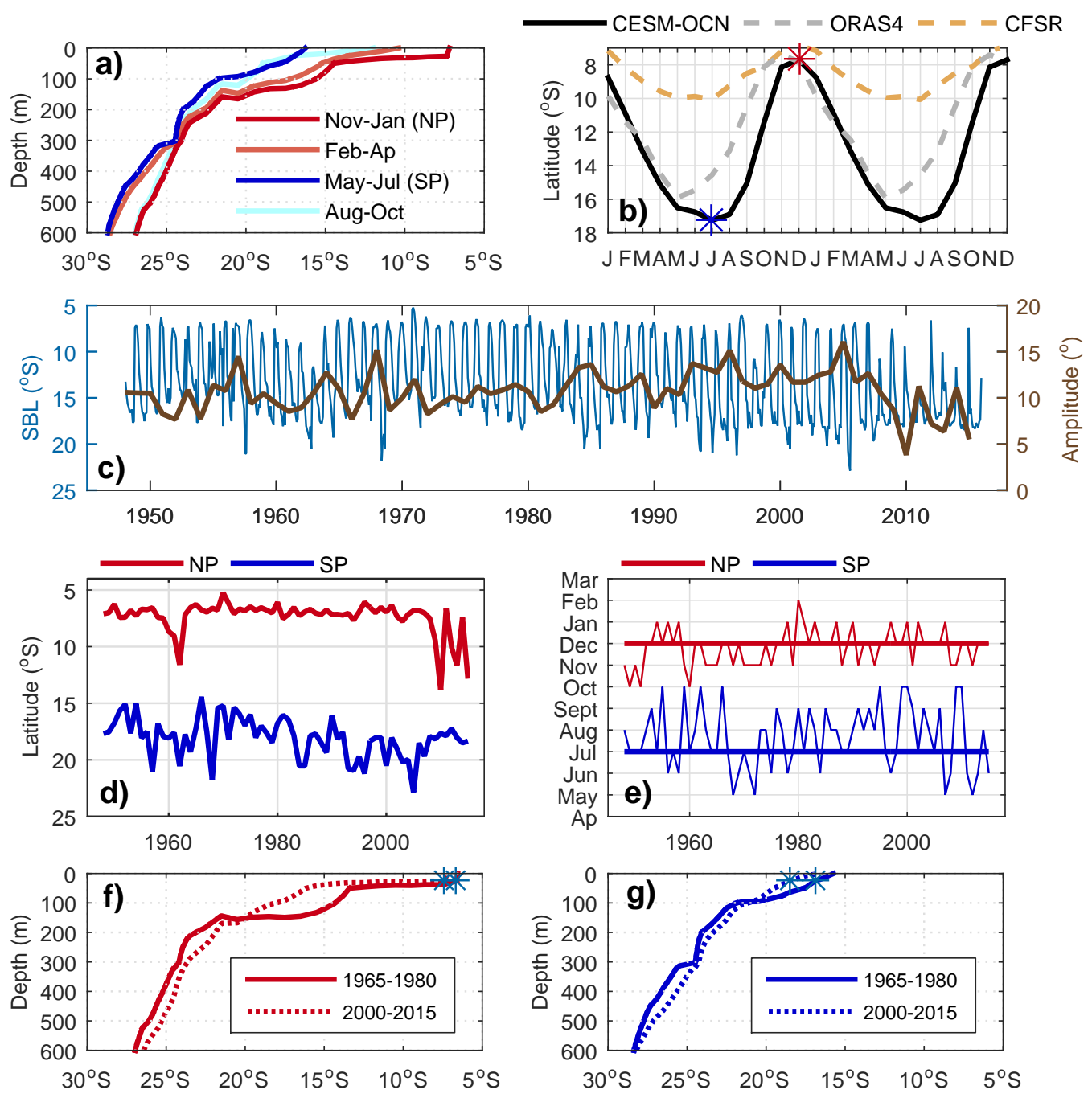

Figure 8 SBL Seasonal Variability. | (a) Full-depth (0-600 m) sSEC Bifurcation annual march, denoting the vertical profile for months of northernmost position (NP) and southernmost position (SP), as well as months in between. (b) Climatological SSBL derived from CESM-OCN (solid black, 1948-2015 base period), ORAS4 (dashed gray, 1960-2010 base period) and CFSR (dashed orange, 1960-2010 base period), where red (blue) asterisk indicates the NP (SP) for CESM-OCN. (c) Time series of the monthly SSBL (blue) and seasonal amplitude (brown). (d) SBL time series only for months of NP (red) and SP (blue) in each year. (e) Respective months of NP (red) and SP (blue) in each year. Straight lines represent the climatological months of NP and SP (December and July, respectively). (f) Difference in the sSEC bifurcation vertical profile between 1965-1980 and 2000-2015 (as in Fig. 6b), except that averaged only for the months of sSBL NP. (g) Same as 8 , but for the months of SSBL SP.

in Fig. 8e).

As to the mean seasonal south-north migration (the $A b$ ), the bifurcation latitude varies by $10.7^{\circ}$ at the surface. While, according to R2007, it shifts by $7^{\circ}$ in the top $100 \mathrm{~m}$ and by about $3^{\circ}$ from $100 \mathrm{~m}$ to $400 \mathrm{~m}$. In Fig. $8 \mathrm{c}$, where the SBL time series and its corresponding $\mathrm{Ab}$ are displayed, there is a noticeable feature in addition to the southward shift of the mean position: $A b$ increases mainly after the 70 's, by about $3.51^{\circ}$, and then falls from 2005 on. The factors controlling 
Table 3: Magnitude of the seasonal amplitude of worldwide bifurcations, in comparison to the SBL in the SAO.

\begin{tabular}{|c|c|c|}
\hline Reference & Vertical Level/Layer & $A b$ \\
\hline SAO SBL - This study & surface / top 400 m & $10.7^{\circ} / 4.2^{\circ}$ \\
\hline SAO SBL - R2007 & top $100 \mathrm{~m}$ & $7^{\circ}$ \\
\hline SIO SBL - Chen et al. (2014) & surface & $1.5^{\circ}$ \\
\hline NPO NBL - Different studies* & top $400 \mathrm{~m}$ & $1^{\circ}-2.5^{\circ}$ \\
\hline SPO SBL - Chen and Wu (2015) & surface / top $410 \mathrm{~m}$ & $3.6^{\circ} / 2.9^{\circ}$ \\
\hline
\end{tabular}

the long-term change of the Ab are beyond the scope of this work; nevertheless, R2007 suggest that the seasonal variability of the SBL in the upper thermocline is related primarily to variations in wind forcing by combined effect of local Ekman pumping and remotely forced Rossby waves.

The seasonal cycle of the SBL off the South American coast is generally analogous to that in the NPO, SPO and SIO, all of which shift synchronously back and forth seasonally and arrive at their southernmost positions in austral late autumn and early winter.

Other studies have also investigated the seasonal variation of equatorial current bifurcations in the other ocean-basins: the SEC bifurcation in the SIO and the NEC and SEC bifurcations in the NPO and SPO (e.g., Chen et al., 2014; Qiu and Lukas, 1996; Kim et al., 2004; Chen and $\mathrm{Wu}, 2011,2012,2015$, respectively), suggesting that, in the upper thermocline, they likely share the same governing dynamics, influenced by baroclinic adjustment - except maybe for the SIO, which has also the combined effect of the Madagascar island changing the western boundary topography.

The magnitude of the SBL's Ab in the SAO here described and also according to R2007 is substantially bigger than that of its other oceans' counterparts (Table 3 ).

The difference between the climatological vertical profile averaged in years of northerly and southerly bifurcation position (as shown in Fig. 6b) is further decomposed into the months of NP (Fig. 8f) and SP (Fig. 8g) of the annual cycle in those years.

Therefore, through Figure $8 \mathrm{~d}$, it is clear that the linear trend in the SSBL (shown in Fig. 6a) is led mostly by months of SP, whereas the time series of NPs presents more steadily fluctuations, with no apparent long-term changes. And this is confirmed by Figures $8 \mathrm{f}$ and $8 \mathrm{~g}$, which show that at the surface, the difference in the vertical profile is bigger for months of SP. Relative to the change in the mean position of the Pacific NBL and SBL the southward migration of the SBL in the SAO stands out, with a displacement rate twice as big (Table 4). 
Table 4: Comparison of the southward shift of the SAO SBL in this study with Pacific NBL and SBL, from Chen and Wu (2012) and Zhai et al. (2014), respectively.

\begin{tabular}{ccccc}
\hline Bifurcation & Level/Layer & Period & Shift & Rate \\
\hline SAO SBL & surface & $1948-2015$ & from $11.5^{\circ}$ to $15^{\circ} \mathrm{S}$ & $-0.051^{\circ} \mathrm{yr}^{-1}$ \\
NPO NBL & upper $381 \mathrm{~m}$ & $1950-2008$ & from $15.5^{\circ}$ to $13.9^{\circ} \mathrm{N}$ & $-0.028^{\circ} \mathrm{yr}^{-1}$ \\
SPO SBL & upper $200 \mathrm{~m}$ & $1950-2010$ & from $14.5^{\circ}$ to $15.7^{\circ} \mathrm{S}$ & $-0.020^{\circ} \mathrm{yr}^{-1}$ \\
\hline
\end{tabular}

* See Figure 4 from Hu et al. (2015) for instance, where both Pacific NBL and SBL time series from these studies are displayed.

Analogous to what was pointed out by Chen and Wu (2012) when discussing the longterm trend of the Pacific NBL, this type of southward shift in the SBL is associated with a poleward stretching of the boundary between the tropical gyre and the subtropical gyre in the upper western Atlantic Ocean, implying a substantial impact on the origin of the low-latitude WBCs near the South American coast.

Therefore, the relation between the bifurcation latitude in the upper ocean and the transport of the generated WBCs will be further explored in Section 3.4.3.

\subsection{Long-term change of SASG dynamics}

After reporting changes in the SBL, it is desirable to investigate how these observed changes relate to changes in the basin-wide gyre circulation - through analysis of the SASG dynamical fields: WSC/SVT, SSH, BSF and SST.

The wind stress is a driving agent of ocean currents, but it is the horizontal gradient rather than the absolute strength that mostly matters - the large-scale WSC, which is, in general, the major forcing mechanism of the upper ocean (Goni and Wainer, 2001; Cai, 2006). Nevertheless, changes in the local basin-scale wind-driven circulation can be plausibly inferred from changes in the SVT field (e.g., Saenko et al., 2005) - which yields a relation for wind-forced flow transport dominated by the Earth's rotation. Variations in the SSH, in turn, can provide important insights into large-scale ocean circulation, since physical processes highly impact global mean sea level. As to the BSF field, it gives exclusive information about the barotropic, "depth averaged" component of the flow, which varies solely due to horizontal variations in surface height without compensation in the ocean interior. And, finally, the SST field strongly affects ocean-atmosphere coupling and, therefore, also responds to the mean ocean circulation.

Worldwide examples:

One topic of great importance for the dynamical understanding of ocean circulation is recognizing the existing linkages among the processes involved. Several studies have explored the relation between the large-scale forcings: by investigating low-frequency circulation changes 
in the SPO through wind-forced SSH anomalies (Qiu and Chen, 2006) or even using SSH anomalies in the NPO as a proxy for the NEC bifurcation (Qiu and Chen, 2010). The latter study further relates the bifurcation of the NEC, on interannual and longer time scales, to the Niño-3.4 index, which is derived from SST data. Chen and Wu (2012) also explore ENSO-related NBL variability, in conjunction with the influence of large-scale WSC and Sverdrup dynamics. While Qiu and Chen (2012) assess multidecadal sea level and gyre circulation variability in the northwestern tropical Pacific ocean, revealing that the thermosteric sea level rise is dynamically associated with changes in the NEC transport. These are, in turn, largely attributable to upper-ocean water mass redistribution modulated by the surface wind forcing field. In the North Atlantic Ocean, the linkage between SSH and upper-ocean gyre circulation, for instance, has been explored by Wang et al. (2015); while the relationship between SST and circulation has been investigated by Delworth and Mann (2000). In the SAO, Goni et al. (2011) report observed low frequency variability in the southern limb of the subtropical gyre from satellite-derived SSH and SST observations and Pontes et al. (2016) relate projected changes in upper ocean transport to variations in the WSC field and associated poleward shift of the gyre's southern boundary.

Although the present study does not establish a specific mechanism for linking the different components of gyre circulation, it intends to reinforce the notion that potential changes in the SAO may simultaneously manifest in various of the hydrographic as well as atmospheric fields involved in the processes of ocean circulation.

In order to elucidate how these changes in the basin-scale SASG dynamics are explored in this study, Figure 9 provides a comprehensive framework of the dynamical fields integration through two complementary panels. The top panel shows superimposed zero contours for the WSC, SSH and BSF, with the WSC as background colors; while the lower panel displays superimposed contours of SVTO, WSCO and BSF0, with the SVT as background colors, that is, the zonally integrated WSC, by the Sverdrup relation. The gray (top) and white (bottom) bars refer to where climatological maximum SSH and |BSF| fields are located, respectively; and therefore, to the width taken into account to derive the latitude time series in Figure 13. As to the maximum WSC, its latitudinal position represents an average of the full domain. The SST field is considered separately, once its spatial distribution is given through linearly increasing values along the meridional extent of the basin, instead of through enclosed contours (see Section 2.2.2 for detailed explanation). 

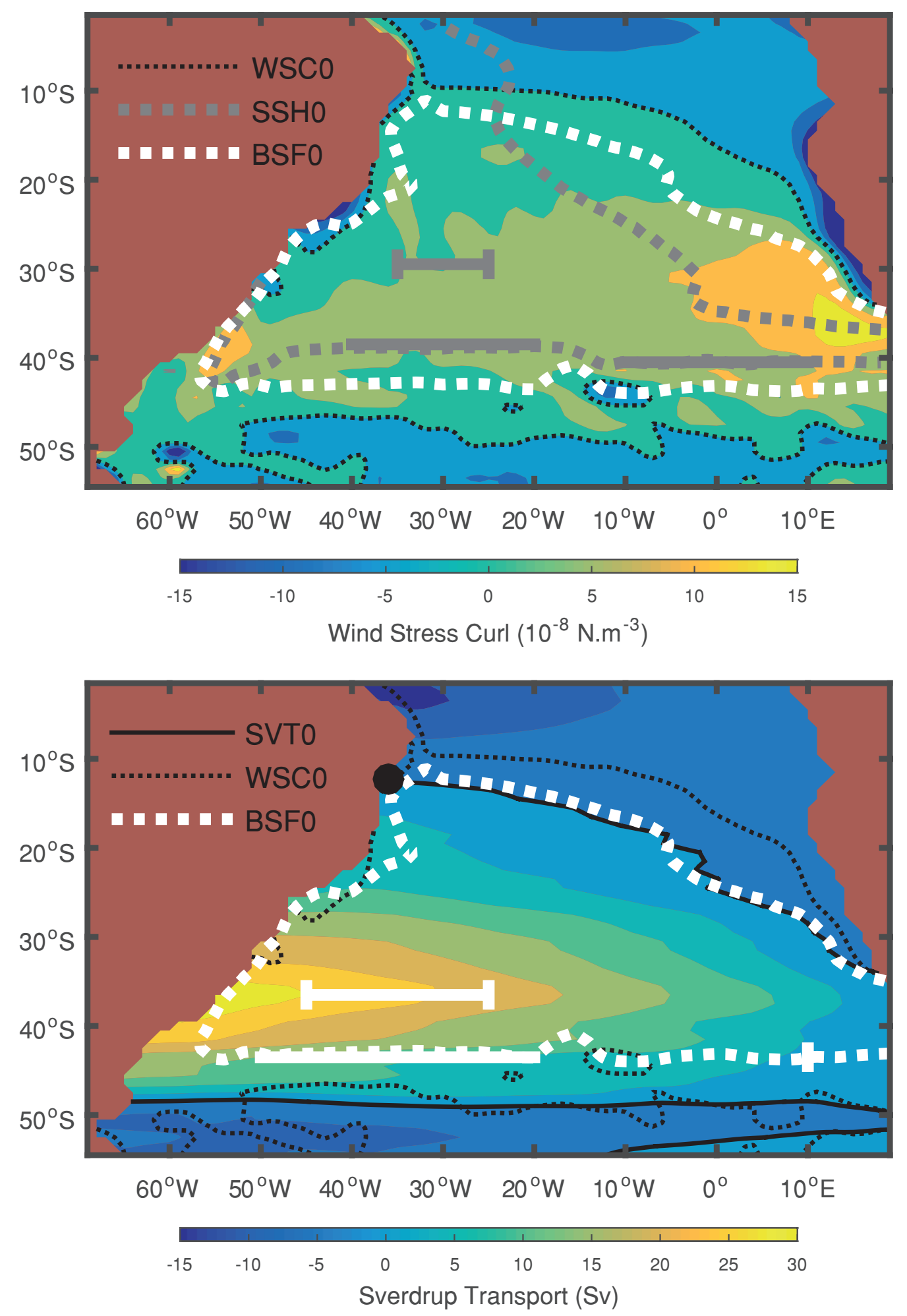

Figure 9 | Schematic of the South Atlantic basin-scale controlling dynamics. | (Top) Background colors show the mean WSC field (contour interval: $0.5 \mathrm{~N} \cdot \mathrm{m}^{-3}$ ), where positive values within the gyre are bounded by thin black dotted lines (WSCO contour). Thick gray dashed lines demarcate the contour of $\mathrm{SSH} 0$, while gray zonal labels indicate the widths used to derive the time series of the position of maximum zonally averaged SSH $\left(35^{\circ}-25^{\circ} \mathrm{W}\right.$, center) and of the $\mathrm{SSH} 0$ at a western $\left(40^{\circ}-20^{\circ} \mathrm{W}\right)$ and an eastern portion of the basin $\left(10^{\circ} \mathrm{W}-10^{\circ} \mathrm{E}\right)$. Thick white dashed lines demarcate the contour of BSF0. (Bottom) Same as top panel but with mean SVT field as background colors (contour interval: $5 \mathrm{~Sv}$ ), where positive values within the gyre are bounded by the thick solid black line. The black dot centered at $36^{\circ} \mathrm{W}$ shows the location used to derive the SVT0 time series at the northern boundary. White labels denote the widths and location used to derive the time series of the position of maximum zonally averaged $|\mathrm{BSF}|\left(45^{\circ}-25^{\circ} \mathrm{W}\right.$, center) and of the BSF0 at a western $\left(50^{\circ}-20^{\circ} \mathrm{W}\right)$ and an eastern portion of the basin $\left(10^{\circ} \mathrm{E}\right)$. 
The large-scale zero contours reveal the path of the gyre-wide circulation and the connection between the Atlantic and the Indian oceans - part of a southern midlatitude inter-basin "super-gyre" (e.g., Cai et al., 2005; Speich et al., 2007).

Among the analyzed fields, one could say that the all-embracing one is the WSC. At the northern boundary, from the inside, it is noticeable how the BSF0 follows the WSCO line, in a way that in the resulting zonal integration of the WSC, the SVTO accurately coincides with the BSFO at the entire upper limb. The SSH emerges as the innermost field, narrowly confined inside all other zero contours, except for its northwestern rim, which veers northward towards the equator (top panel of Fig. 9).

The basin-averaged differences before and after the 80's (solid versus dashed lines in Fig. 10) are more pronounced relative to the wind field, expressed by the changes in TAUX, WSC and SVT. Nevertheless, albeit comparatively modest, increasing trends can be seen in all fields.

More specifically, the easterly zonal wind stress (TAUX) north of $30^{\circ} \mathrm{S}$ intensifies, while the westerlies' magnitude substantially increases south of $40^{\circ} \mathrm{S}$, which favours the intensification and poleward displacement of the positive curl, especially at this same region. However, despite this overall intensification of the positive WSC south of $20^{\circ} \mathrm{S}$, it seems to slightly weaken between $13^{\circ}-20^{\circ} \mathrm{S}$ (Fig. 10a). The variation of the zonal mean SVT naturally reflects those of the WSC, revealing an increased northward basin interior transport implied by the positive WSC intensification, together with the analogous poleward displacement of the system (Fig. 10b). Zonally averaged $\mathrm{SSH}$, in this case regarding the western portion of the basin, rises in the constraints of the zero contour, as well as south of $40^{\circ} \mathrm{S}$, where sea level assumes negative values. This is also a suggestion of a southward displacement (Fig. 10c). Accordingly, the difference in basin-wide zonally averaged BSF shows increased barotropic transport within the gyre (negative values north of $43^{\circ} \mathrm{S}$ ) with corresponding decreased barotropic transport south of the BSF0 line, where the $S A C$ and ACC transports take place. However, this decrease can also be viewed in terms of a general poleward migration (Fig. 10d). When it comes to the surface temperature, the warming seems to be more restricted to the region closer to the equator (Fig. 10e).

In Figure 10f, the latitude of transition from negative to positive meridional velocities represents the mean SBL for the top $200 \mathrm{~m}$. As northwards (positive) velocities are clearly increasing, dashed lines (1980-2015) cross the zero VVEL line in southerly positions, compared to the solid lines (1948-1979). This is consistent with the southward displacement of the SBL, described in Section 3.2 . 
a) WSC $\left(10^{-7} \mathrm{~N} \cdot \mathrm{m}^{-3}\right)$

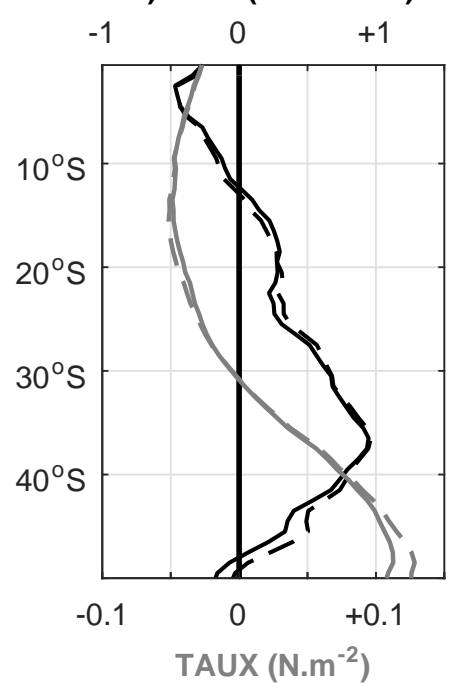

d) BSF (Sv)

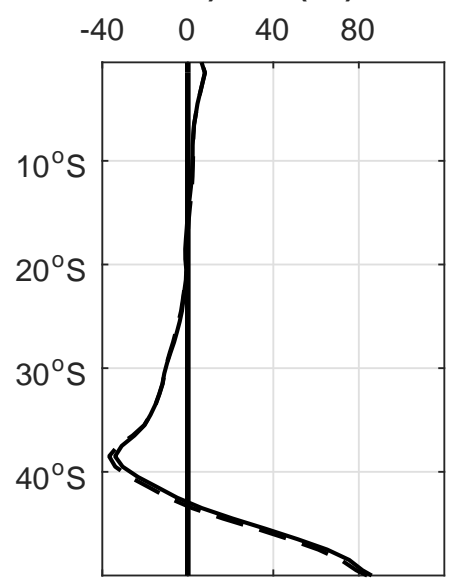

b) SVT (Sv)

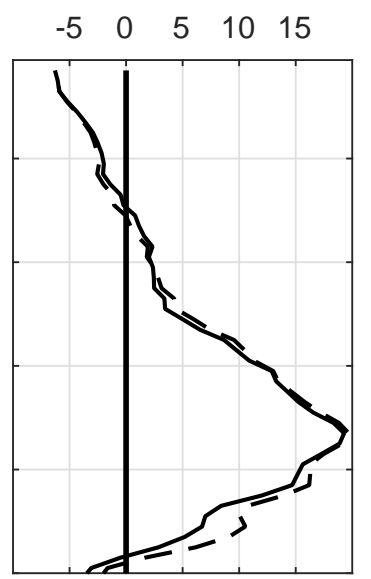

e) SST $\left({ }^{\circ} \mathrm{C}\right)$

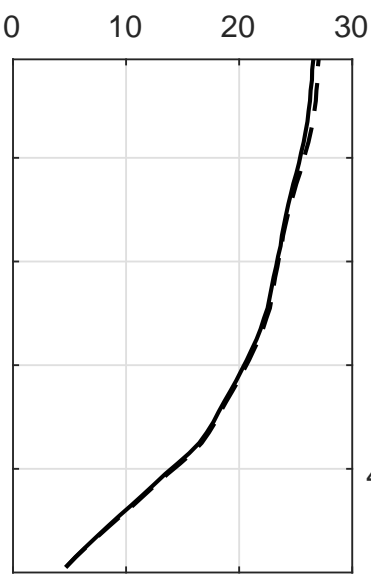

c) $\mathrm{SSH}(\mathrm{cm})$

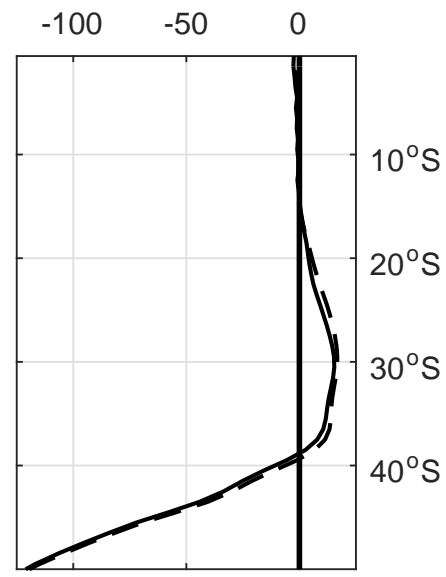

f) $\operatorname{VVEL}^{*}\left(m \cdot s^{-1}\right)$

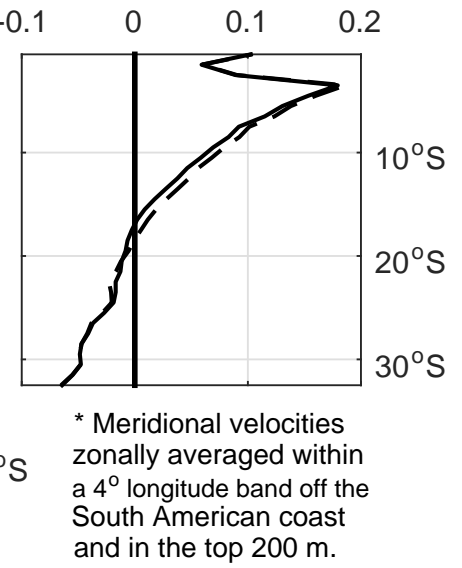

Figure 10 | Transition of South Atlantic zonally averaged fields. | (a) Wind Stress Curl (black curve) and Zonal Wind Stress (TAUX, gray curve); (b) Sverdrup Transport; (c) Sea Surface Height, from the western boundary up to $10^{\circ} \mathrm{W}$ (recall Fig. 2b); (d) Barotropic Stream Function; (e) Sea Surface Temperature; and (f) Meridional Velocity, from the South American coast (i.e., the western boundary) up to $4^{\circ}$ longitude eastwards. The velocities are also vertically averaged within the top $200 \mathrm{~m}$ layer. Solid (dashed) lines represent the period ranging 1948-1979 (1980-2015). The WSC, TAUX, SVT, BSF and SST are zonally averaged along the entire basin.

When addressing the "core structure" of the gyre, the anomalies of positive (negative) WSC and SSH (BSF) within the zero and the further confined contours of $5 \times 10^{-8} \mathrm{~N} \cdot \mathrm{m}^{-3}$ and 15 $\mathrm{cm}(-10 \mathrm{~Sv}$ ) all show a substantial increase (Figure 11), displaying statistically significant positive linear trends after the 80's (Table 5). 

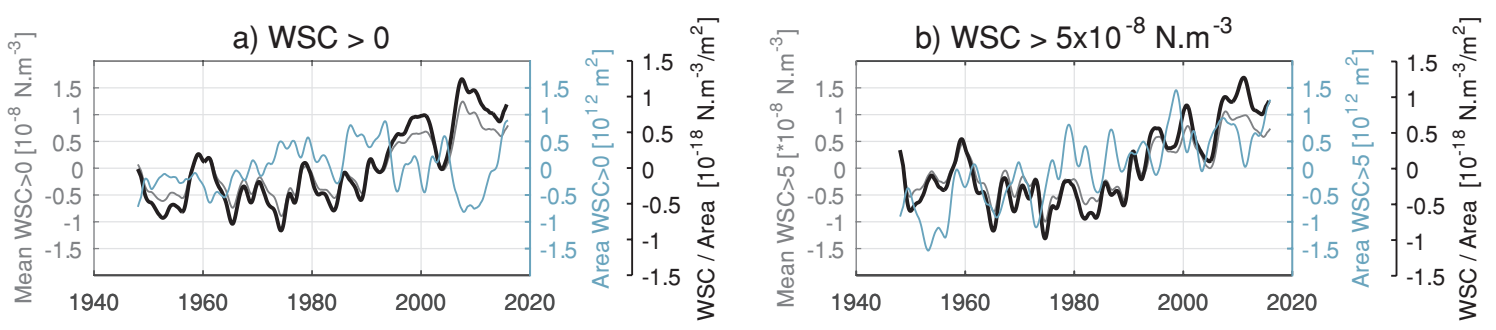

c) $\mathrm{SSH}>0$

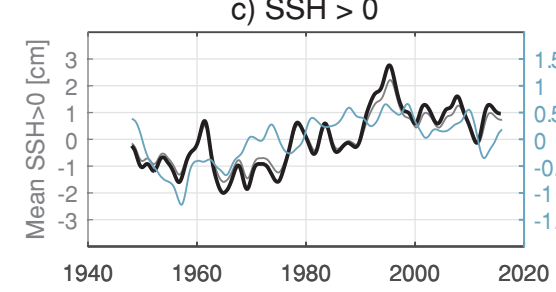

e) $\mathrm{BSF}<0$

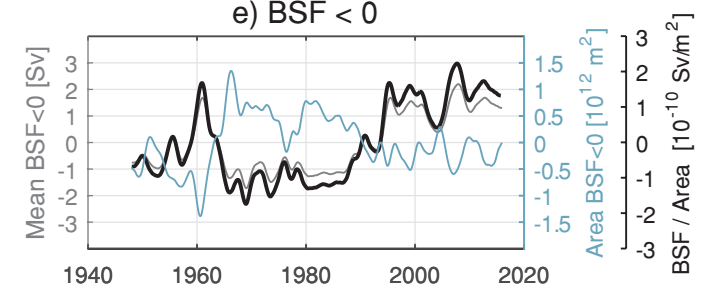

d) $\mathrm{SSH}>15 \mathrm{~cm}$
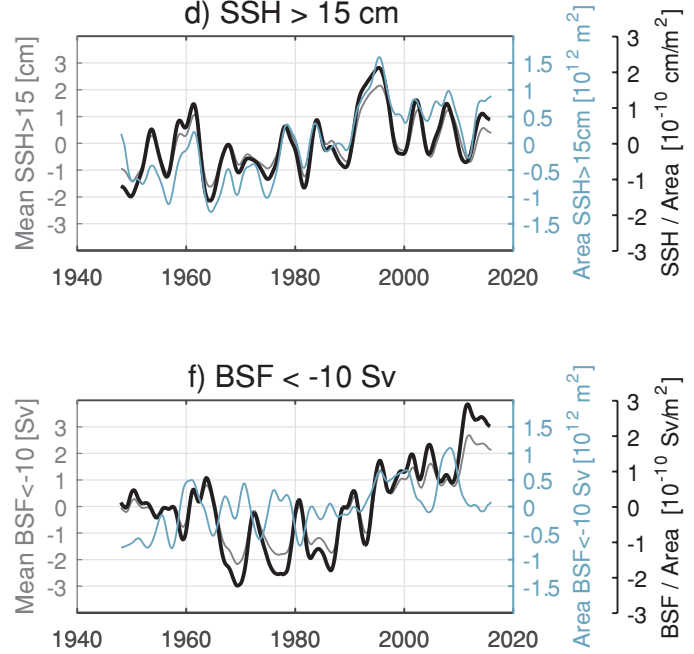

Figure 11 | Low frequency SASG variability. | Low-passed anomalies of mean (a) WSC, (c) SSH and (e) BSF horizontally averaged inside their zero contour within the SASG (gray); of the corresponding area enclosed by the respective zero contour (light blue) and resulting time series of mean WSC/SSH/BSF per area (i.e., the gray divided by the blue line - in thick black lines). (b) (d) (f) Same as (a)/(c)/(e) but averaged inside the (b) $5 \times 10^{-8} \mathrm{~N} \cdot \mathrm{m}^{-3}$ WSC line, (d) $15 \mathrm{~cm} \mathrm{SSH}$ line, and (f) -10 Sv BSF line (recall Figure 2 from Section 2.2.2 for reference, where these specific contours are shown).

Table 5: Total period mean value and increase corresponding to the 1980-2015 period of the time series of mean WSC, SSH and BSF within contours (displayed as gray lines in Figure 11). The mean values refer to the corresponding raw time series (since the anomalies in Fig. 11 are with respect to their annual cycles).

\begin{tabular}{lcc}
\hline Time series & Mean value & 1980-2015 increase \\
\hline a) $\mathrm{WSC}>0$ & $7.6 \times 10^{-8} \mathrm{~N} \cdot \mathrm{m}^{-3}$ & $1.5 \times 10^{-8} \mathrm{~N} \cdot \mathrm{m}^{-3}$ \\
b) $\mathrm{WSC}>5 \times 10^{-8} \mathrm{~N} \cdot \mathrm{m}^{-3}$ & $10.6 \times 10^{-8} \mathrm{~N} \cdot \mathrm{m}^{-3}$ & $1.6 \times 10^{-8} \mathrm{~N} \cdot \mathrm{m}^{-3}$ \\
c) $\mathrm{SSH}>0$ & $10.7 \mathrm{~cm}$ & $0.8 \mathrm{~cm}$ \\
d) $\mathrm{SSH}>15 \mathrm{~cm}$ & $18.1 \mathrm{~cm}$ & $0.3 \mathrm{~cm}$ \\
e) $\mathrm{BSF}<0$ & $-15.3 \mathrm{~Sv}$ & $|-3.3| \mathrm{Sv}$ \\
f) $\mathrm{BSF}<-10 \mathrm{~Sv}$ & $-25.2 \mathrm{~Sv}$ & $|-3.7| \mathrm{Sv}$ \\
\hline
\end{tabular}

${ }^{*}$ All linear trends corresponding to the $1980-2015$ period are statistically significant at the $95 \%$ confidence level. 
The black solid time series in Fig. 11 represent: the mean fields within the indicated contours (in gray lines), taking into account the respective areas enclosed by these contours as well (in light blue lines), at each time step. WSC and BSF (SSH) strength hold an indirect (direct) relation with their filling areas (with correlation coefficients reaching up to -0.66 for the WSC in Fig. $11 \mathrm{a},+0.83$ for the SSH in Fig. $11 \mathrm{~d}$ and -0.82 for the BSF in Fig. 11e). However, the resulting time series "Mean intensity per Area" is not substantially affected by this and does not change our conclusions that the WSC, SSH and BSF strength are indeed increasing. For this same reason, the 1980-2015 linear trend values presented in Table 5 are relative to the gray time series in Fig. 11 (instead of the black ones), as this highlights the idea of how much of each field is really strengthening.

Figure 11 is summarized by Figure 12, which expresses reasonably well the transition from the late 20th into the early 21st century: with increasing values of WSC, SSH and BSF within the SASG domain, obtained from within the respective zero contours which delimitate the governing dynamics of the subtropical gyre circulation (i.e., positive WSC, positive SSH and negative BSF).
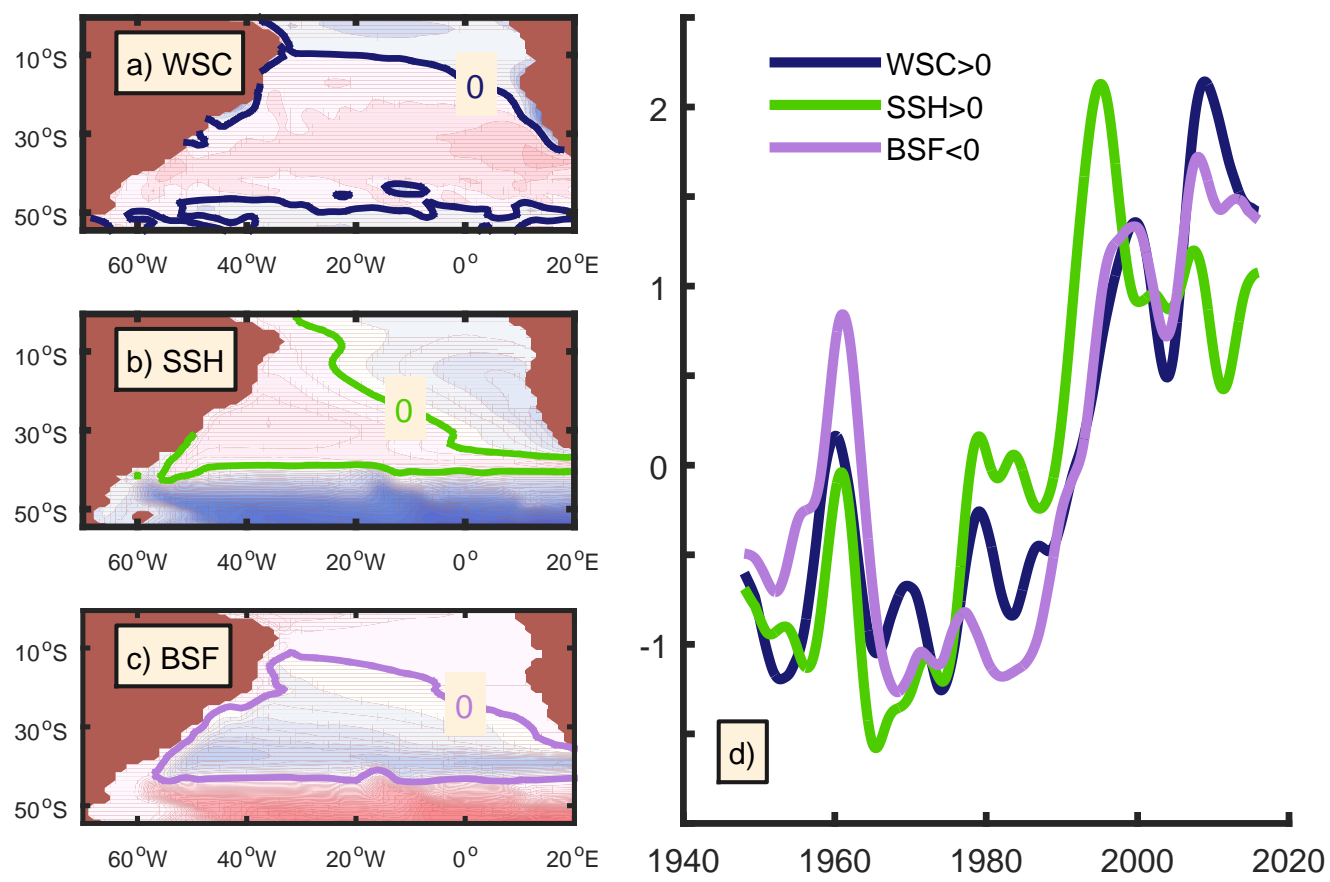

Figure 12 | Highlights of the 21st century intensification of SASG circulation. | Climatological mean (a) WSC, (b) SSH and (c) BSF fields with their respective zero contours indicated for reference. (d) Low-passed (35-month multi-running mean), normalized (by standard deviation) anomalies of mean WSC (dark blue), SSH (green) and BSF (lilac) per area, within the zero contours (same time series as in Figure 11a, c, e; save for the differentiated statistical treatment).

Time series of the maximum WSC, SSH and $|\mathrm{BSF}|$ and of their respective latitudes are displayed in Figure 13. The maximum values show an overall increase, especially after the 80 's, whilst their respective latitudes concurrently migrate southwards. The maximum SSH (13c) 
seems to linearly increase from 1948 to 2015 , whereas maximum WSC (13a) and |BSF| (13e) do not increase continuously - in addition to the total period linear trend, they both decrease from 1948-1979 after which they show an increasing trend, from 1980 to 2015. All the linear trends in Figure 13 are detailed in Table 6.

a) Maximum WSC

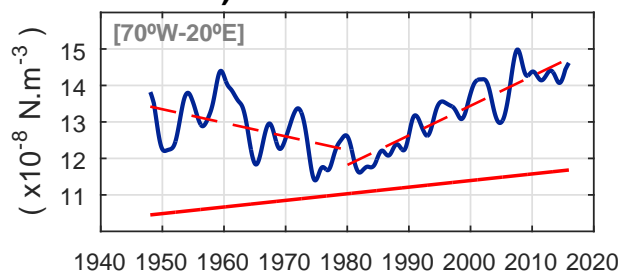

c) Maximum SSH

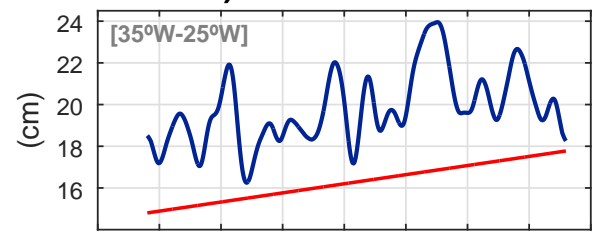

194019501960197019801990200020102020

e) Maximum |BSF|

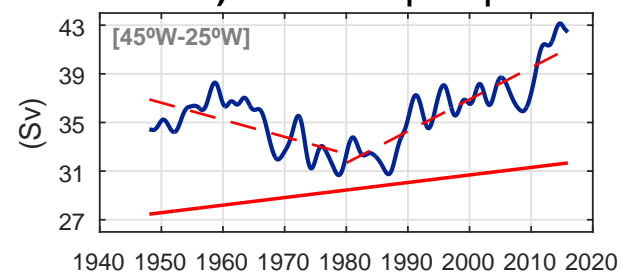

b) Latitude of Max. WSC

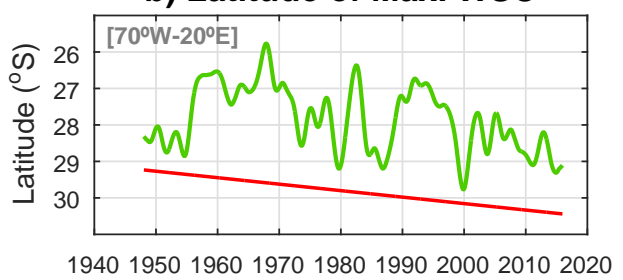

d) Latitude of Max. SSH

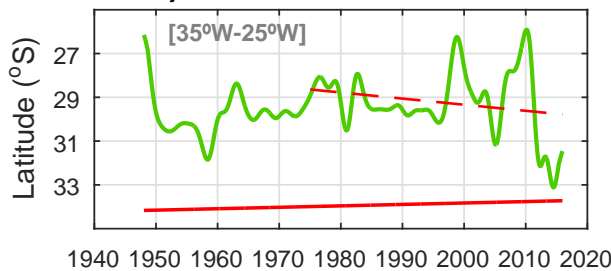

f) Latitude of Max. |BSF|

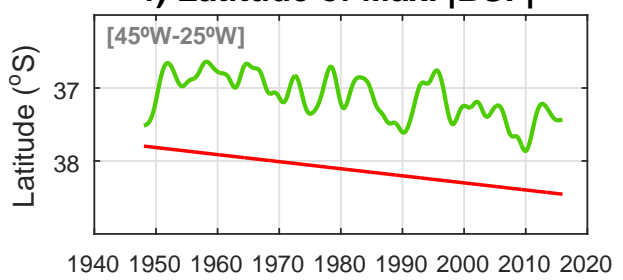

Figure 13 | Intensity and latitude of maximum zonally averaged fields. | Low-passed time series of (a) maximum WSC and (b) respective latitude of maximum WSC, averaged over $70^{\circ} \mathrm{W}$ $20^{\circ} \mathrm{E}$; (c) maximum SSH and (d) respective latitude of maximum SSH, averaged over $35^{\circ}-25^{\circ} \mathrm{W}$; (e) maximum $|\mathrm{BSF}|$ and (f) respective latitude of maximum $|\mathrm{BSF}|$, averaged over $45^{\circ}-25^{\circ} \mathrm{W}$. The zonal bands used for averaging the SSH and BSF are displayed as gray and white labels in Fig. 9. Total linear trends (1948-2015, red solid lines) are subtracted by: (a) $2 \times 10^{-8} \mathrm{~N} \cdot \mathrm{m}^{-3}$, (b) $2^{\circ}$, (c) $3.5 \mathrm{~cm}$, (d) $4.5^{\circ}$, (e) $6 \mathrm{~Sv}$ and (f) $1^{\circ}$, for clarity. Dashed red lines denote linear trends for separate periods: (a, e) 1948-1979 / 1980-2015; (d) 1975-2015. All the linear trends displayed (both total and separated periods) are statistically significant at the $95 \%$ confidence level. 
Table 6: Linear trends from the time series in Fig. 13. The separate period ranging 1948-1979 (1975/1980-2015) is marked in brown (red), for reference.

\begin{tabular}{lcc}
\hline \multicolumn{1}{c}{ Time series } & Period & Linear trend \\
\hline a) Max. WSC & $1948-2015$ & $+1.23 \times 10^{-8} \mathrm{~N} \cdot \mathrm{m}^{-3}$ \\
a) Max. WSC & $1948-1979$ & $-1.19 \times 10^{-8} \mathrm{~N} \cdot \mathrm{m}^{-3}$ \\
a) Max. WSC & $1980-2015$ & $+2.92 \times 10^{-8} \mathrm{~N} \cdot \mathrm{m}^{-3}$ \\
b) Lat. of Max. WSC & $1948-2015$ & $-1.21^{\circ}$ \\
c) Max. SSH & $1948-2015$ & $+2.97 \mathrm{~cm}$ \\
d) Lat. of Max. SSH & $1948-2015$ & $+0.44^{\circ}$ \\
d) Lat. of Max. SSH & $1975-2015$ & $-1.14^{\circ}$ \\
e) Max. $|\mathrm{BSF}|$ & $1948-2015$ & $+4.21 \mathrm{~Sv}$ \\
e) Max. $|\mathrm{BSF}|$ & $1948-1979$ & $-4.47 \mathrm{~Sv}$ \\
e) Max. $|\mathrm{BSF}|$ & $1980-2015$ & $+9.39 \mathrm{~Sv}$ \\
f) Lat. of Max. $|\mathrm{BSF}|$ & $1948-2015$ & $-0.66^{\circ}$ \\
\hline
\end{tabular}

The latitude of the maximum WSC and $|\mathrm{BSF}|$ (13b and 13f) appear to continuously migrate southward. The latitude of maximum SSH (13d) shifts to the south from 1975-2015, still, the linear trend for the entire period is positive. This positive trend of the maximum SSH position can be understood in terms of the formation of a new local of maximum, centered at approximately $28^{\circ} \mathrm{S}, 35^{\circ} \mathrm{W}$ (Figure 14b). This suggests that in addition to the southward migration of the SSH contours, increasing values are taking place in the gyre's core, which are causing the latitude of the maximum zonally averaged SSH to remain in a northerly position. 
a) SVT

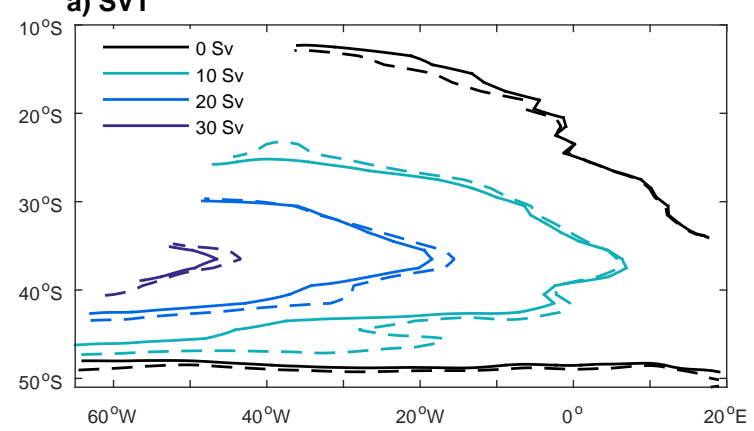

b) $\mathrm{SSH}$

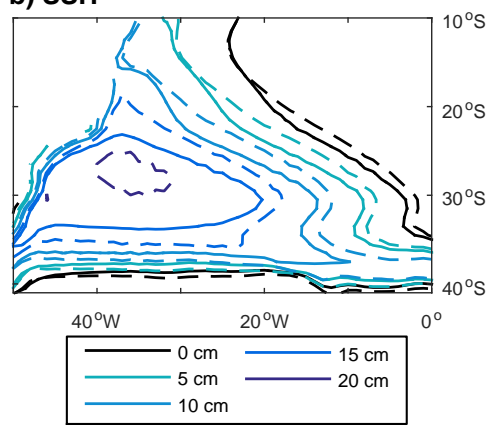

d) SST

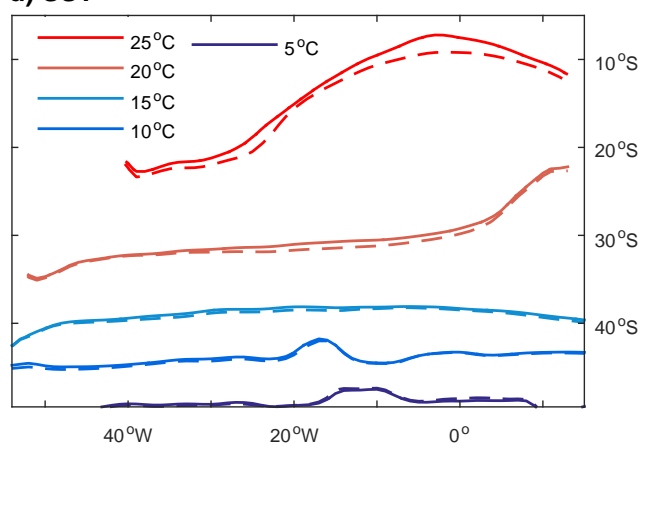

Figure 14 | Featuring the SASG poleward displacement and core intensification. | Climatological contours for the periods: 1948-1979 (solid lines) and 1980-2015 (dashed lines). Shown are the: (a) SVT, (b) SSH, (c) BSF and (d) SST fields.

A robust, recurring change pattern displayed in Figure 14 is the SASG poleward displacement (depicted by the southward shift of isopleths), combined with a core intensification, manifested through the enlargement of the regions of higher values in the center of each dynamical field (not considering the SST field).

To better explore the poleward displacement of the SASG system, time series of the dynamical boundaries were derived in regions of high gradients. Defined by the zero contours, they are: the northern edge of the positive SVT field (SVTOn), the southern edge of positive SSH field in two portions along the basin (SSHOs; $40^{\circ}-20^{\circ} \mathrm{W}$ and $10^{\circ} \mathrm{W}-10^{\circ} \mathrm{E}$ ) and the southern edge of negative BSF field in two portions along the basin as well (BSF0; $50^{\circ}-20^{\circ} \mathrm{W}$ and $10^{\circ} \mathrm{E}$ ). The spatial pattern of the SST field was monitored by time series of the isotherms of $25^{\circ} \mathrm{C}$ (at $30^{\circ} \mathrm{W}$ ) and $20^{\circ} \mathrm{C}, 15^{\circ} \mathrm{C}$ and $10^{\circ} \mathrm{C}$ (both at $30^{\circ} \mathrm{W}$ and $0^{\circ}$ longitude) (Figure 15). 
a) SVTOn

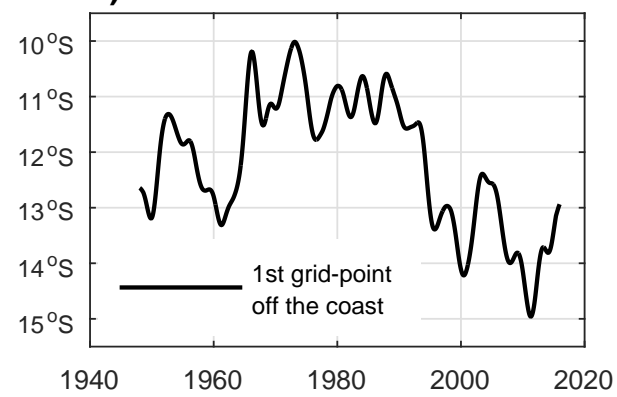

b) SSHOS

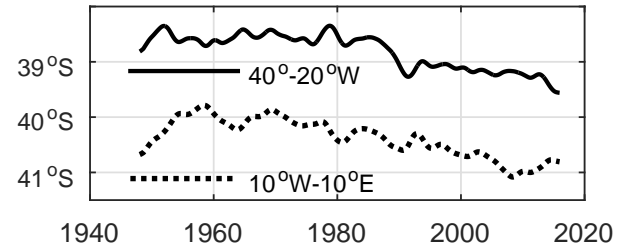

c) BSF0s

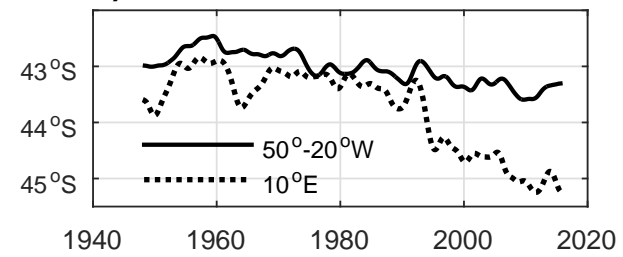

d) SST25-10

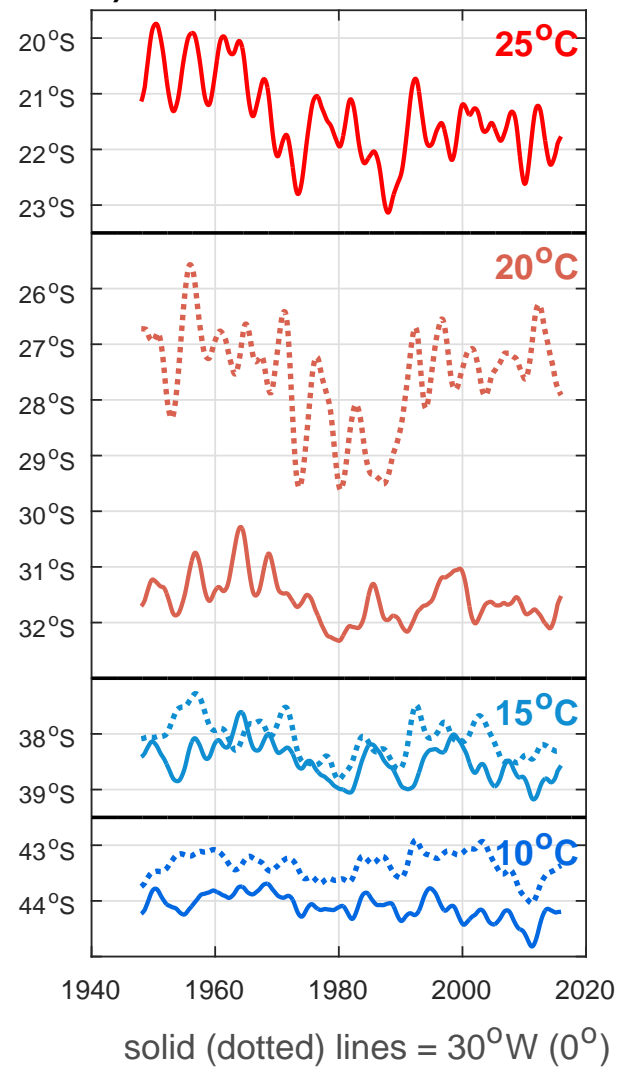

Figure 15 | Monitoring the position of SASG dynamical boundaries. | Low-pass-filtered time series of the latitude of zero contour indices derived from regions of high gradient: (a) Latitude of the SVT0 at the northern edge (SVTOn) in the $1^{\text {st }}$ grid point off the South American coast, i.e., the position of zero zonally integrated WSC line; (b) Latitude of the SSHO at the southern edge (SSHOs) in two portions along the basin: a western band ranging $40^{\circ}-20^{\circ} \mathrm{W}$ (solid line) and an eastern one, $10^{\circ} \mathrm{W}-10^{\circ} \mathrm{E}$ (dashed line); (c) Latitude of the BSF0 at the southern edge (BSF0s) in two portions along the basin as well: a western band ranging $50^{\circ}-20^{\circ} \mathrm{W}$ (solid line) and an eastern section at $10^{\circ} \mathrm{E}$ (dashed line). (d) Latitude of SST contours in two portions along the basin - the $25^{\circ} \mathrm{C}$ isotherm at $30^{\circ} \mathrm{W}$ (red solid line) and the $20^{\circ} \mathrm{C}, 15^{\circ} \mathrm{C}$ and $10^{\circ} \mathrm{C}$ (in light red, light blue and blue solid lines, respectively) isotherms at $30^{\circ} \mathrm{W}$ and $0^{\circ}$ longitude (in solid and dashed lines, respectively).

The SVTOn, SSHOs and BSFOs indices in Figure 15 all reflect a southward migration, which is more prominent especially after the 70's (except for the BSF0 at the western portion $50^{\circ}-20^{\circ} \mathrm{W}$ - whose $1948-2015$ total linear trend is bigger). The overall linear trends are statistically significant at the $95 \%$ confidence level. Table 7 lists the southward shifts corresponding to them.

The SVTOn index migrates southward from $11.21^{\circ} \mathrm{S}$ to $13.13^{\circ} \mathrm{S}$, at a rate of $0.028^{\circ} \mathrm{S}$ $\mathrm{yr}^{-1}$, considering the total period. Therefore, from $1970-2015$, the rate increases to $-0.059^{\circ} \mathrm{S}$ $\mathrm{yr}^{-1}$, reaching the latitude of $14.23^{\circ} \mathrm{S}$. This rate of southward migration is comparable to that of

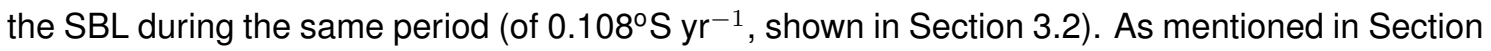
3.1, on longer time scales it is expected that the SBL coincides with the SVT0, being subject to the governing Sverdrup dynamics. Here we demonstrate that the long-term change of the low-passed 
Table 7: Total shift depicted by different periods in the time series from Figure 15. Shown are only the shifts corresponding to statistically significant linear trends, at the $95 \%$ confidence level. The 1970-2015 separate period is marked in red, for reference.

\begin{tabular}{lccc}
\hline \multicolumn{1}{c}{ Time series } & Period & Total shift & Rate $\left(\mathbf{y r}^{-1}\right)$ \\
\hline a) SVTOn & $1948-2015$ & $-1.92^{\circ}$ & $-0.028^{\circ}$ \\
a) SVTOn & $1970-2015$ & $-4.03^{\circ}$ & $-0.059^{\circ}$ \\
b) SSH0S $\left(40^{\circ}-20^{\circ} \mathrm{W}\right)$ & $1948-2015$ & $-0.94^{\circ}$ & $-0.014^{\circ}$ \\
b) SSH0s $\left(40^{\circ}-20^{\circ} \mathrm{W}\right)$ & $1970-2015$ & $-1.00^{\circ}$ & $-0.015^{\circ}$ \\
b) SSH0s $\left(10^{\circ} \mathrm{W}-10^{\circ} \mathrm{E}\right)$ & $1948-2015$ & $-0.97^{\circ}$ & $-0.014^{\circ}$ \\
b) SSH0s $\left(10^{\circ} \mathrm{W}-10^{\circ} \mathrm{E}\right)$ & $1970-2015$ & $-0.99^{\circ}$ & $-0.015^{\circ}$ \\
c) BSF0s $\left(50^{\circ}-20^{\circ} \mathrm{W}\right)$ & $1948-2015$ & $-0.83^{\circ}$ & $-0.012^{\circ}$ \\
c) BSF0S $\left(50^{\circ}-20^{\circ} \mathrm{W}\right)$ & $1970-2015$ & $-0.63^{\circ}$ & $-0.010^{\circ}$ \\
c) BSF0s $\left(10^{\circ} \mathrm{E}\right)$ & $1948-2015$ & $-2.10^{\circ}$ & $-0.031^{\circ}$ \\
c) BSF0S $\left(10^{\circ} \mathrm{E}\right)$ & $1970-2015$ & $-2.49^{\circ}$ & $-0.037^{\circ}$ \\
d) SST10 $\mathrm{C}\left(30^{\circ} \mathrm{W}\right)$ & $1948-2015$ & $-0.48^{\circ}$ & $-0.007^{\circ}$ \\
d) SST10 $\mathrm{C}\left(30^{\circ} \mathrm{W}\right)$ & $1970-2015$ & $-2.49^{\circ}$ & $-0.037^{\circ}$ \\
\hline
\end{tabular}

$\mathrm{SBL}$ is consistent with the migration of the latitude of zero WSC line integrated from east to west over the South Atlantic basin.

In the case of SSHOS, the contour is migrating southwards at the same rate $\left(-0.014^{\circ} \mathrm{S}\right.$ $\left.\mathrm{yr}^{-1}\right)$ at the western $\left(40^{\circ}-20^{\circ} \mathrm{W}\right.$, solid line $)$ and at the eastern $\left(10^{\circ} \mathrm{W}-10^{\circ} \mathrm{E}\right.$, dashed line) portions of the basin. On the other hand, the contour of BSFOs interestingly migrates at a much bigger rate $\left(-0.031^{\circ} \mathrm{S} \mathrm{yr}^{-1}\right)$ at the eastern portion of the basin $\left(10^{\circ} \mathrm{E}\right)$ than at the western $\left(-0.012^{\circ} \mathrm{S} \mathrm{yr}^{-1}\right.$, along $\left.50^{\circ}-20^{\circ} \mathrm{W}\right)$.

Curiously, however, the isotherms do not seem to follow the same variation as these other indices, expressing a different behaviour: most contours appear to undergo a "drifting disruption" before and after the $80^{\prime}$ 's, besides pronounced multidecadal variability. Only in the $10^{\circ} \mathrm{C}$ isotherm, at $30^{\circ} \mathrm{W}$, a continuous southward migration can be identified from the 70 's, later on. 


\subsection{Long-term change of SAO currents transport}

Followed by the investigation of changes in the SSBL and in SASG dynamics, it seems now suitable to explore changes in the transport of the ocean currents. Primarily the SASG northern and western limbs (the SSEC and the BC, respectively) plus the low-latitude, equatorward WBC formed after the SSEC bifurcation (the NBUC).

Thus, total velocity transports as well as the barotropic transports are assessed for the bifurcating SSEC and generated NBUC and BC; while only the barotropic transports are assessed for the SAC and the MC, since these currents consist of "secondary members" (relative to our focus) embedded in this basin-wide circulation which can shed some light to our interpretation in terms of interconnected large-scale dynamics.

\subsubsection{Total Transports}

The mean flow field is separated into meridional (Fig. 16a) and zonal (Fig. 16b) velocities. Figure 16, as a whole, suggests the idea of the SEC flow diffusely coming across the South Atlantic basin and then spreading around the South American coast, upon advancing westwards towards its northern and southern extents (the NBUC and the BC, respectively). On the map of zonal velocities (16b), both of these flows appear as negative velocities, which are progressing upstream to the north or south; yet, both directed to the west, owning to the alignment of the coast. Only the initial portion of the NBUC is directed eastward. In the left panel (16a), north and south of the mean SBL (yellow dot), these meridional flows can then be more clearly identified as western boundary currents outlining the coast. The contour of $|0.02| \mathrm{m} \mathrm{s}^{-1}$ is marked as reference in dashed lines, for both the meridional and zonal velocities, and both for the horizontal picture (longitude-latitude domain, Figure 16) as well as for the vertical profiles (longitude/latitude-depth domain, Figures 17, 18 and 19).

Hereafter, we ascribe the overall westward flow of the subtropical gyre circulation as SSEC, which is the branch that is known to form the northern limit of the subtropical gyre and to bifurcate into the NBUC and BC. The general westward flow of the SEC includes a part that turns northward near $30^{\circ} \mathrm{W}$ (Stramma, 1991), to form the South Equatorial Countercurrent (SECC), which merges into the complex equatorial current system, eventually giving rise to the northern (nSEC), equatorial (eSEC) and central (CSEC) branches, as well as the South Equatorial Undercurrent (SEUC). This flow configuration can be visualized in detail in Figure 2 from Stramma and England (1999).

Even though Stramma (1991) defines the SSEC as the flow between $10^{\circ} \mathrm{S}$ and $25^{\circ} \mathrm{S}$ and R2007 use the $6^{\circ}-22^{\circ} \mathrm{S}$ band, the use of different ranges of latitude to derive the westward transport yields just negligible differences with respect to the magnitude of the transport; the variability of the time series is not affected. Here, we adopt the band of $6^{\circ}-22^{\circ} S$, as in R2007. The sSEC can be understood as an $\mathrm{BeC}$ extension which includes both the $\mathrm{MOC}$ and the return flow of the subtropical gyre (Richardson, 2007). 
It is worth mentioning that the northward flow along the Brazil coast between $5^{\circ}$ and $10^{\circ} \mathrm{S}$ occurs as an undercurrent (the NBUC), whereas near-surface currents are weak or even southward; only near $5^{\circ} \mathrm{S}$, when it gains an easterly inflow contribution, the NBUC loses its undercurrent character and is then called the NBC (Schott et al., 1998).

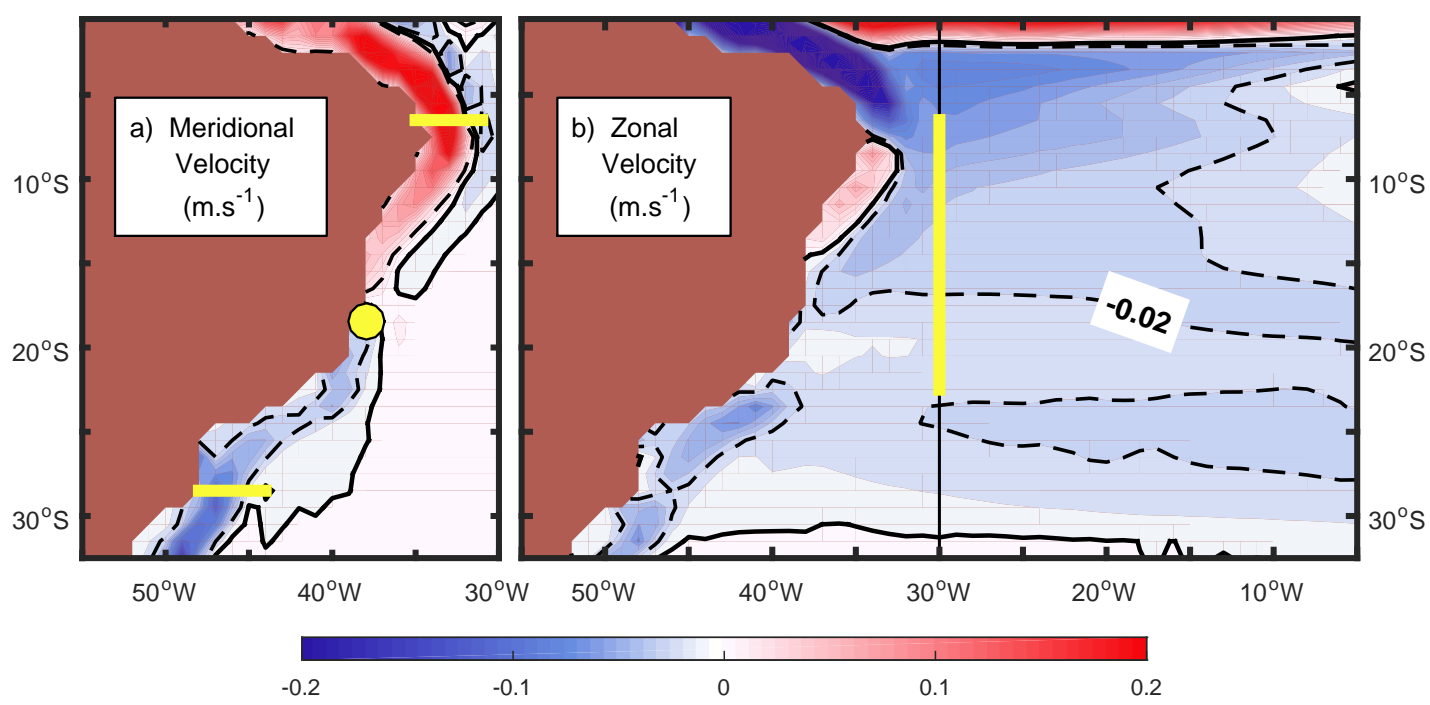

Figure 16 | Climatological flow field (1948-2015). | Depth integrated horizontal velocities in which positive velocities (northward, eastward) are in red, while negative velocities (southward, westward) are in blue. The zero-velocity line is marked in black-bold and the $|0.02| \mathrm{m} . \mathrm{s}^{-1}$ contour, used for reference, is marked by the black-dashed lines. The vertical black line along $30^{\circ} \mathrm{W}$ at the right panel (b) indicates whereupon the spatial domain transcends that of the left panel (a). (a) 0-200 m mean meridional velocities. Positive (negative) values denote northward (southward) flow. Yellow dot centered at $19^{\circ} \mathrm{S}$ represents the $0-200 \mathrm{~m}$ mean SBL $\left(<4^{\circ}\right.$ longitude off the coast) and solid yellow lines at $6.5^{\circ} \mathrm{S}$ from $35^{\circ}-32^{\circ} \mathrm{W}$ and at $28.5^{\circ} \mathrm{S}$ from $48^{\circ}-44^{\circ} \mathrm{W}$ represent transects for the calculation of NBUC and BC transports, respectively. (b) 0-200 m mean zonal velocities. Negative (positive) values denote westward (eastward) flow. Solid yellow line at $30^{\circ} \mathrm{W}$ from $6^{\circ}$ $22^{\circ} S$ represent the transect for the calculation of the SSEC transport.

As described in Stramma (1991), the SASG has its northernmost current band as the westward flowing SSEC which is found to be a broad sluggish flow, fed by the BeC. Upon approaching the western boundary and splitting into two branches, a small part of the water turns poleward to form the BC, whereas the bulk of the flow contributes to the NBUC. The results here presented confirm this described flow pattern - yielding vigorous SSEC and NBUC, contrasting with a weak and more steady BC (Figures 17, 19 and 18, respectively, with transect locations indicated in Figure 16). 
a) $30^{\circ} \mathrm{W}$

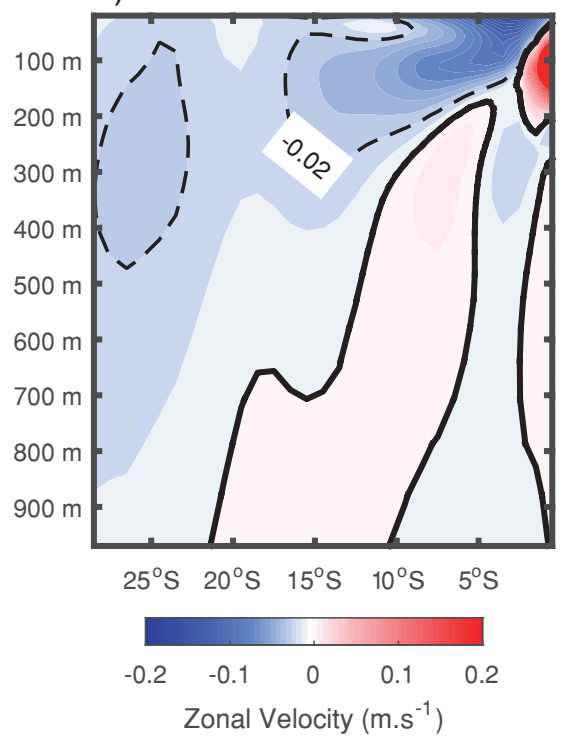

b)

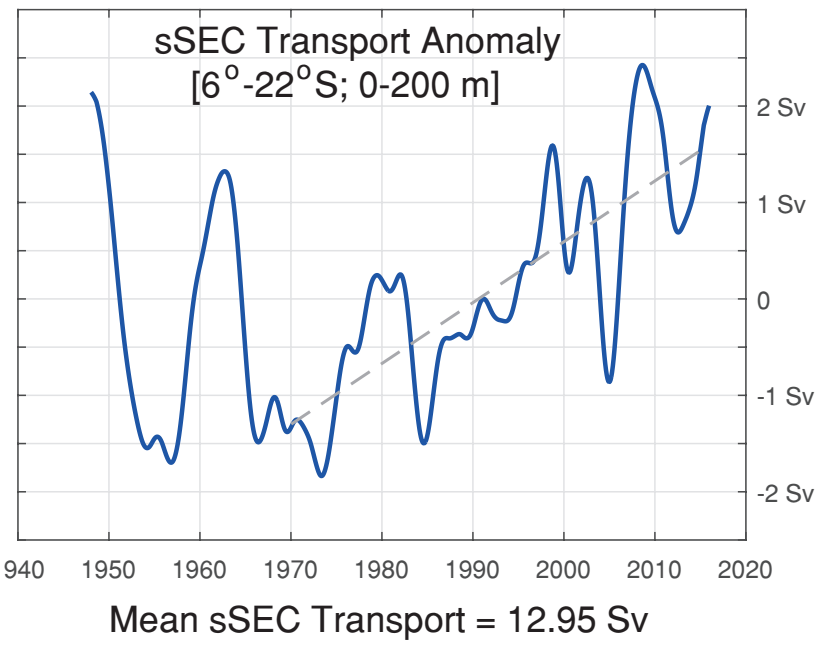

Figure 17 | SSEC vertical profile characterization and transport time series. | (a) SSEC mean vertical profile across $30^{\circ} \mathrm{W}$ represented by the 1948-2015 average zonal velocity field along $0^{\circ}$ $30^{\circ} \mathrm{S}$ latitude and up to $980 \mathrm{~m}$ depth. The westward flow is indicated by the negative values in blue. The eastward core (positive values, in red) centered in the equator above $200 \mathrm{~m}$ represents the SECC. The zero-velocity line is marked in bold and the $|0.02| \mathrm{m} . \mathrm{s}^{-1}$ contour used for reference as in Fig. 16 is indicated by the dashed lines. (b) Low-passed time series of the respective westward transport fluctuations at $30^{\circ} \mathrm{W}$ (along $6^{\circ}-22^{\circ} \mathrm{S}$ and above $200 \mathrm{~m}$ ) about its mean volume of 12.95 Sv.

a) $28.5^{\circ} \mathrm{S}$

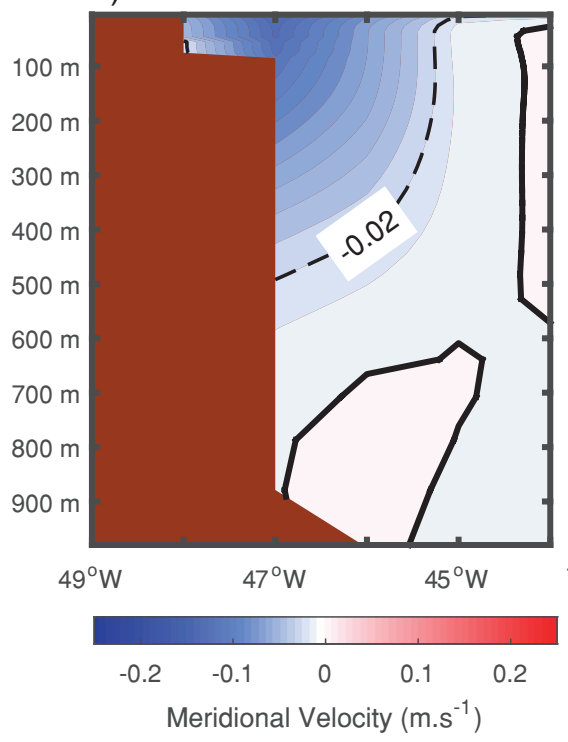

b)

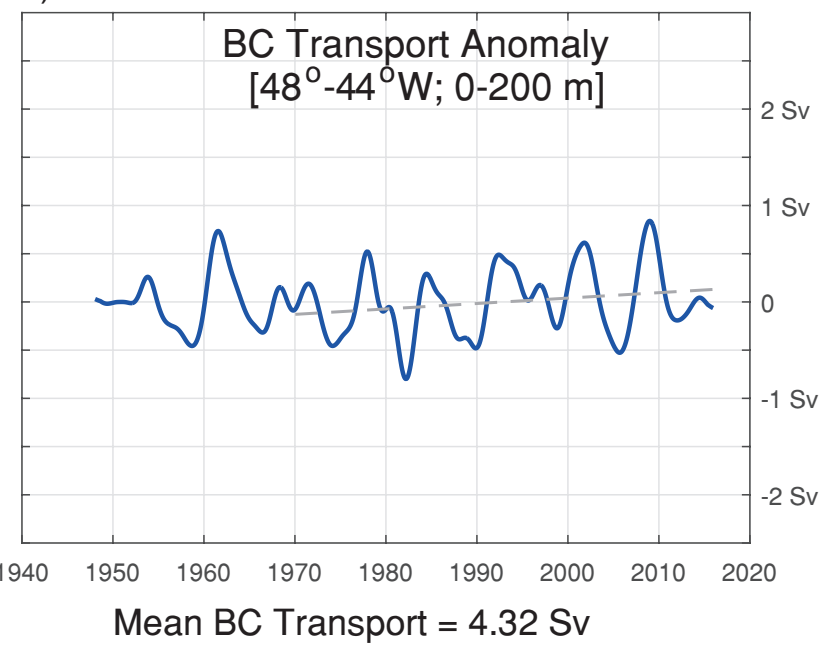

Figure 18: | BC vertical profile characterization and transport time series. | (a) BC mean vertical profile across $28.5^{\circ} \mathrm{S}$ represented by the $1948-2015$ average meridional velocity field along $49^{\circ}-44^{\circ} \mathrm{W}$ longitude and up to $980 \mathrm{~m}$ depth. The southward flow is indicated by the negative values in blue. The zero-velocity line is marked in bold and the $|0.02| \mathrm{m}^{-\mathrm{s}^{-1}}$ contour used for reference as in Fig. 16 is indicated by the dashed lines. (b) Low-passed time series of the respective southward transport fluctuations at $28.5^{\circ} \mathrm{S}$ (along $48^{\circ}-44^{\circ} \mathrm{W}$ and above $200 \mathrm{~m}$ ) about its mean volume of $4.32 \mathrm{~Sv}$. 
a) $6.5^{\circ} \mathrm{S}$

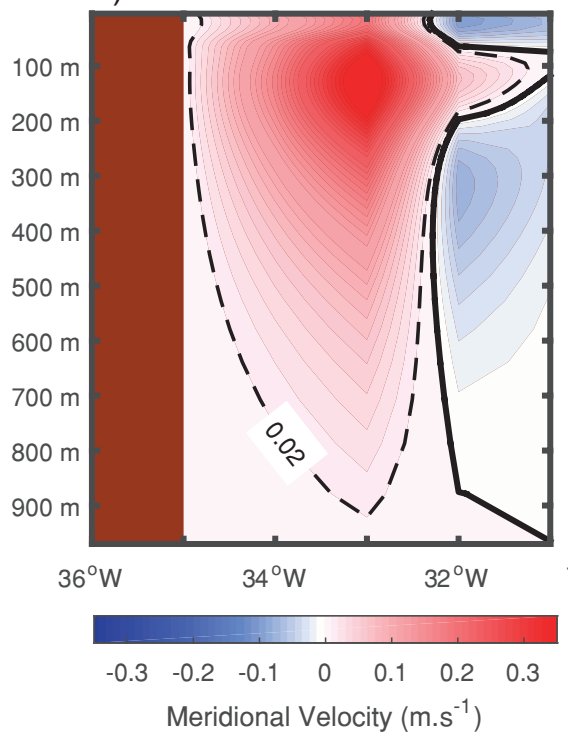

b)

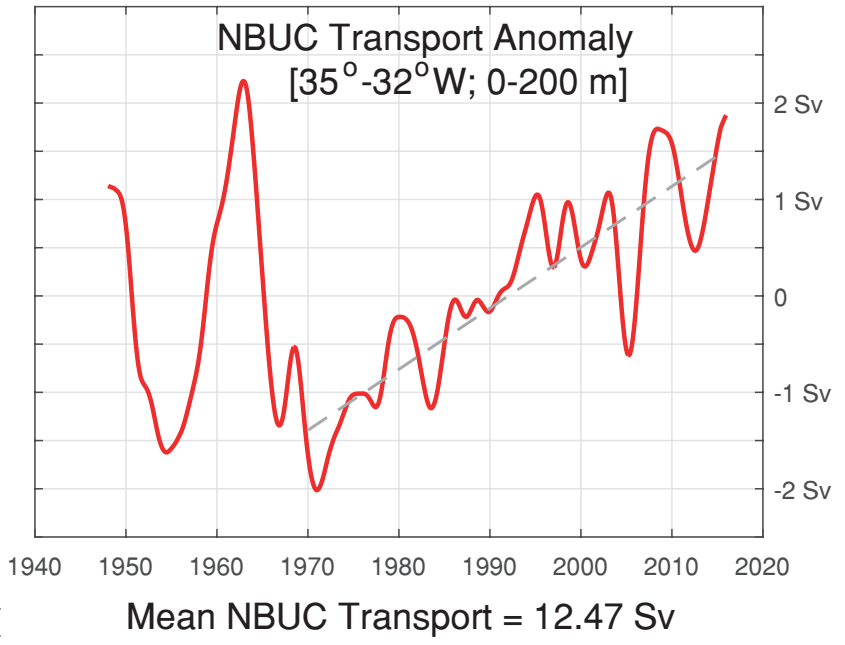

Figure 19: | NBUC vertical profile characterization and transport time series. | (a) NBUC mean vertical profile across $6.5^{\circ} \mathrm{S}$ represented by the $1948-2015$ average meridional velocity field along $36^{\circ}-31^{\circ} \mathrm{W}$ longitude and up to $980 \mathrm{~m}$ depth. The northward flow is indicated by the positive values in red. The zero-velocity line is marked in bold and the $|0.02| \mathrm{m}_{.} \mathrm{s}^{-1}$ contour used for reference as in Fig. 16 is indicated by the dashed lines. (b) Low-passed time series of the respective northward transport fluctuations at $6.5^{\circ} \mathrm{S}$ (along $35^{\circ}-32^{\circ} \mathrm{W}$ and above $200 \mathrm{~m}$ ) about its mean volume of $12.47 \mathrm{~Sv}$.

The monthly anomalies of volume transports (i.e., not considering seasonal oscillations) of the SSEC and the NBUC present a peak-to-peak variability of about 1.53-1.58 Sv; while, with regard to the $\mathrm{BC}$, the corresponding value is only of $0.68 \mathrm{~Sv}$. As to the mean transport values, it was found $12.95 \mathrm{~Sv}$ and $12.47 \mathrm{~Sv}$ for the SSEC and the NBUC, respectively, while only 4.32 $\mathrm{Sv}$ for the BC. These values are in close agreement with the literature: R2007 found an average transport of $15 \mathrm{~Sv}$ for the SSEC and $14 \mathrm{~Sv}$ for the NBUC, across the same coordinates and between same transects, but integrated up to $400 \mathrm{~m}$; while for the $\mathrm{BC}$, across $22^{\circ} \mathrm{S}$, the authors found an average transport of $6 \mathrm{~Sv}$. Schott et al. (1998) found an average transport of $14.6 \mathrm{~Sv}$ for the NBUC across $5^{\circ} S$ (above the 26.8 isopycnal) and Stramma and Peterson (1990) found 16 Sv for the sSEC across $30^{\circ} \mathrm{W}$ (upper $400 \mathrm{~m}$ ). For the BC, Evans and Signorini (1985) found $5.5 \mathrm{~Sv}$ across $25^{\circ} \mathrm{S}$ (upper $400 \mathrm{~m}$ ), while Stramma et al. (1990) found $4 \mathrm{~Sv}$ across $20^{\circ} \mathrm{S}$ (upper $500 \mathrm{~m}$ ).

Finally, the long-term change of the volume transports reveal stronger currents after the 70's: the SASG northern (SSEC) and western (BC) limbs strength increase by $2.90 \mathrm{~Sv}$ and $0.26 \mathrm{~Sv}$ (or $0.32 \mathrm{~Sv}$, if considered the period after 1980), respectively. The linear trends shown in Figures 17 and 18 are statistically significant at the $95 \%$ confidence level). This finding is consistent with the results from Section 3.3, which suggest an intensified gyre circulation.

However, the increase in the northward transport with the NBUC is of the same magnitude as that of the SSEC transport, of $2.90 \mathrm{~Sv}^{5}$. The time series of these standardized anomalies are even highly correlated, with a coefficient of 0.87 between the low-passed time series (Figure

\footnotetext{
level.

${ }^{5}$ All the 1970-2015 liner trends, in SSEC, BC and NBUC transports, are statistically significant at the $95 \%$ confidence
} 
20) and of 0.75 between monthly anomalies (not shown). This indicates that most of the SSEC transport increase is being destined towards the equator and the northern hemisphere, through the NBUC.

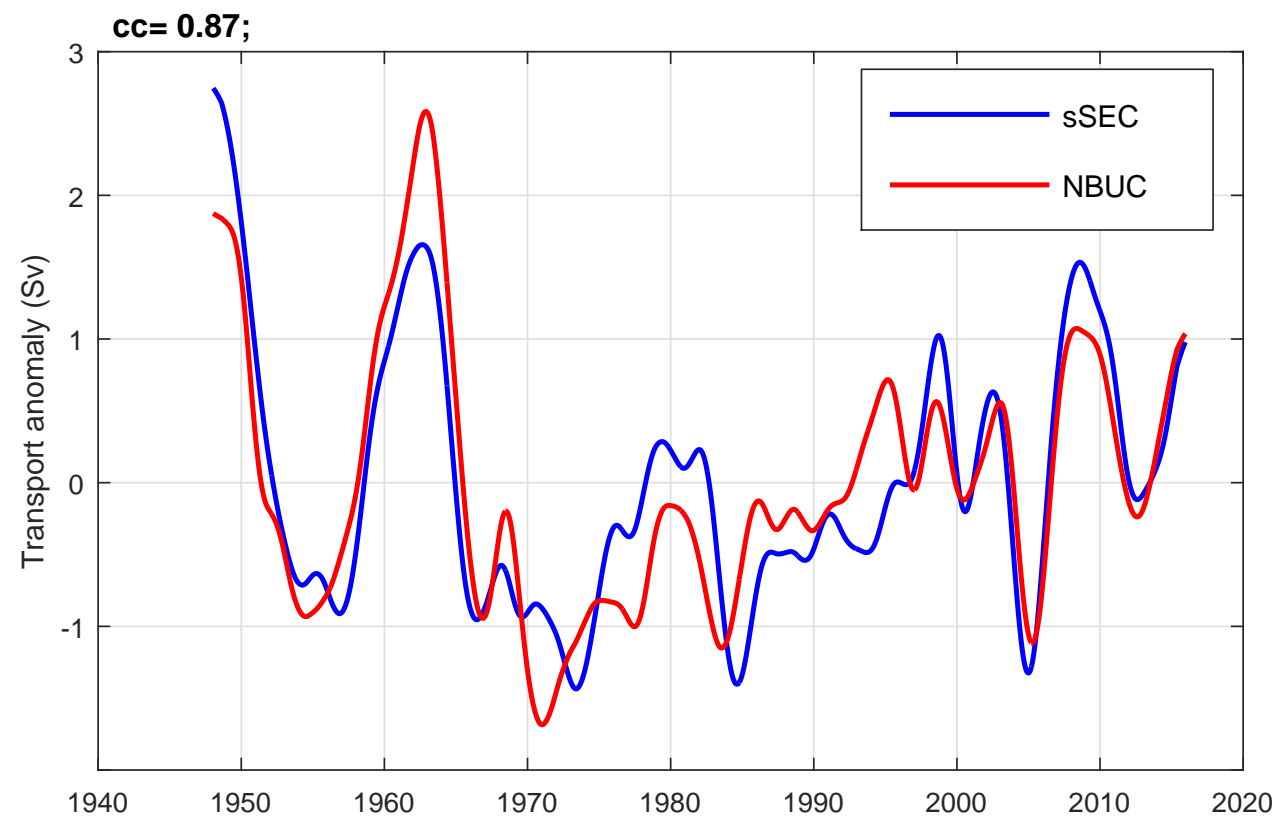

Figure 20 | Highlights of the synchrony between SSEC and NBUC transport anomalies. Comparison of the (standardized, low-passed) time series of the SSEC (blue, same as in Fig. 17) with the NBUC anomalies (red, same as in Fig. 19). The value on top of the plot indicates the correlation coefficient between the series.

Several studies have linked variations in the NBUC transport with the AMOC strength, considering it is inserted in the surface return flow destined to feed the North Atlantic heat sink (e.g., Zhang et al., 2011; Chang et al., 2008; Vellinga and Wu, 2004).

To investigate this hypothesis, the basin-integrated MOC transport is derived for the same latitude as the NBUC estimated transport $\left(6.5^{\circ} \mathrm{S}\right)$ as well as for the latitude where mooring arrays are deployed in order to monitor the AMOC - at $26.5^{\circ} \mathrm{N}$. 


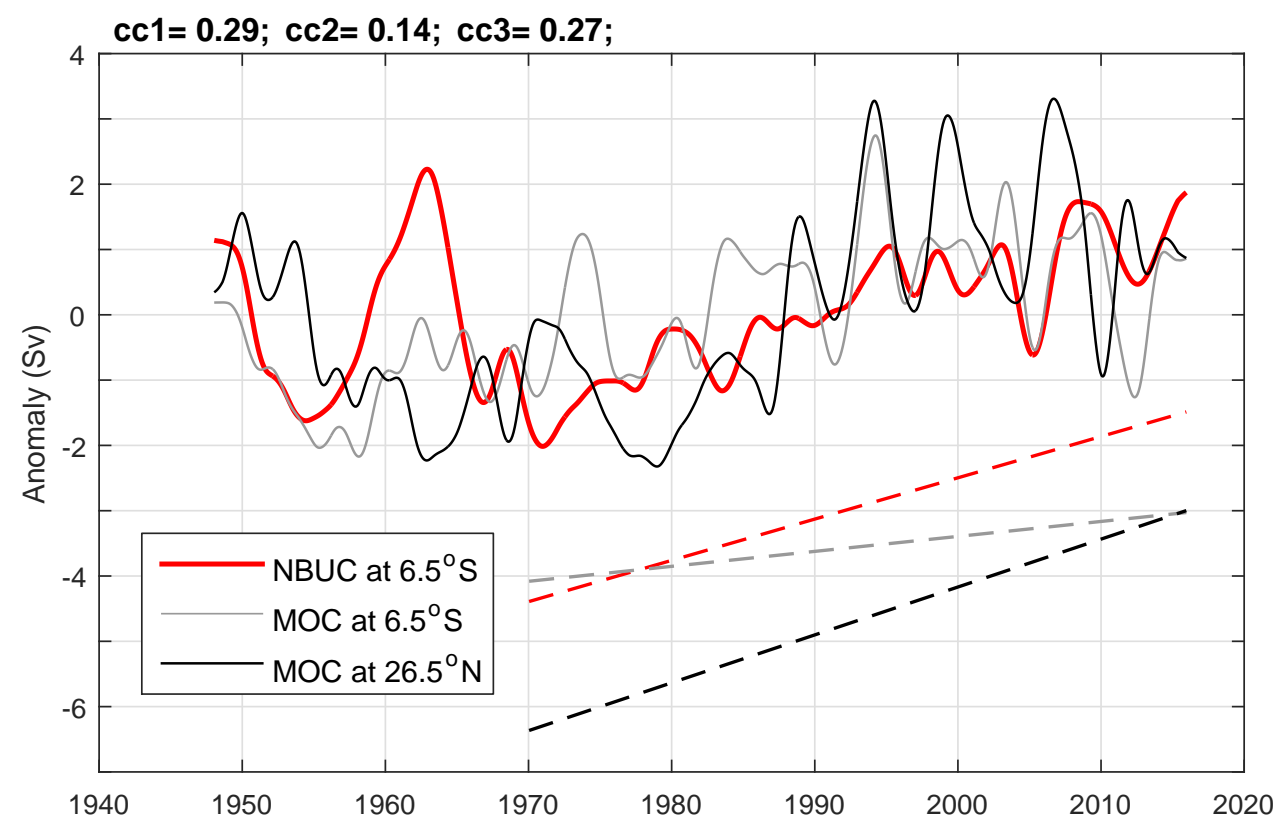

Figure 21 Attribution of NBUC transport increase to MOC intensification. | Comparison of the (low-pass-filtered) time series of the NBUC anomalies (red) at $6.5^{\circ} \mathrm{S}$ with the corresponding MOC anomalies at this latitude (light gray) and the MOC anomalies at $26.5^{\circ} \mathrm{N}$ (black). Both MOC streamfunctions are vertically integrated above 1000-m depth; their time series are scaled by a factor of $10^{-6}$. The dashed lines indicate the respective linear trends for the period 1970-2015, which are all statistically significant at the $95 \%$ confidence level. Values on top of the plot indicate the correlation coefficient between the normalized, detrended time series: the NBUC transport and the $\mathrm{MOC}$ at $6.5^{\circ} \mathrm{S}$ (cc1); the NBUC transport and the MOC at $26.5^{\circ} \mathrm{N}$ (cc2); and between the $\mathrm{MOC}$ at $6.5^{\circ} \mathrm{S}$ and the MOC at $26.5^{\circ} \mathrm{N}$ (cc3).

Both resulting time series yield increasing northward MOC recirculation after the 70's; nevertheless, the MOC streamfunction at $26.5^{\circ} \mathrm{N}$ increases at a rate similar to that of the NBUC transport (total increase of $3.37 \mathrm{~Sv}$, against $1.05 \mathrm{~Sv}$ for the MOC at $6.5^{\circ} \mathrm{S}$ - Figure 21). 


\subsubsection{Barotropic Transports}

Time series of the barotropic transports were derived for the same locations as for the total transports shown in Section 3.4.1, in the case of the SSEC, BC and NBUC (at $30^{\circ} \mathrm{W}, 28.5^{\circ} \mathrm{S}$ and $6.5^{\circ} \mathrm{S}$, respectively). Additionally, time series were also derived for: 1) a considerably wider meridional band for the SSEC transport at $10^{\circ} \mathrm{W}$ which covers nearly the whole climatological extent of the negative BSF field within the SASG; 2,3 ) a southerly preceding (succeeding) transect along the coast after the SSEC bifurcation for the NBUC (BC) at $\left.10.5^{\circ} \mathrm{S}\left(34.5^{\circ} \mathrm{S}\right) ; 4,5\right)$ a zonal (meridional) transect at $50.5^{\circ} \mathrm{S}\left(30^{\circ} \mathrm{W}\right)$ for the positive barotropic transport of the MC (SAC), outside the SASG domain delimited by the BSF0.

Figure 22 shows all the transects used to derive the barotropic transport time series mentioned above, which are displayed in Figure 23. Table 8 lists the magnitude of increase in the barotropic transports associated with periods of positive linear trends in each of the time series.

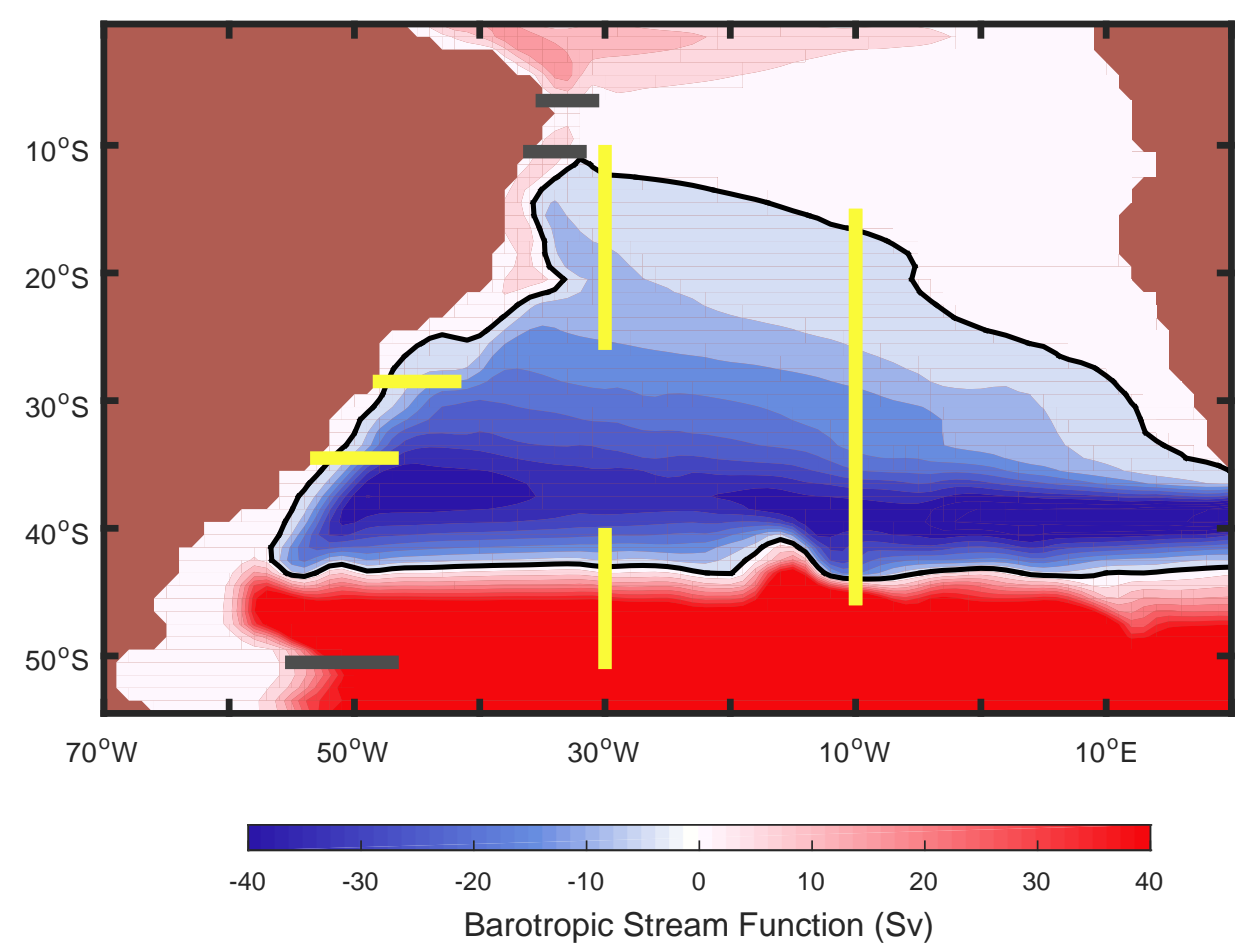

Figure 22 | Climatological BSF field (1948-2015). | Solid yellow (gray) lines represent transects used to derive the barotropic transport time series of SASG boundary currents (of SAO currents outside the subtropical gyre). Contours are every $5 \mathrm{~Sv}$.

Since the barotropic transport is a result of full-depth integration, it is expected that its magnitude (listed in Table 8) exceeds that of the total transports. The comparison is made in terms of percentage increase. 

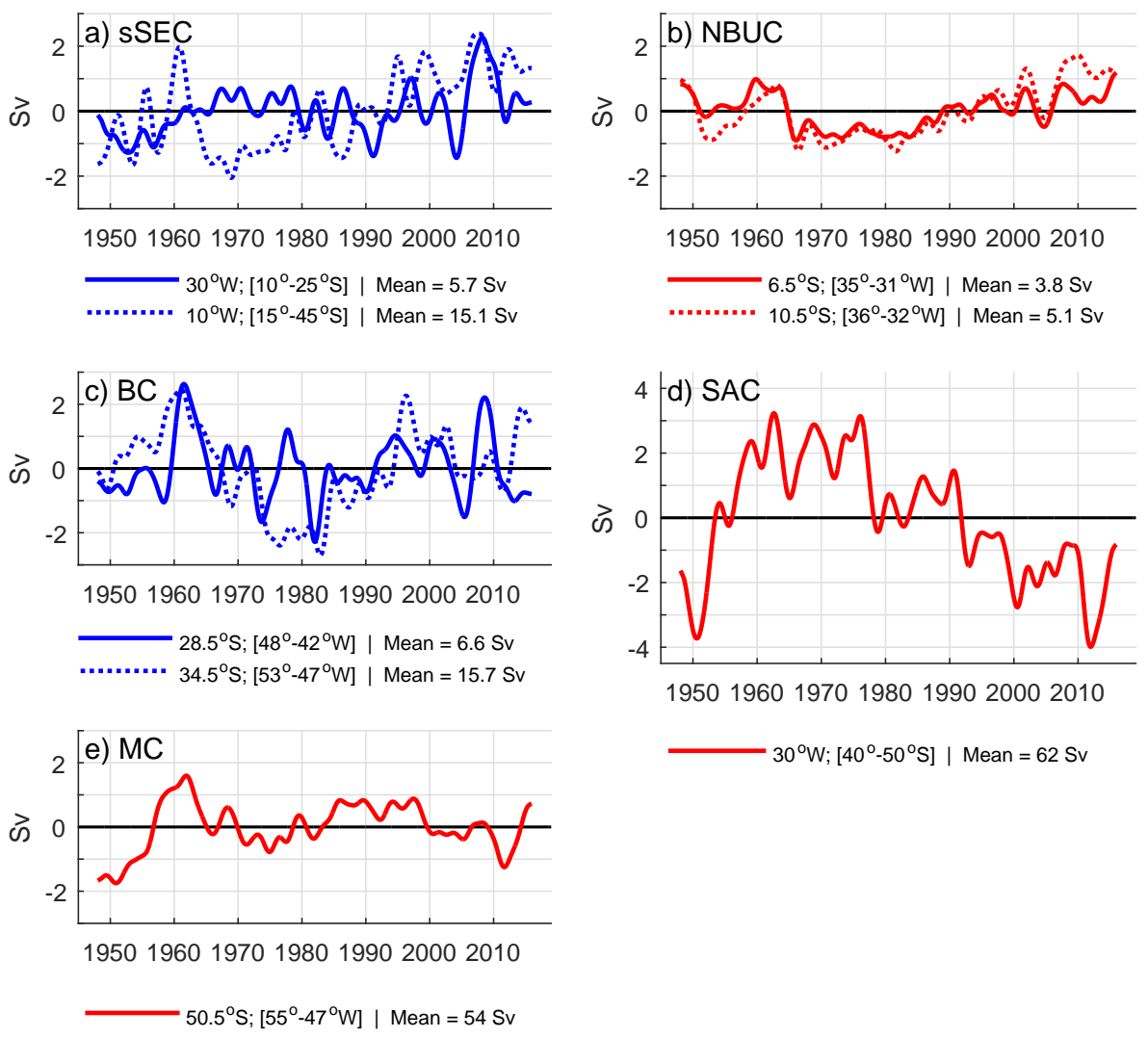

Figure 23 | SAO barotropic transport variation. | Low-passed anomalies of the barotropic transport of SAO currents at the locations indicated in Figure 22.

Table 8: Total increase in barotropic transports corresponding to linear trends from the time series in Fig. 23. The linear trends are all statistically significant at the $95 \%$ confidence level.

\begin{tabular}{lcc}
\hline \multicolumn{1}{c}{ Time series } & Period & Total increase \\
\hline a) SSEC $\left(10^{\circ} \mathrm{W}\right)$ & $1970-2015$ & $3.28 \mathrm{~Sv}$ \\
b) NBUC $\left(6.5^{\circ} \mathrm{S}\right)$ & $1970-2015$ & $1.54 \mathrm{~Sv}$ \\
b) NBUC $\left(10.5^{\circ} \mathrm{S}\right)$ & $1970-2015$ & $2.69 \mathrm{~Sv}$ \\
c) BC $\left(28.5^{\circ} \mathrm{S}\right)$ & $1980-2015$ & $0.58 \mathrm{~Sv}$ \\
c) BC $\left(34.5^{\circ} \mathrm{S}\right)$ & $1980-2015$ & $2.50 \mathrm{~Sv}$ \\
d) SAC $\left(30^{\circ} \mathrm{W}\right)$ & $1960-2015$ & $5.36 \mathrm{~Sv}$ \\
\hline
\end{tabular}


Although the barotropic transport of the SSEC at $30^{\circ} \mathrm{W}$ does not present a long-term change, at $10^{\circ} \mathrm{W}$ a considerable increase can be identified after the 70 's, of $23.62 \%$, comparable to that of the total transport of the SSEC at $30^{\circ} \mathrm{W}$, from Section 3.4.1, which is of $24.12 \%$. The increase in the barotropic transport of the NBUC $\left(52.51 \%\right.$ across $6.5^{\circ} \mathrm{S}$ and $69.33 \%$ across $\left.10.5^{\circ} \mathrm{S}\right)$ is more pronounced than that of the total transport $\left(26.26 \%\right.$ across $\left.6.5^{\circ} \mathrm{S}\right)$. The total transport of the BC in Section 3.4.1 increased only by 7.67\%; the modest increase holds for the barotropic transport across this same latitude as well $(9.52 \%)$, while across $34.5^{\circ} \mathrm{S}$, the increase in the barotropic transport is almost twice as big (17.21\%). The decrease in SAC barotropic transport at $30^{\circ} \mathrm{W}$ (of $8.28 \%$ ) could be interpreted as a poleward displacement of the gyres' system. As the barotropic transport of the SAC was derived using only positive values of the barotropic stream function, with a southward migration of the zonal current band, the occurrence of positive BSF values dropped, as they were being replaced by negative BSF values from within the gyre. The positive barotropic transport of the MC, which flows against the poleward BC, shows nearly subdecadal fluctuations around its mean value - providing no information about long-term variations. 


\subsubsection{Linkage between SBL variability and currents' transports}

The bifurcation latitude variability is a manifestation of changes in the flow of the currents involved. It is observed that when the SBL shifts southward (northward) the NBUC transport increases (decreases) and the BC transport decreases (increases) (R2007). Figure 24 explores the relationship between the SBL and the SEC, NBUC and BC transports time series.

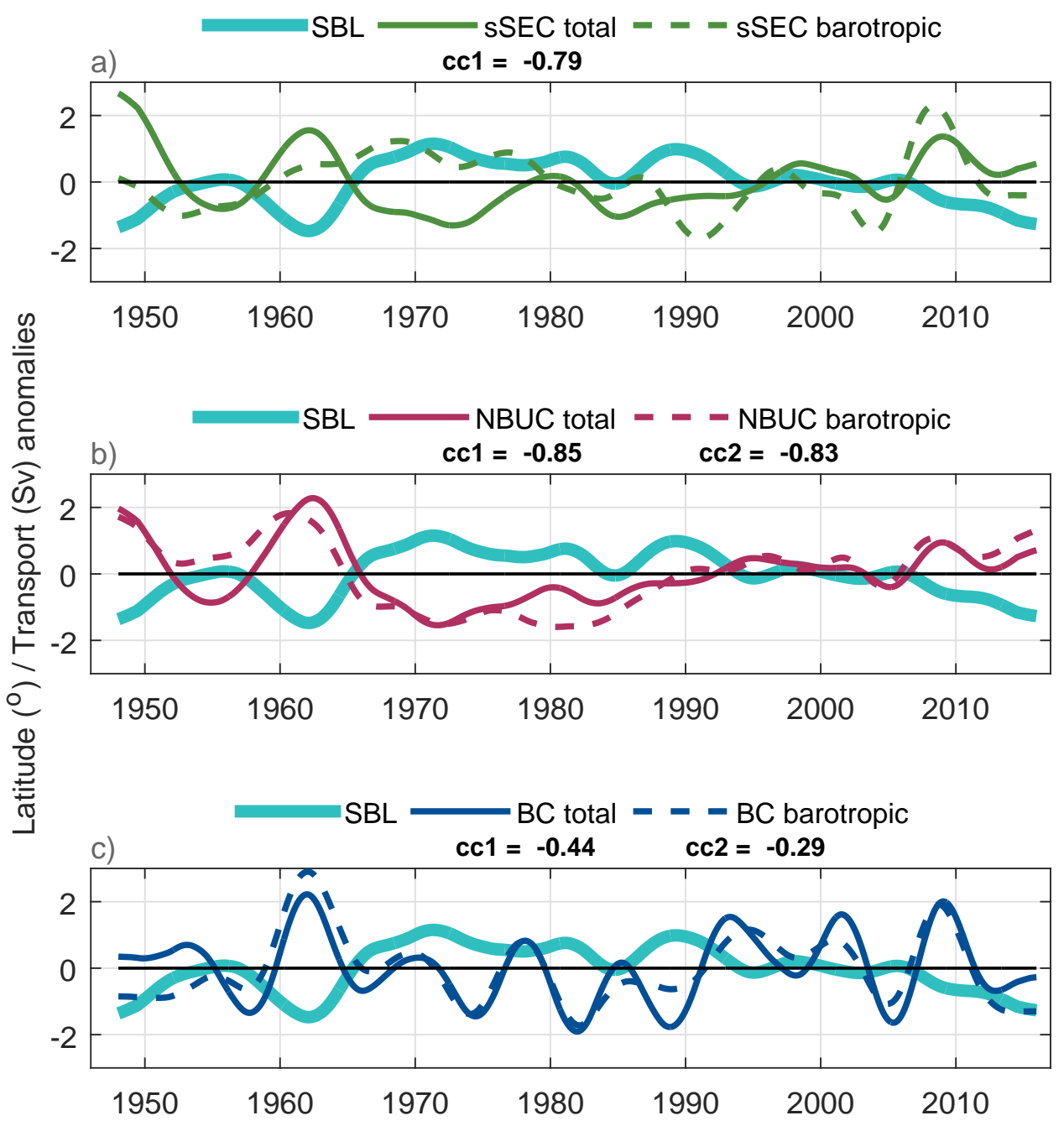

Figure 24 | SSBL relationship with sSEC, NBUC and BC transports. | Low-passed (35-month), standardized time series of the SSBL (in light blue, for all panels) and the total (solid lines) and barotropic (dashed lines) transports of (a) the SSEC across $30^{\circ} \mathrm{W}$, (b) the NBUC across $6.5^{\circ} \mathrm{S}$ and (c) the $\mathrm{BC}$ across $28.5^{\circ} \mathrm{S}$. Values on top of the plot indicate the correlation coefficient between the series: $\mathrm{cc} 1$ (cc2) quantifies the relation between the SBL and the total (barotropic) transports.

Our results show that the SBL and the NBUC are well correlated: as the SSEC bifurcates in southerly positions, the northward NBUC transport increases, and vice versa (Figure 24b). The correlation coefficient (cc) is nearly the same for total and barotropic transports $(-0.85$ and -0.83 , 
respectively). The SBL and the SSEC total transport show a strong relationship as well ( $\mathrm{CC}=-$ $0.79)$ : as the SSEC total transport increases, the impinging SSEC bifurcates in southerly positions (Figure 24a). On the other hand, the barotropic sSEC transport yields a negligible relation with the SBL; since there is a transition between a positive and negative relationship along the total period, the $\mathrm{cc}$ is insignificant. When comparing the $\mathrm{BC}$ transport response to the $\mathrm{SBL}$ variation, however, a counter-intuitive relation is observed: as the SBL migrates southward (northward), the BC transport increase (decrease) (Figure 24c). This is contrary to what was expected.

The SBL, therefore, presents an indirect relationship with the SSEC, NBUC and BC transports. This relation holds from interannual to subdecadal variability and long-term trends (the correlation coefficients between the 15-month low pass-filtered time series are almost as high, if not higher). The 35-month low-pass is applied in order for the relationship to be visually clearer: after the 70's, the SBL is observed to continuously migrate to the south up to the early 21st century; while sSEC, NBUC and BC transports all show an intensification.

This leads to the idea that more waters are arriving against the western boundary with the SSEC, which are, in part, bending southward and contributing to the modest BC transport increase; nevertheless, the actual bulk of it, is really heading towards the north along with the NBUC and, therefore, consisting of the prevailing mechanism which ends up pushing the bifurcation latitude poleward. 


\subsection{Last Millennium change perspective}

In this Section, we address the relative amplitude of the observed changes along the 20th-21st century transition, in relation to a longer record - such as the period covered by the Last Millennium. In order to accomplish this, we analyze the results from the Last Millennium Ensemble experiment (CESM-LME) to understand the past physical behaviour of the SAO.

\section{The Last Millennium - Short theoretical background:}

The climate variability of the period corresponding to the Last Millennium (e.g., Jones and Mann, 2004; Jones et al., 2001 encompasses three major climatic episodes: the "Medieval Climate Anomaly", the "Little Ice Age" and the "Recent Warming" (Diaz et al., 2011; Mann et al., 2009). By studying the records of climate variability and forcing mechanisms in the recent past, it is possible to establish how the climate system varied before anthropogenic forcing became significant. Natural forcing mechanisms will continue to operate in the 21 st century, and will play a role in future climate variations, so regardless of how anthropogenic effects develop it is essential to understand the underlying background record of forcing and climate system response (Bradley et al., 2003).

The results derived from CESM-LME show that, during the Last Millennium the observed changes in the post-industrial period and mainly along the passage from the 20th into the 21st century reveal to be unprecedented.

SBL

The SBL time series both at the surface and at $100 \mathrm{~m}$ (Figure 25a, b and 25c, d; respectively) show a southward migration starting during the mid-late 19th century (the vertical green dashed line demarks the year of 1850 in Figure 25a, c), from where it progressively enhances, reaching positions far out of the range of natural variability within the long record, by the end of the 20th century (where the vertical blue dashed line demarks the year of 1980).

Despite varied higher-frequency oscillations, all ensemble members (in light gray) undergo the described southward migration. Only the time series of the control-run (CTRL, in yellow) remains around the mean position, strongly suggesting that the recent poleward shift of the SBL is related to human-induced climate change forcings. Therefore, the signal expressed by the average of the 10 ensemble members (the Ensemble Mean) is clear. And the spread across the members, used to quantify uncertainties (denoted by red and blue time series in Figure 25b, $d$ $\left.{ }^{6}\right)$, reduces toward the end of the time series at the surface (top-right panel), corroborating the southward migration.

\footnotetext{
${ }^{6}$ The spread of the ensemble members is calculated following Zhai et al. (2014): for the temporally varying variables, the spread in each month among ensemble members is defined as the standard deviation of the departure of ensemble members from the Ensembles' mean in that month.
} 

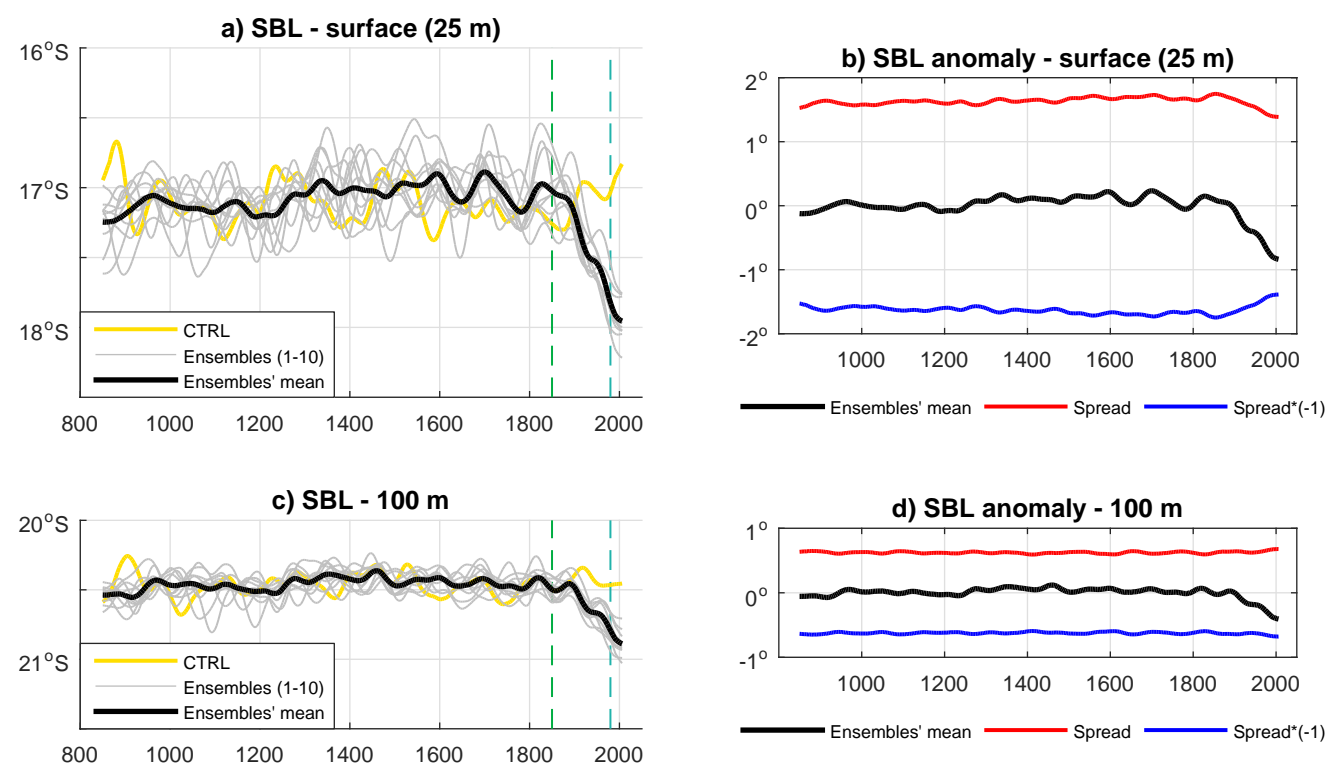

Figure 25 | SBL time series for the Last Millennium. | Low-passed (30-yr) time series of the $\mathrm{SBL}$ at the surface (the SSBL - a, b) and at $100 \mathrm{~m}(\mathbf{c}, \mathbf{d})$. Subplots (a, c) show the time series for the 10 ensemble members of the CESM-LME (in gray) plus the control-run (CTRL, yellow) - which is not subject to external forcings. Solid black-bold lines denote the average of the 10 ensembles members (the Ensembles' mean). Vertical dashed green (light blue) line indicates the year of 1850 (1980). Subplots (b, d) show the Ensembles' mean anomaly time series with the spread (red) and spread times -1 (blue).

In the CESM-LME results, the southward shift of the SBL is also accompanied by a rise in the northward NBUC volume transport as well as in the MOC streamfunction at the same latitude $\left(6.5^{\circ} \mathrm{S}\right)$. As can be seen in Figure 26, the maximum NBUC transport and MOC strength observed since the late 20th century were never matched in the last millennium, and thus represent an exceptional event. 


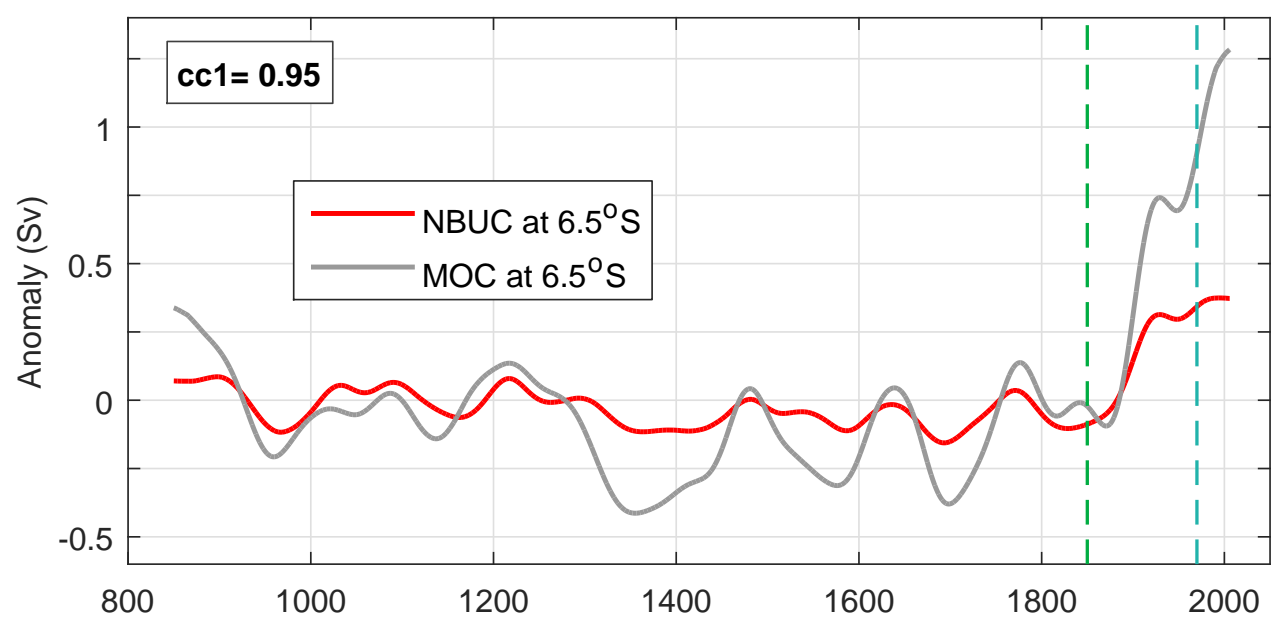

Figure 26 | Late NBUC transport increase and MOC intensification relative to the Last Millennium. | Low-passed (30-yr) anomalies of the NBUC transport (red) at $6.5^{\circ} \mathrm{S}$ and the corresponding MOC streamfunction at this latitude (light gray). As in Figure 21, the MOC streamfunction is vertically integrated above $1000-\mathrm{m}$ depth and its time series is scaled by a factor of $10^{-6}$. The correlation coefficient between the standardized time series is indicated by cc1. Vertical dashed green (light blue) line indicates the year of 1850 (1980).

\section{SASG dynamics}

In this section, the dynamical fields are zonally averaged for: the Last Millennium climatology (850-1850), a climatology covering the 20th century (1850-2005) and the 1980-2005 climatology (Figure 27). All fields manifest pronounced changes during the late 20th century (1980-2005) which contrast with the 850-1850 and 1850-2005 climatologies. 


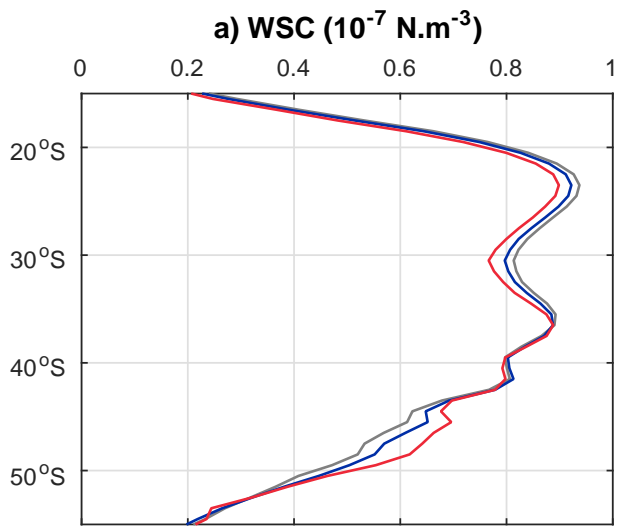

c) $\mathrm{SSH}(\mathrm{cm})$

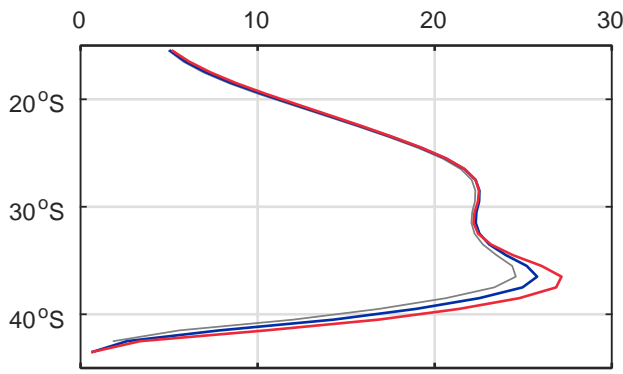

LM (0850-1850)

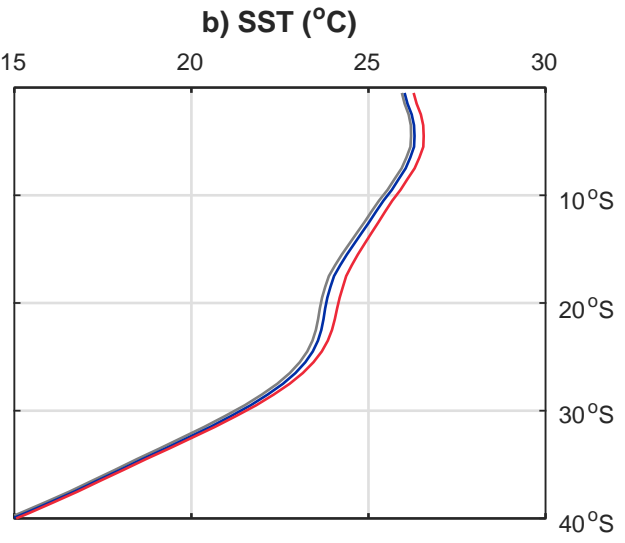

d) BSF (Sv)

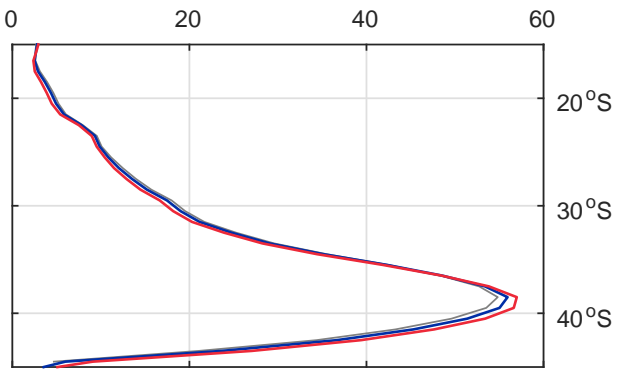

last 25 years $(1980-2005)$

Figure 27 | Recent transition in South Atlantic zonally averaged fields. | (a) Wind Stress Curl, along $30^{\circ}-10^{\circ} \mathrm{W}$; (b) Sea Surface Temperature, along $40^{\circ}-20^{\circ} \mathrm{W}$; (c) Sea Surface Height, along $35^{\circ}-25^{\circ} \mathrm{W}$ and (d) Barotropic Stream Function, along $50^{\circ}-20^{\circ} \mathrm{W}$. The gray line represents the Last Millennium climatology (850-1850), blue line represents roughly the 20th century climatology (1850-2005) and red line the climatology from the last 25 years of the CESM-LME record (19802005).

The change pattern of the WSC resembles that described by Pontes et al. (2016), using a set of 19 models from the Coupled Model Intercomparison Project phase 5: there is a weakening between approximately $15^{\circ} \mathrm{S}$ and $35^{\circ} \mathrm{S}$ and a concurrent strengthening south of this region. The increase in SST occurs especially within the tropics, north of $30^{\circ} \mathrm{S}$; while the increase in SSH resembles that of in the BSF field - centered in the regions of maximum values, just north of $40^{\circ} \mathrm{S}$. 
a) Latitude of Max. WSC

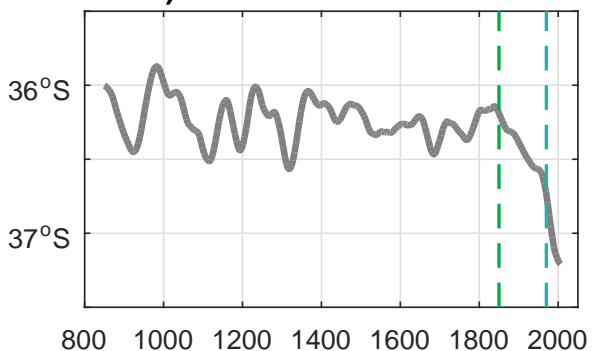

c) Latitude of Max. SSH

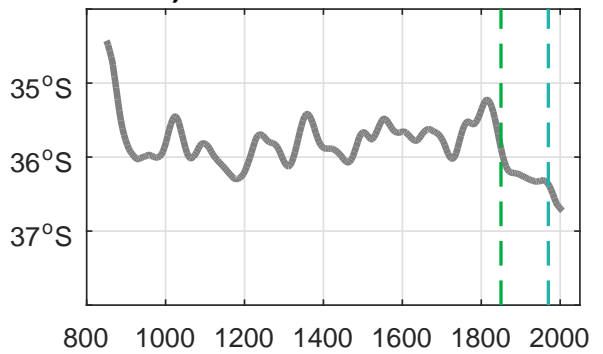

e) Latitude of Max. |BSF|

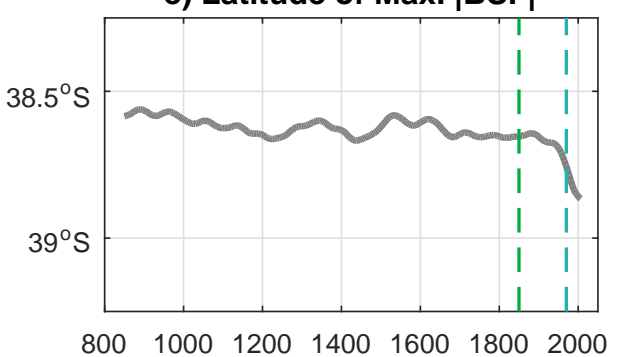

b) SVTOn

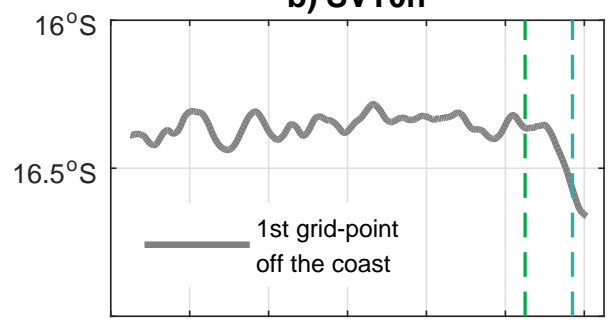

800100012001400160018002000

d) $\mathrm{SSHOS}$

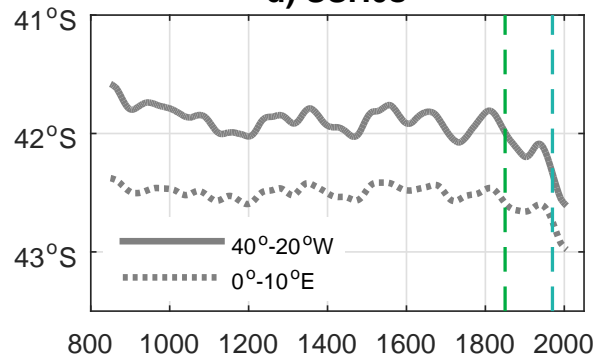

f) BSF0s

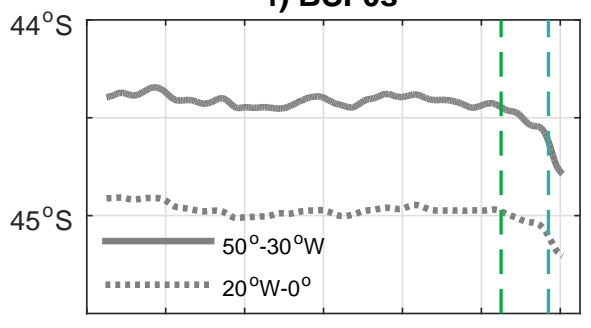

$800 \quad 1000 \quad 1200 \quad 1400 \quad 1600 \quad 18002000$

Figure 28 | Southward shift of the SASG system relative to the Last Millennium. | Lowpassed latitudes of: (a) maximum WSC, (c) SSH and (e) BSF; and of SASG dynamical boundaries - (b) SVTO at northern limb, (d) SSHO and (f) BSFO at southern limbs. Vertical dashed green (light blue) line indicates the year of 1850 (1980).

From Figure 28 one can note that starting around 1850, the latitudes associated with the wide-ranging dynamical positions of the gyre (i.e., latitudes of maximums approximately in the center and of contours at the boundaries) seem to start a subtle drift towards the south. In the late 60's, the southward drift progresses more intensely.

It should be noted that the time series in the left (right) column from Figure 28 are analogous to those of the right (left) column from Figure 13 (15) for the CESM-OCN, in Section 3.3. 


\section{Conclusions and Discussion}

The patterns of gyre-scale flow in global subtropical oceans seem to be changing, as do the associated atmospheric forcings under anthropogenic global warming. Using the ocean component of the CESM and the fully coupled CESM-LME experiment, the results presented here support our hypothesis that the SAO is indeed subject to these changes.

More specifically, it has been suggested that midlatitude subtropical gyres, especially those of the Southern Ocean, are concurrently spinning up their circulations whilst drifting to southward positions, in response to changes in the surface wind stress field (Roemmich et al., 2007; Cai et al., 2005; Cai, 2006; Saenko et al., 2005; Zhang et al., 2013; Li et al., 2013).

For the CESM-OCN period ranging the mid 20th into the early 21st century (1948-2015), signals in WSC, SSH and BSF fields point to an intensification of the subtropical gyre circulation, inferred from increasing values of these diagnostic variables within their dynamical rims of the SASG domain (i.e. their zero contours) which confine the governing dynamics of subtropical SAO circulation: positive WSC, positive SSH and negative BSF. A synchronous poleward migration of the system is also indicated by the signals in these basin-scale dynamical fields. This is demonstrated by significant differences between the mean climatologies straddling the 80 's, as well as linear trends in time series of the latitude of WSC, SSH and BSF core-maximums and null-edges (generally defined by the zonally averaged maximums and zero contours, respectively).

Although it would be expected that the gyre's spin up and associated BC transport increase would push the SASG northern limb equatorward, it has been found that the mean position of the SBL at the northwestern boundary of the gyre shifted southward from $11.5^{\circ} \mathrm{S}$ to $15^{\circ} \mathrm{S}$, at a rate of $0.051^{\circ} \mathrm{S} \mathrm{yr}^{-1}$. This is twice as big than the shift of its Pacific Ocean counterparts (studied by Chen and Wu, 2012 and Zhai et al., 2014).

Besides being in agreement with the reported poleward movement of the whole system, this southward shift of the SBL is largely attributable to a substantial increase in the northward transport of the NBUC along the path of the upper branch of the AMOC. When deriving the basinintegrated MOC transport both for the same latitude where derived the NBUC transport and at the $26.5^{\circ} \mathrm{N}$ latitude of the RAPID-MOC observing system, a considerable recirculation increase is found consistent with the NBUC intensification. This suggests that the SBL southward shift, accompanied by the NBUC strengthening, might be related to variations in the MOC. Modifications of the water masses participating in the return flow within the South Atlantic can potentially lead to alterations of the thermohaline circulation and the associated meridional heat and freshwater fluxes.

Finally, the perspective of a longer time frame provided by the CESM-LME experiment reveals that, lately, the observed changes in the SBL and the SASG dynamics have reached proportions with no precedents since the year of 850 .

Here we have inferred a spinned-up gyre circulation associated with increased torque over the basin (through signals in the WSC field by Sverdrup dynamics and through increased 
barotropic transport and sea level anomalies). We must clarify that the focus of this work is related to a large-scale scenario, associated with low-frequency variability; however, exist anomalous, higher-frequency variations which are superimposed to the mean circulation, as well as regional scale signals which are embedded in these concurrent circulation changes and are out of the scope of this work.

Our results confirm that important changes are taking place in the evolving upper-ocean circulation, at least with respect to the SAO. The SASG spin up and poleward shift are likely to have important consequences to the global climate system as well as regional climate and ecosystems.

As mentioned by Bryden et al. (2012), the key issue for the next years is to understand how the ocean circulation varies on interannual to decadal time scales and to quantify the impacts of varying ocean circulation on climate and biological productivity, for instance. This work was intended to investigate the main large-scale features that constitute the SAO subtropical circulation and to describe the associated results and spatiotemporally varying signals, providing a dynamical framework to identify potential new states of the system in view of ongoing global climate changes.

In any case, our conclusion that in the late 20th into early 21st century the time series of SAO dynamical signals reached levels that had rarely, if ever, been exceeded in (at least) the preceding 1000 years seems to be an extremely robust result from the simulation results here analyzed; indicating that this recent short record is subject to unique conditions. 


\section{References}

Alory, G., S. Wijffels, and G. Meyers (2007, jan). Observed temperature trends in the Indian Ocean over 1960-1999 and associated mechanisms. Geophysical Research Letters 34(L02606), 1-6.

Andreas Oschlies (2001). NAO-induced long-term changes in nutrient supply to the surface waters of the North Atlantic. Geophysical Research Letters 28(9), 1751-1754.

Arblaster, J. M., G. A. Meehl, and D. J. Karoly (2011). Future climate change in the Southern Hemisphere: Competing effects of ozone and greenhouse gases. Geophysical Research Letters 38(2), 1-6.

Beal, L. M., W. P. M. De Ruijter, A. Biastoch, and R. Zahn (2011, apr). On the role of the Agulhas system in ocean circulation and climate. Nature 472, 429-436.

Biastoch, A., C. W. Böning, F. U. Schwarzkopf, and J. R. E. Lutjeharms (2009, nov). Increase in Agulhas leakage due to poleward shift of Southern Hemisphere westerlies. Nature 462, 495-498.

Boebel, O., R. E. Davis, M. Ollitrault, R. G. Peterson, P. L. Richardson, C. Schmid, and W. Zenk (1999). The Intermediate Depth Circulation of the Western South Atlantic. Geophysical Research Letters 26(21), 3329-3332.

Bradley, R., K. R. Briffa, J. Cole, and T. J. Osborn (2003). The climate of the last millenium. Paleoclimate, Global Change and the Future, 105-141.

Bryden, H. L., C. Robinson, and G. Griffiths (2012). Changing currents: a strategy for understanding and predicting the changing ocean circulation. Philosophical Transactions of The Royal Society A 370, 5461-5479.

Cabos, W., D. V. Sein, J. G. Pinto, A. H. Fink, N. V. Koldunov, F. Alvarez, A. Izquierdo, N. Keenlyside, and D. Jacob (2016, aug). The South Atlantic Anticyclone as a key player for the representation of the tropical Atlantic climate in coupled climate models. Climate Dynamics, 1-19.

Cai, W. (2006). Antarctic ozone depletion causes an intensification of the Southern Ocean supergyre circulation. Geophysical Research Letters 33(3), L03712.

Cai, W. and T. Cowan (2007). Trends in Southern Hemisphere circulation in IPCC AR4 models over 1950-99: Ozone depletion versus greenhouse forcing. Journal of Climate 20(4), 681-693.

Cai, W., G. Shi, T. Cowan, D. Bi, and J. Ribbe (2005). The response of the Southern Annular Mode, the East Australian Current, and the southern mid-latitude ocean circulation to global warming. Geophysical Research Letters 32(L23706), 1-4. 
Chang, P., R. Zhang, W. Hazeleger, C. Wen, X. Q. Wan, L. Ji, R. J. Haarsma, W. P. Breugem, and H. Seidel (2008). Oceanic link between abrupt changes in the North Atlantic Ocean and the African monsoon. Nature Geoscience 1(7), 444-448.

Chen, Z. and L. Wu (2011). Dynamics of the seasonal variation of the North Equatorial Current bifurcation. Journal of Geophysical Research 116(C02018).

Chen, Z. and L. Wu (2012, jun). Long-term change of the Pacific North Equatorial Current bifurcation in SODA. Journal of Geophysical Research 117, C06016.

Chen, Z. and L. Wu (2015). Seasonal Variation of the Pacific South Equatorial Current Bifurcation. Journal of Physical Oceanography 45(6), 1757-1770.

Chen, Z., L. Wu, B. Qiu, S. Sun, and F. Jia (2014). Seasonal Variation of the South Equatorial Current Bifurcation off Madagascar. Journal of Physical Oceanography 44, 618-631.

Cirano, M., M. M. Mata, E. Campos, and N. Deiro (2006). a Circulação Oceânica De Larga-Escala Na Região Oeste Do Atlântico Sul Com Base No Modelo De Circulação Global - OCCAM. Revista Brasileira de Geofisica 24, 209-230.

Combes, V. and R. P. Matano (2014). Trends in the Brazil/Malvinas Confluence region. Geophysical Research Letters 41(24), 8971-8977.

Cunningham, S. A. and R. Marsh (2010). Observing and modeling changes in the Atlantic MOC. Wiley Interdisciplinary Reviews: Climate Change 1, 180-191.

de Ruijter, W. P. M., A. Biastoch, S. S. Drijfhout, J. R. E. Lutjeharms, R. P. Matano, T. Pichevin, P. J. van Leeuwen, and W. Weijer (1999). Indian-Atlantic interocean exchange: Dynamics, estimation and impact. Journal of Geophysical Research 104(C9), 20,885-20,910.

Delworth, T. and M. E. Mann (2000). Observed and simulated multi decadal variability in the Northern Hemisphere. Clim. Dyn. 16, 661-676.

Diaz, H. F., R. Trigo, M. K. Hughes, M. E. Mann, E. Xoplaki, and D. Barriopedro (2011, nov). Spatial and Temporal Characteristics of Climate in Medieval Times Revisited. Bulletin of the American Meteorological Society 92(11), 1487-1500.

Donners, J. and S. S. Drijfhout (2004). The Lagrangian view of South Atlantic interocean exchange in a global ocean model compared with inverse model results. Journal of Physical Oceanography 34(1986), 1019-1035.

Evans, D. L. and S. S. Signorini (1985). Vertical structure of the Brazil Current. Nature 315, 48-50. 
Ganachaud, A. (2003). Large-scale mass transports, water mass formation, and diffusivities estimated from World Ocean Circulation Experiment (WOCE) hydrographic data. Journal of Geophysical Research 108(C7), 6-1-.

Garzoli, S. L. (1993). Geostrophic velocity and transport variability in the Brazil-Malvinas Confluence. Deep-Sea Research Part I 40(7), 1379-1403.

Goni, G. J., F. Bringas, and P. N. DiNezio (2011, oct). Observed low frequency variability of the Brazil Current front. Journal of Geophysical Research 116, C10037.

Goni, G. J. and I. Wainer (2001). Investigation of the Brazil Current front variability from altimeter data. Journal of Geophysical Research 106(C12), 31,117-31,128.

Gordon, A. L. (1985). Indian-Atlantic Transfer of Thermocine Water. Science 227, 1030-1033.

Gordon, A. L. (1986). Interocean Exchange of Thermocline Water. Journal of Geophysical Research 91, 5037-5046.

Gordon, A. L. (1989). Brazil-Malvinas Confluence-1984. Deep Sea Research Part A, Oceanographic Research Papers 36(3), 359-384.

Gordon, A. L., R. A. Y. F. Weiss, W. M. Smethie, and M. J. Warner (1992). Thermociine and Intermediate Water Communication Between the South Atlantic and Indian Oceans. Journal of Geophysical Research 97(C5), 7223-7240.

Harper, S. (2000). Thermocline ventilation and pathways of tropical-subtropical water mass exchange. Tellus A 52(3), 330-345.

Holfort, J. and G. Siedler (2001). The Meridional Oceanic Transports of Heat and Nutrients in the South Atlantic. Journal of Physical Oceanography 31(1), 5-29.

Hu, D., L. Wu, W. Cai, A. S. Gupta, A. Ganachaud, B. Qiu, A. L. Gordon, X. Lin, Z. Chen, S. Hu, G. Wang, Q. Wang, J. Sprintall, T. Qu, Y. Kashino, F. Wang, and W. S. Kessler (2015). Pacific western boundary currents and their roles in climate. Nature 522(7556), 299-308.

Hunke, E. C., W. H. Lipscomb, A. K. Turner, N. Jeffery, and S. Elliott (2015). CICE : the Los Alamos Sea Ice Model Documentation and Software User's Manual LA-CC-06-012. pp. 115.

Hurrell, J. W., M. M. Holland, P. R. Gent, S. Ghan, J. E. Kay, P. J. Kushner, J.-F. Lamarque, W. G. Large, D. Lawrence, K. Lindsay, W. H. Lipscomb, M. C. Long, N. Mahowald, D. R. Marsh, R. B. Neale, P. Rasch, S. Vavrus, M. Vertenstein, D. Bader, W. D. Collins, J. J. Hack, J. Kiehl, and S. Marshall (2013, sep). The Community Earth System Model: A Framework for Collaborative Research. Bulletin of the American Meteorological Society 94(9), 1339-1360. 
International CLIVAR Project Office (2007). Report of the CLIVAR/OOPC/IAI Workshop on the South Atlantic Climate Observing System (SACOS). Technical report.

Jones, P. D. and M. E. Mann (2004). Climate over past mellinia. Reviews of Geophysics 42(RG2002), 1-42.

Jones, P. D., T. J. Osborn, and K. R. Briffa (2001, apr). The evolution of climate over the last millennium. Science (New York, N.Y.) 292(5517), 662-7.

Karl, D. M., R. R. Bidigare, and R. M. Letelier (2001). Long-term changes in plankton community structure and productivity in the North Pacific Subtropical Gyre: The domain shift hypothesis. Deep Sea Research Part II 48, 1449-1470.

Kendall, M. G. (1975). Rank Correlation Methods (4 ed.). London.

Kim, Y. Y., T. Qu, T. Jensen, T. Miyama, H. Mitsudera, H.-W. Kang, and A. Ishida (2004). Seasonal and interannual variations of the North Equatorial Current bifurcation in a high-resolution OGCM. Journal of Geophysical Research 109(C03040), 1-19.

Lawrence, D. M., K. W. Oleson, M. G. Flanner, P. E. Thornton, S. C. Swenson, J. Peter, X. Zeng, Z.-I. Yang, S. Levis, K. Sakaguchi, G. B. Bonan, and A. G. Slater (2009). Parameterization Improvements and Functional and Structural Advances in Version 4 of the Community Land Model. 3, 1-27.

Li, W., L. Li, M. Ting, Y. Deng, Y. Kushnir, Y. Liu, Y. Lu, C. Wang, and P. Zhang (2013). Intensification of the Southern Hemisphere summertime subtropical anticyclones in a warming climate. Geophysical Research Letters 40(22), 5959-5964.

Li, W., L. Li, M. Ting, and Y. Liu (2012). Intensification of Northern Hemisphere subtropical highs in a warming climate. Nature Geoscience 5(11), 830-834.

Lübbecke, J. F., N. J. Burls, C. J. C. Reason, and M. J. McPhaden (2014). Variability in the South Atlantic Anticyclone and the Atlantic Niño Mode*. Journal of Climate 27(21), 8135-8150.

Lumpkin, R. and S. Garzoli (2011, jan). Interannual to decadal changes in the western South Atlantic's surface circulation. Journal of Geophysical Research 116, 1-10.

Lumpkin, R. and K. Speer (2003). Large-Scale Vertical and Horizontal Circulation in the North Atlantic Ocean. Journal of Physical Oceanography 33, 1902-1920.

Malanotte-Rizzoli, P., K. Hedstromb, H. Arango, and D. B. Haidvogel (2000). Water mass pathways between the subtropical and tropical ocean in a climatological simulation of the North Atlantic ocean circulation. Dynamics of Atmospheres and Oceans 32, 331-371.

Mann, H. B. (1945). Non-parametric tests against trend. Econometrica 33, 245-259. 
Mann, M. E., Z. Zhang, S. Rutherford, R. S. Bradley, M. K. Hughes, D. Shindell, C. Ammann, G. Faluvegi, and F. Ni (2009). Global Signatures and Dynamical Origins of the Little Ice Age and Medieval Climate Anomaly. Science 326(November), 1256-1260.

Marshall, G. J. (2003). Trends in the Southern Annular Mode from observations and reanalyses. Journal of Climate 16(24), 4134-4143.

McCarthy, G. D., D. A. Smeed, W. E. Johns, E. Frajka-Williams, B. I. Moat, D. Rayner, M. O. Baringer, C. S. Meinen, J. Collins, and H. L. Bryden (2015). Measuring the Atlantic Meridional Overturning Circulation at $26^{\circ} \mathrm{N}$. Progress in Oceanography 130, 91-111.

McClain, C. R., S. R. Signorini, and J. R. Christian (2002). Subtropical Gyre Variability Observed by Ocean Color Satellites. NASA Scientific and Technical Information Program Office 21161, $1-23$.

McCreary, J. P. and P. Lu (1994). Interaction between the Subtropical and Equatorial Ocean Circulations: The Subtropical Cell. Journal of Physical Oceanography 24(2), 466-497.

Metcalf and Stalcup (1967). Origin of the Atlantic Equatorial Undercurrent. Journal of Geophysical Research 72(20), 4959-4975.

Neale, R. B., C.-c. Chen, P. H. Lauritzen, D. L. Williamson, A. J. Conley, A. K. Smith, M. Mills, and H. Morrison (2010). Description of the NCAR Community Atmosphere Model ( CAM 5 . 0 ). Technical Report April.

Otto-Bliesner, B. L., E. C. Brady, J. Fasullo, A. Jahn, L. Landrum, S. Stevenson, N. Rosenbloom, A. Mai, and G. Strand (2016). Climate variability and change since 850 C.E.: An ensemble approach with the Community Earth System Model (CESM). Bulletin of the American Meteorological Society 97(5), 787-801.

Pereira, J., M. Gabioux, M. Marta-almeida, M. Cirano, A. M. Paiva, and A. L. Aguiar (2014). The Bifurcation of the Western Boundary Current System of the South Atlantic Ocean. Brazilian Journal of Geophysics 32, 241-257.

Peterson, R. and L. Stramma (1991). Upper-level circulation in the South Atlantic Ocean. Progress in Oceanography 26, 1-73.

Polvani, L. M., D. W. Waugh, G. J. P. Correa, and S.-W. Son (2011). Stratospheric Ozone Depletion: The Main Driver of Twentieth-Century Atmospheric Circulation Changes in the Southern Hemisphere. Journal of Climate 24(3), 795-812.

Pontes, G. M., A. S. Gupta, and A. S. Taschetto (2016). Projected changes to South Atlantic boundary currents and confluence region in the CMIP5 models: the role of wind and deep ocean changes. Environmental Research Letters 11(9), 1-9. 
Qiu, B. and S. Chen (2006). Decadal Variability in the Large-Scale Sea Surface Height Field of the South Pacific Ocean : Observations and Causes. Journal of Physical Oceanography 36, 1751-1762.

Qiu, B. and S. Chen (2010). Interannual-to-decadal variability in the bifurcation of the North Equatorial Current off the Philippines. Journal of Physical Oceanography 40, 2525-2538.

Qiu, B. and S. Chen (2012, jan). Multidecadal Sea Level and Gyre Circulation Variability in the Northwestern Tropical Pacific Ocean. Journal of Physical Oceanography 42(1), 193-206.

Qiu, B. and R. Lukas (1996). Seasonal and interannual variability of the North Equatorial Current, the Mindanao Current, and the Kuroshio along the Pacific western boundary. Journal of Geophysical Research 101(C5), 12315-12330.

Qu, T. and R. Lukas (2003). The Bifurcation of the North Equatorial Current in the Pacific*. Journal of Physical Oceanography 33, 5-18.

Rayner, D., J. J.-M. Hirschi, T. Kanzow, W. E. Johns, P. G. Wright, E. Frajka-Williams, H. L. Bryden, C. S. Meinen, M. O. Baringer, J. Marotzke, L. M. Beal, and S. a. Cunningham (2011, sep). Monitoring the Atlantic meridional overturning circulation. Deep Sea Research Part II: Topical Studies in Oceanography 58(17-18), 1744-1753.

Reid, J. L. (1994). On the total geostrophic circulation of th North Atlantic Ocean. Prog. Oceanogr. 33, 1-92.

Richardson, P. L. (2007). Agulhas leakage into the Atlantic estimated with subsurface floats and surface drifters. Deep-Sea Research Part I: Oceanographic Research Papers 54(8), 13611389.

Rodgers, J. L. and W. A. Nicewander (1988). Thirteen Ways to Look at the Correlation Coefficient. The American Statistician 42(1), 59-66.

Rodrigues, R. R., L. M. Rothstein, and M. Wimbush (2007, jan). Seasonal Variability of the South Equatorial Current Bifurcation in the Atlantic Ocean: A Numerical Study. Journal of Physical Oceanography 37(1), 16-30.

Rodrigues, R. R., M. Wimbush, D. R. Watts, L. M. Rothstein, and M. Ollitrault (2010, nov). South Atlantic mass transports obtained from subsurface float and hydrographic data. Journal of Marine Research 68, 819-850.

Roemmich, D. (2007). Super spin in the southern seas. Nature 449, 34-35.

Roemmich, D., J. Gilson, R. Davis, P. Sutton, S. Wijffels, and S. Riser (2007, feb). Decadal Spinup of the South Pacific Subtropical Gyre. Journal of Physical Oceanography 37(2), 162-173. 
Saenko, O. a., J. C. Fyfe, and M. H. England (2005, jul). On the response of the oceanic winddriven circulation to atmospheric CO2 increase. Climate Dynamics 25(4), 415-426.

Schott, F. a., J. Fischer, and L. Stramma (1998). Transports and Pathways of the Upper-Layer Circulation in the Western Tropical Atlantic. Journal of Physical Oceanography 28(10), 19041928.

Schott, F. A., L. Stramma, and J. Fischer (1995). The warm water inflow into the western tropical Atlantic boundary regime, spring 1994 waters of the equatorial circulation. Journal of Geophysical Research 100, $24745-24760$.

Smith, R., P. Jones, B. Briegleb, F. Bryan, G. Danabasoglu, J. Dennis, J. Dukowicz, C. Eden, B. Fox-Kemper, P. Gent, M. Hecht, S. Jayne, M. Jochum, W. Large, K. Lindsay, M. Maltrud, N. Norton, S. Peacock, M. Vertenstein, and S. Yeager (2010). The Parallel Ocean Program (POP) reference manual: Ocean component of the Community Climate System Model (CCSM). Technical report.

Smith, S. W. (1997). The Scientist and Engineer's Guide to Digital Signal Processing (Second ed.).

Speich, S., B. Blanke, and W. Cai (2007, dec). Atlantic meridional overturning circulation and the Southern Hemisphere supergyre. Geophysical Research Letters 34(L23614), 1-5.

Stewart, R. H. (2008). Introduction To Physical Oceanography. Texas A\&M University.

Stramma, L. (1991). Geostrophic transport of the South Equatorial Current in the Atlantic. Journal of Marine Research 49(2), 281-294.

Stramma, L. and M. England (1999). On the water masses and mean circulation of the South Atlantic Ocean. Journal of Geophysical Research 104, 20,863-20,883.

Stramma, L., Y. Ikeda, and R. G. Peterson (1990). Geostrophic Transport in the Brazil Current region north of 20 degrees S. Deep-Sea Research Part A - Oceanographic Research Papers $37(12), 1875-1886$.

Stramma, L. and R. G. Peterson (1990). The South Atlantic Current. Journal of Physical Oceanography $20,846-859$.

Talley, L. D. (2003). Shallow, Intermediate, and Deep Overturning Components of the Global Heat Budget. Journal of Physical Oceanography 33, 530-560.

Thompson, D. W. J. and S. Solomon (2002). Interpretation of recent Southern Hemisphere climate change. Science (New York, N.Y.) 296(5569), 895-899. 
Tokinaga, H. and S.-p. Xie (2011). Weakening of the equatorial Atlantic cold tongue over the past six decades. Nature Geoscience 4, 222-226.

Vellinga, M. and P. Wu (2004). Low-latitude fresh water influence on centennial variability of the thermohaline circulation. J. Climate 17(23), 4498-4511.

Wainer, I., A. Taschetto, B. L. Otto-bliesner, and E. Brady (2004). A Numerical study of the impact of greenhouse gases on the South Atlantic Ocean climatology. Climatic Change 66, 163-189.

Wainer, I. and S. A. Venegas (2002). South Atlantic Multidecadal Variability in the Climate System Model. Journal of Climate 15(12), 1408-1420.

Wang, Q. Y. and D. X. Hu (2006). Bifurcation of the north equatorial current derived from altimetry in the pacific ocean. Journal of Hydrodynamics 18(5), 620-626.

Wang, Z., Y. Lu, F. Dupont, J. W. Loder, C. Hannah, and D. G. Wright (2015). Variability of sea surface height and circulation in the North Atlantic: Forcing mechanisms and linkages. Progress in Oceanography 132, 273-286.

Weijer, W., W. P. M. De Ruijter, and H. A. Dijkstra (2001). Stability of the Atlantic Overturning Circulation: Competition between Bering Strait freshwater flux and Agulhas heat and salt sources. Journal of Physical Oceanography 31(8), 2385-2402.

Weijer, W. and W. D. Ruijter (2002). Response of the Atlantic overturning circulation to South Atlantic sources of buoyancy. Global and Planetary Change 34, 293-311.

Wienders, N., M. Arhan, and H. Mercier (2000). Circulation at the western boundary of the South and Equatorial Atlantic: Exchanges with the ocean interior. Journal of Marine Research 58(6), 1007-1039.

Wilson, W. D., E. Johns, and R. L. Molinari (1994). Upper layer circulation in the western tropical North Atlantic Ocean during August 1989 profiler of NBC transport that has retroflected from the transport returning eddy with transport lies a small portion of the observed NEC transport enters the Caribbea. North 99(C11), 22,513-22,523.

Witter, D. L. and A. L. Gordon (1999). Interannual variability of South Atlantic circulation from 4 years of TOPEX/POSEIDON satellite altimeter observations. Journal of Geophysical Research 104(C9), 20,927-20,948.

Wu, L., W. Cai, L. Zhang, H. Nakamura, A. Timmermann, T. Joyce, M. J. McPhaden, M. Alexander, B. Qiu, M. Visbeck, P. Chang, and B. Giese (2012, jan). Enhanced warming over the global subtropical western boundary currents. Nature Climate Change 2(3), 161-166. 
Yamagami, Y. and T. Tozuka (2015, dec). Interannual variability of South Equatorial Current bifurcation and western boundary currents along the Madagascar coast. Journal of Geophysical Research: Oceans 120(12), 8551-8570.

Zhai, F., Dunxin Hu, Qingye Wang, and F. Wang (2014). Long-term trend of Pacific South Equatorial Current bifurcation over 1950-2010. Geophysical Research Letters 41, 3172-3180.

Zhang, D., M. J. McPhaden, and W. E. Johns (2003). Observational Evidence for Flow between the Subtropical and Tropical Atlantic: The Atlantic Subtropical Cells. Journal of Physical Oceanography 33, 1783-1797.

Zhang, D., R. Msadek, M. J. McPhaden, and T. Delworth (2011, apr). Multidecadal variability of the North Brazil Current and its connection to the Atlantic meridional overturning circulation. Journal of Geophysical Research 116(C4), C04012.

Zhang, X., J. a. Church, S. M. Platten, and D. Monselesan (2013, aug). Projection of subtropical gyre circulation and associated sea level changes in the Pacific based on CMIP3 climate models. Climate Dynamics 43(1-2), 131-144. 


\section{Appendix I - Resumo Informal}

Este estudo investiga a ocorrência de mudanças na circulação do giro subtropical do oceano Atlântico Sul (AS). Essa circulação é primariamente regida pelo vento e ocorre na camada superior do oceano, girando no sentido anti-horário (esquema na Figura 29).

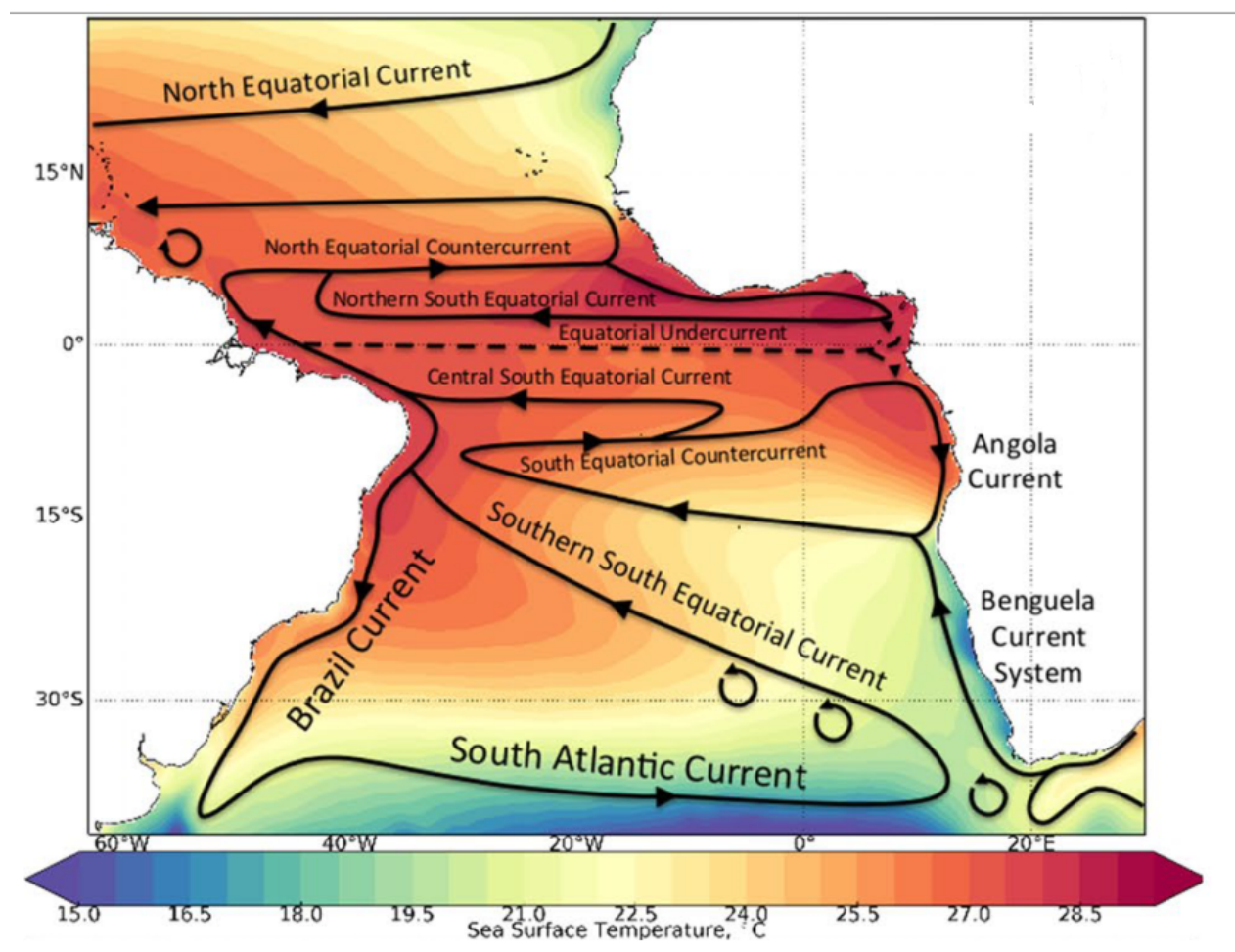

Figura 29 | Representação esquemática do Atlântico Sul e da região equatorial. | Contornos em preto representam as correntes superficiais e cores de fundo, a Temperatura da Superfície do Mar (Sea Surface Temperature). O giro subtropical do AS é formado por parte do sistema de correntes da Benguela na borda leste (Benguela Current System), o ramo sul da Corrente Sul Equatorial (CSEs) na borda nordeste/norte (southern South Equatorial Current), a Corrente do Brasil (CB) na borda oeste fluindo para sul (Brazil Current) e a Corrente do Atlântico Sul fluindo para leste no limite inferior (South Atlantic Current). Extraído de Cabos et al. (2016).

No Atlântico Sul, a circulação do giro subtropical é acoplada à circulação que é regida por diferenças de densidade entre as massas de água (por variação de temperatura e salinidade - a circulação termohalina). Juntos, esses dois regimes de circulação compõe a Circulação de Revolvimento Meridional (CRM), que tem proporção global, conectando todas as bacias oceânicas (Atlântico, Índico e Pacífico).

O oceano Atlântico é o palco principal onde ocorrem os processos mais importantes relativos à CRM. O acoplamento da circulação do giro subtropical do AS com a CRM ocorre principalmente através de um braço da CRM que passa na camada superior do AS, vindo lá da borda sudeste da bacia oceânica e pegando carona no giro subtropical pelo contorno da sua borda nordeste-norte, a partir de onde segue em direção ao equador, rumo ao Hemisfério Norte.

Portanto, como no AS a CRM está embutida na circulação do giro subtropical, podendo influenciá-la, este fator externo deve ser levado em consideração ao se estudar a variabilidade do giro. Para isso, a sua borda norte é investigada à parte, e definida como o ponto em que a corrente fluindo nesse limite superior do giro se aproxima da costa da América do Sul e bifurca 
para norte e para sul. Sendo que a porção de águas que vai para norte segue em parte com o braço da CRM, enquanto a porção de águas que vai para sul recircula no giro subtropical.

As ferramentas usadas para investigar esses fatores são dois conjuntos de dados: X1 (o qual cobre o período de 1948 à 2015) e X2 (que cobre o período desde 850 até 2005). Esses conjuntos de dados representam informações sobre a variação temporal de indicadores do estado de circulação do Atlântico Sul, tais como o campo espacial (domínio latitude versus longitude e dependendo da variável, profundidade também) das velocidades, da altura do mar e do vento soprando sobre o oceano. Esses dados são gerados por modelos numéricos que simulam o comportamento do oceano.

Em relação à dinâmica geral do giro subtropical, esses dados mostraram que houve mudanças significativas na circulação do AS, as quais se iniciaram principalmente após os anos 70/80 (visível nos resultados de X1), e que quando vistas da perspectiva temporal mais ampla de X2, assumem proporções imprescindíveis em relação à toda linha de tempo do último milênio. Mais especificamente, essas mudanças reveladas apontam para uma aceleração da circulação do giro, além de uma migração de toda a estrutura do giro para sul, em direção ao pólo.

A borda norte do giro, representada pela bifurcação, também migra para sul.

Enquanto essa migração para sul da bifurcação está de acordo com a migração para sul de todo o giro, é contra-intuitiva em relação à aceleração da circulação anti-horária — pois o aumento do transporte de águas fluindo para sul com a circulação do giro faria com que a bifurcação da corrente ocorresse cada vez em posições mais a norte.

No entanto, ao investigar também o transporte de águas que vão para norte após a corrente bifurcar, observa-se que este aumenta em proporção muito maior que o transporte para sul — nos fornecendo uma explicação plausível do porque a bifurcação também migra para sul.

Portanto as conclusões finais são:

- A circulação anti-horária do giro subtropical do AS fica mais intensa/acelerada ao passo que a estrutura espacial do giro se desloca em direção ao pólo (para sul);

- A borda norte do giro subtropical (definida pela bifurcação) também migra para sul;

- A migração pra sul da bifurcação está de acordo com a migração para sul de todo o giro; mas contra a aceleração da sua circulação. No entanto, parece estar associada ao aumento substancial do transporte de águas para norte, que 'empurra' a bifurcação para sul.

A circulação dos giros subtropicais está intimamente ligada à variabilidade climática global e pode, por exemplo, impactar e modular o clima dos continentes arredores e influenciar processos importantes como o sequestro de carbono para o oceano profundo (que ajuda a diminuir a quantidade de $\mathrm{CO}_{2}$ na atmosfera). Estudos da variabilidade da circulação do giro, portanto, podem nos fornecer pistas e informações acerca desses assuntos.

Essas descobertas referentes à mudanças na circulação do giro subtropical e em outras componentes da circulação do oceano AS, representam um potencial cenário em vista às mudanças climáticas globais recorrentes, em consequência do aumento dos gases do efeito estufa e da influência da atividade humana no aquecimento global. 